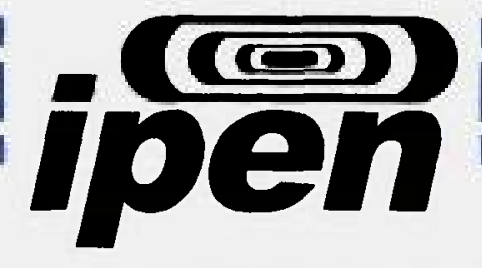

AUTARQUIA ASSOCIADA A UNIVERSIDADE DE SÃo PAULO

ESTUDO DAS PROPRIEDADES DO AÇÚCAR LIQQUIDO INVERTIDO PROCESSADO COM RADIAÇÃO GAMA E FEIXE DE ELÉTRONS

\author{
PRISCILLA PODADERA
}

Tese apresentada como parte dos requisitos para obtenção do Grau de Doutor em Ciências na Área de Tecnologia Nuclear - Aplicações.

Orientadora:

Dra. Susy Frey Sabato

São Paulo 


\section{ipen}

INSTITUTO DE PESQUISAS ENERGÉTICAS E NUCLEARES

Autarquia associada à Universidade de São Paulo

Estudo das propriedades do açúcar líquido invertido processado com radiação gama e feixe de elétrons

\section{Priscilla Podadera}

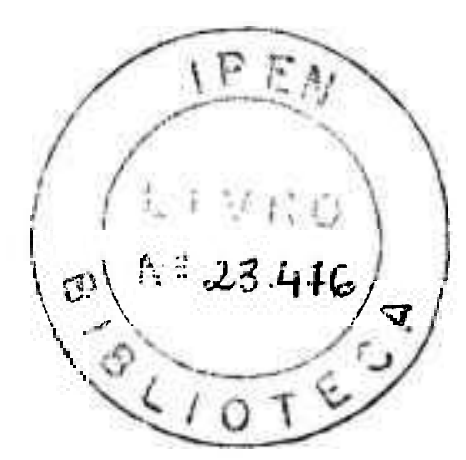

Tese apresentada como parte dos requisitos para obtenção do Grau de Doutor em Ciências na Área de Tecnologia Nuclear-Aplicações.

Orientador:

Dra. Susy Frey Sabato 


\section{ipen}

INSTITUTO DE PESQUISAS ENERGÉTICAS E NUCLEARES

Autarquia associada à Universidade de São Paulo

Estudo das propriedades do açúcar líquido invertido processado com radiação gama e feixe de elétrons

\section{Priscilla Podadera}

Tese apresentada como parte dos requisitos para obtenção do Grau de Doutor em Ciências na Área de Tecnologia Nuclear-A plicações.

Orientador:

Dra. Susy Frey Sabato 
À minha mãe pelo amor, dedicação e incentivo. 


\section{Agradecimentos}

À Dra Susy Frey Sabato pela orientação, apoio e confiança durante todas as etapas deste trabalho.

À Dra Maria Helena de Oliveira Sampa pelo apoio e sugestões.

Ao Instituto de Pesquisas Energéticas e Nucleares-IPEN.

Ao Senai Mario Amato-SBC por fornecer a infra-estrutura dos laboratórios de análise de alimentos e microbiologia para a realização das análises.

À empresa Da Barra pelo fornecimento das amostras de açúcar invertido, sem as quais não seria possível realizar o estudo.

À Dra. Maria Lurdes Felsner pelo acompanhamento, ajuda e sugestões.

À Elizabeth S. R. Somessari e Carlos Gaia da Silveira pelas dúvidas esclarecidas e pela irradiação das amostras.

À Dra. Maria Tereza Pepe Razzolini pela ajuda nas análises microbiológicas.

À Claudia Regina Nolla e Marco Cardoso da Silva pela ajuda durante a etapa de análise sensorial.

Aos funcionários da Divisão de Pós-Graduação pelas informações e orientações prestadas.

Aos funcionários e alunos do Centro de Tecnologia das Radiações que contribuíram na análise sensorial do açúcar invertido.

Meu agradecimento a todos que me acompanharam ao longo dessa jornada e que direta ou indiretamente cooperaram na realização deste trabalho. 


\title{
ESTUDO DAS PROPRIEDADES DO ACÚCAR LÍQUDO INVERTIDO PROCESSADO COM RADIAÇÃO GAMA E FEIXE DE ELÉTRONS
}

\author{
Priscilla Podadera
}

\begin{abstract}
RESUMO
O Brasil ocupa posição de destaque no mercado de açúcar a granel e consumo elevado deste ingrediente na forma liquida, em especial pelas indústrias de bebidas e alimentos. $\mathrm{O}$ açúcar líquido apresenta vantagens em relação ao açúcar a granel como facilidade do manuseio e dosagem, espaço reduzido para a armazenagem, redução das perdas, custos e mão-de-obra, melhora na sanitização e grande variação possível nas proporções de diferentes misturas de açúcares. $O$ açúcar líquido invertido é uma solução de sacarose, glicose e frutose em água e recebe esse nome porque durante a sua produção há a inversão do poder óptico de rotação da solução. No processo produtivo do açúcar invertido existem alguns pontos que podem gerar a contaminação por microrganismos, dessa forma torna-se importante o desenvolvimento de técnicas que propiciem a sanitização eficiente desta matéria-prima. Este trabalho estudou duas técnicas alternativas de controle microbiano: a radiação gama com fonte de cobalto- 60 e a radiação com feixe de elétrons. $\mathrm{O}$ estudo foi conduzido nas doses de 5,10,20,30 e 50 kGy. O teor de sacarose apresentou decréscimo com a radiação indicando que ocorreu a quebra da ligação glicosídica com a formação de glicose e frutose, gerando o aumento do teor de sólidos solúveis. Ocorreu a formação de compostos ácidos, confirmado pela redução de $\mathrm{pH}$, que foi proporcional ao aumento da dose de radiação. As maiores doses provocaram alterações na cor do xarope pela formação de polímeros com cadeia molecular longa. A viscosidade nas amostras irradiadas com radiação gama aumentou em relação ao controle, indicando a prevalência de polimerização das moléculas, enquanto que na radiação com feixe de elétrons a polimerização foi observada somente na amostra que recebeu a dose de $50 \mathrm{kGy}$. $\mathrm{Na}$ análise sensorial, os julgadores apontaram diferença significativa (5\%) no sabor entre o controle e as amostras irradiadas com $5 \mathrm{kGy}$, nas duas técnicas de processamento. Não foi possível identificar o efeito da radiação gama no controle de bolores e leveduras.
\end{abstract}

Palavras-chaves: Açúcar líquido invertido; radiação gama; radiação com feixe de elétrons; viscosidade; hidroximetilfurfural; glicose; frutose; sacarose; propriedades fisicoquímicas; bolores; leveduras. 


\title{
STUDY OF THE PROPERTIES OF INVERTED LIQUID SUGAR PROCESSED WITH GAMMA RADIATION AND ELECTRON BEAM
}

\author{
Priscilla Podadera
}

\begin{abstract}
Brazil occupies position of prominence in the sugar market and high consumption of this ingredient in the liquid form, in special for the beverages and food industries. The liquid sugar presents advantages in relation to the bulk granulated system such as easiness of the handling and dosage, reduced space for the storage, reduction of the losses, costs and hand of workmanship, improvement of the sanitizing and great possible variation in the ratios of different mixtures of sugars. The inverted liquid sugar is a solution of sucrose, glucose and fructose in water. This ingredient receives this name because during its production it has an inversion of the optic power of rotation of the solution. In the productive process of the inverted sugar some points occur that can generate contamination by microorganisms, so its become important the development of techniques that propitiate the efficient sanitizing of this raw material. This work aims at to consider two alternative techniques of microbiologic control: gamma radiation with source of cobalto-60 and radiation with electron beam. The study was lead in the doses of $5,10,20,30$ and $50 \mathrm{kGy}$. Concentration of sucrose presented in syrup decreased with the radiation indicating the scission of glicosídic linkage in addition with the glucose and fructose formation, generating the increase in solids soluble. The acid compounds formation occurred, confirmed by the reduction of $\mathrm{pH}$, that it was proportional with the increase of the radiation dose. The biggest doses had provoked change of color in the syrup by the long molecular chain polymers formation. Viscosity in the samples processed by gamma radiation increased in relation to the control, indicating the prevalence of polymerization of molecules, whereas in the radiation with electron beam the polymerization was only observed in the sample that received the dose of $50 \mathrm{kGy}$. In the sensorial analysis, the judges had pointed significant difference $(5 \%)$ in the flavor among control and the samples radiated with $5 \mathrm{kGy}$ in the two techniques of processing. The alterations provoked for the irradiation had not been enough to provide significant changes in the inverted sugar, even in the highest dose of $50 \mathrm{kGy}$. It was not possible to identify the effect of gamma radiation in the control of molds and yeasts.
\end{abstract}

Key-words: invert syrup; gamma radiation; electron beam radiation; viscosity; hydroxymethyfurfural; glucose; fructose; sucrose; physical-chemical properties; molds; yeasts. 


\section{SUMARIO}

Página

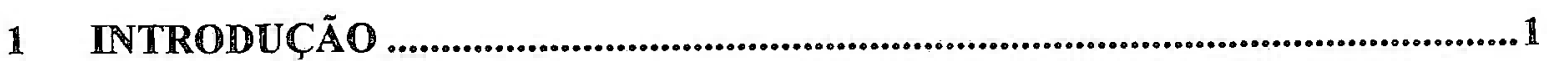

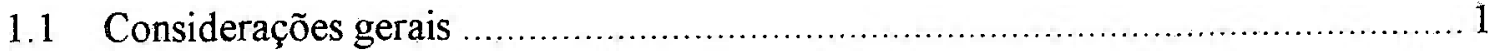

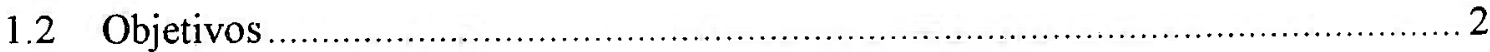

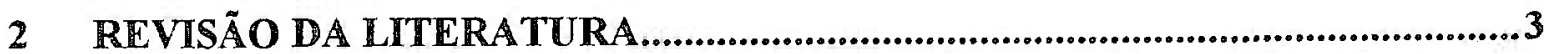

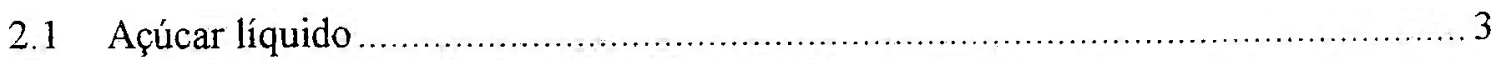

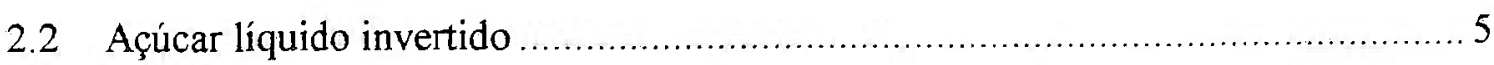

2.3 Produção do açúcar líquido invertido .................................................... 7

2.4 Contaminação microbiana do açúcar líquido............................................ 12

2.5 Propriedades físico-químicas do açúcar líquido....................................... 14

2.6 Aplicação do açúcar líquido invertido .................................................. 19

2.7 Processamento de alimentos por irradiação .............................................. 21

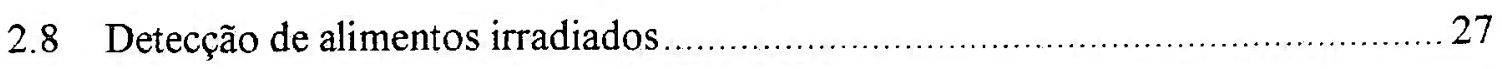

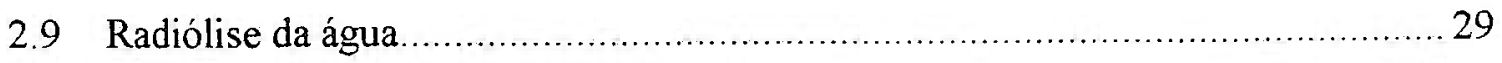

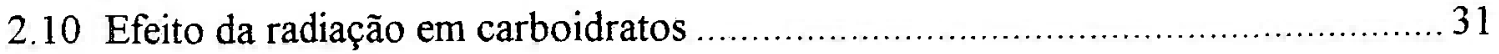

2.11 Radiação gama e por feixe de elétron.................................................... 36

2.12 Legislação para alimentos irradiados ................................................... 40

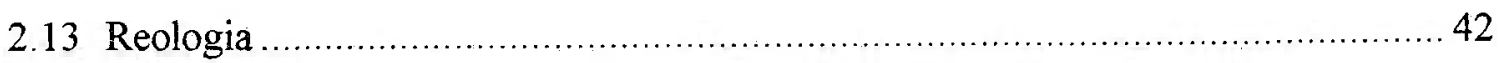

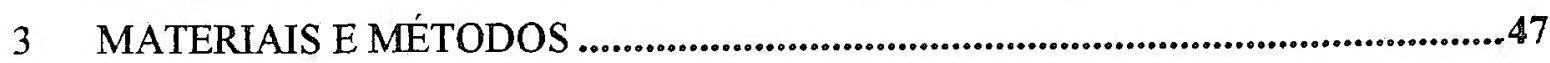

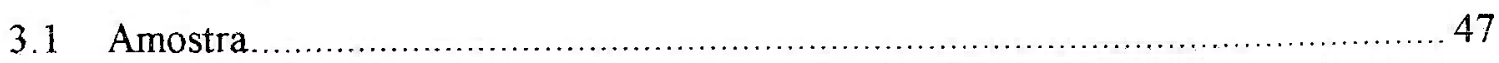

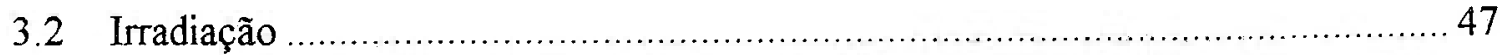

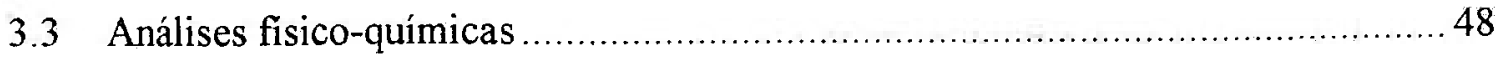

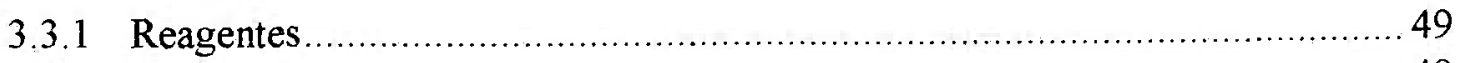

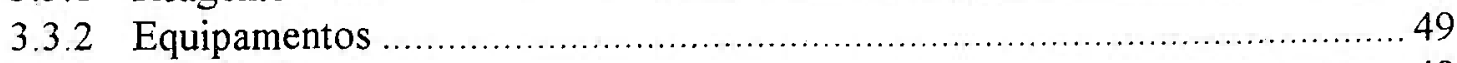

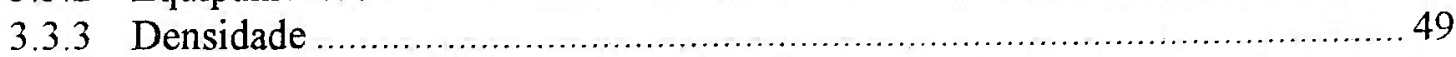

3.3.4 Sólidos solúveis ("Brix) e índice de refração.......................................... 49

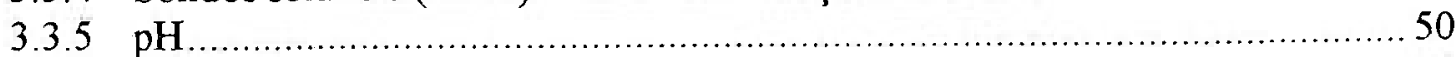

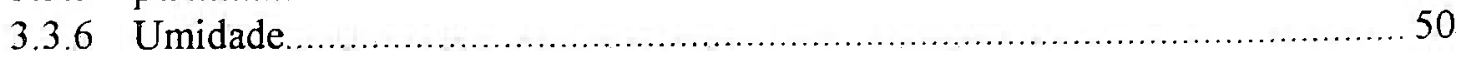




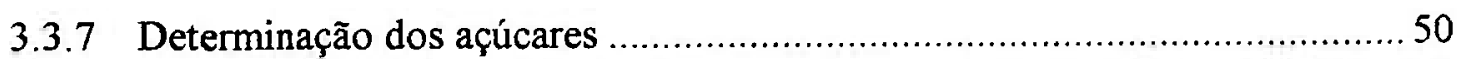

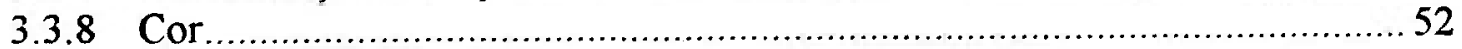

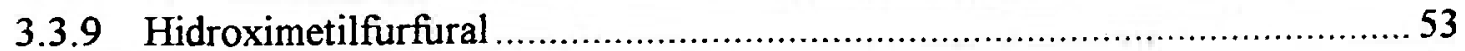

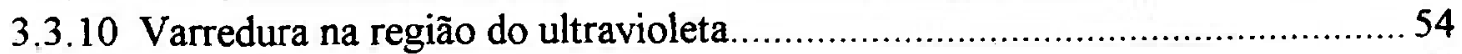

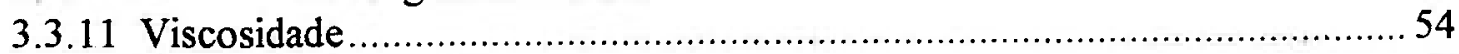

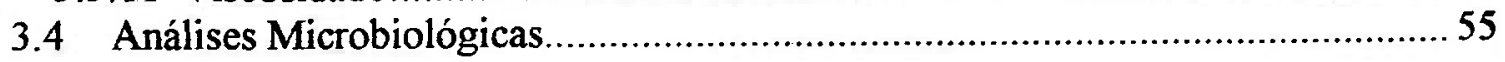

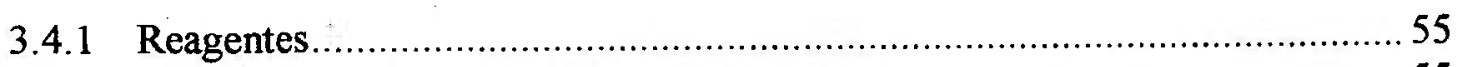

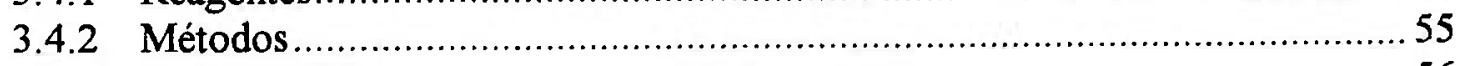

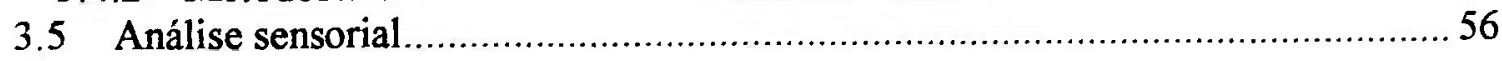

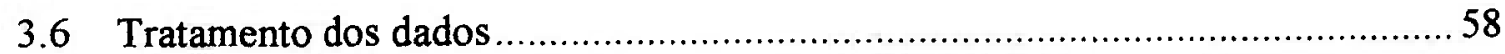

4 RESULTADOS E DISCUSSÃO.........................................................................59

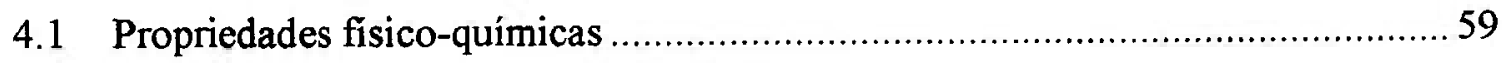

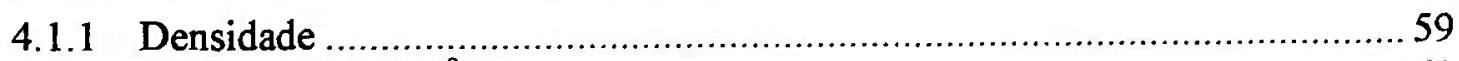

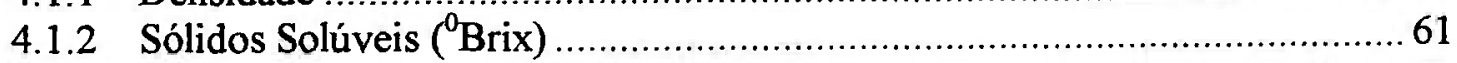

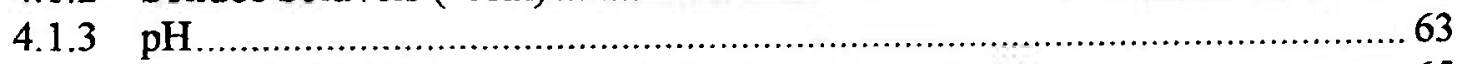

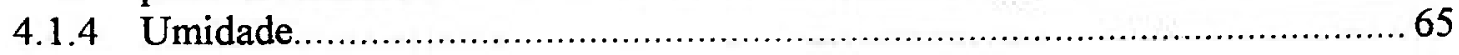

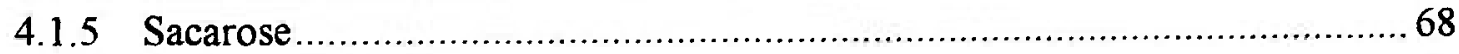

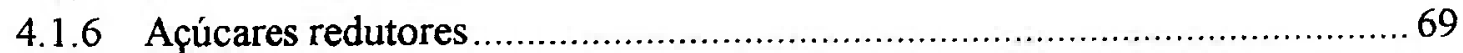

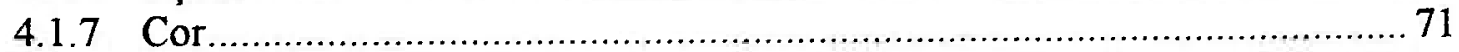

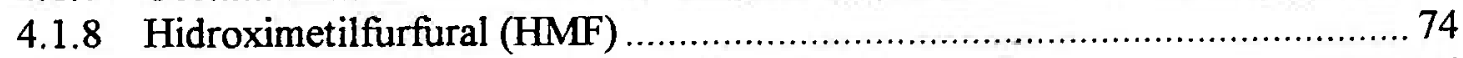

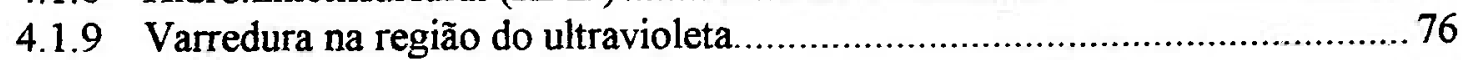

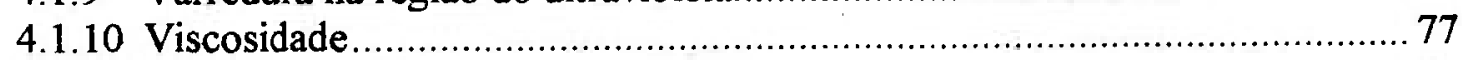

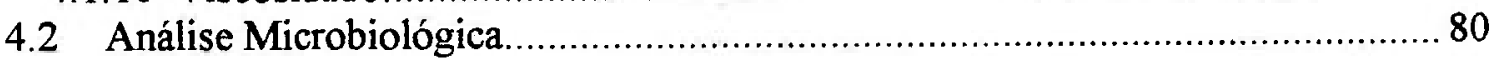

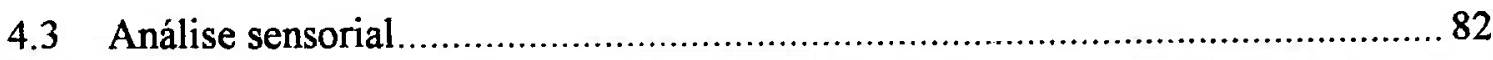

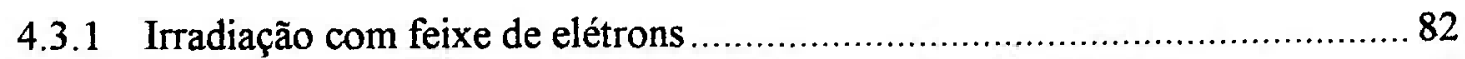

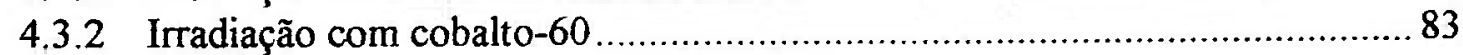

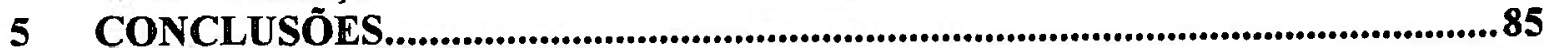

REFERÊNCIAS BIBLIOGRÁFICAS.....................................................................91 


\section{INTRODUGÃO}

\subsection{Considerações gerais}

O Brasil ocupa posição de destaque no mercado de açúcar a granel. É o maior produtor mundial. Em 2005, sua produção atingiu 420 milhões de toneladas e, em 2004, foi - maior exportador com 129 milhões de toneladas (FAOSTAT, 2006). Com o desenvolvimento da indústria de bebidas, as usinas de açúcar a fim de agregar valor ao produto e atender a este mercado consumidor mais exigente começaram a produzir açúcar na forma líquida.

O consumo desse ingrediente no Brasil é elevado. Dados de 2004 indicam que a produção foi de $600 \mathrm{mil}$ toneladas/ano. Apesar do grande interesse neste produto, a literatura é escassa e muitas vezes não há a diferenciação entre os tipos de xarope existentes no mercado. $O$ açúcar líquido é uma solução de açúcar em água. $O$ açúcar presente pode ser glicose, frutose, sacarose, uma mistura de glicose enriquecida com frutose ou ainda uma mistura de três açúcares: glicose, frutose e sacarose, neste caso o xarope recebe o nome de açúcar líquido invertido, que é muito usado na indústria de alimentos, bebidas e farmacêutica e foi o objeto de estudo desta tese.

O açúcar invertido pode ser produzido através de três métodos: meio ácido a quente, resina de tróca catiônica fortemente ácida ou através da enzima invertase. A técnica mais utilizada é através da adição de ácido em uma solução de sacarose. Quando a inversão é realizada diretamente no alimento, como por exemplo, na produção de centros macios em balas, utiliza-se o método enzimático.

O açúcar invertido recebe esse nome, pois ocorre a inversão do poder óptico da solução com a adição do ácido. O ácido proporciona a quebra da ligação glicosídica da sacarose com a formação de glicose e frutose. Enquanto a sacarose em solução tem rotação específica positiva, a glicose e a frutose juntas apresentam rotação específica negativa.

Durante o processo de produção do açúcar invertido ocorrem alguns pontos de contaminação por microrganismos. A fase crítica ocorre durante a armazenagem. $\mathrm{O}$ 
contato com a umidade presente no ar que fica acima da superficie do xarope pode diluir a solução propiciando o crescimento de bolores e leveduras. $\mathrm{Na}$ literatura encontra-se descrito apenas um método de controle de crescimento de microrganismos: a radiação ultravioleta, porém esta técnica apresenta algumas desvantagens como alteração do $\mathrm{pH}$, da cor e do sabor do xarope.

\subsection{Objetivos}

$\mathrm{Na}$ literatura, os relatos sobre as modificações que a radiação gama e por feixe de elétrons podem provocar no açúcar líquido invertido são escassos. $O$ objetivo deste trabalho foi identificar e quantificar as alterações no açúcar invertido irradiado em diferentes doses. $O$ estudo foi desenvolvido nas etapas descritas a seguir.

- Identificar e quantificar as alterações nas propriedades físico-químicas do açúcar líquido invertido irradiado com fonte de cobalto-60 nas doses de $5,10,20,30$ e 50 kGy, comparando com o controle;

- Identificar e quantificar as alterações nas propriedades físico-químicas do açúcar líquido invertido irradiado com feixe de elétrons nas doses de 5, 10, 20, 30 e 50 kGy, comparando com o controle;

- Verificar o comportamento microbiológico, para bolores e leveduras, do açúcar líquido invertido irradiado nas doses de 5, 10, 20, 30 e $50 \mathrm{kGy}$ com fonte de cobalto-60, durante 9,5 meses;

- Identificar mudanças no sabor do açúcar líquido irradiado com dose de $5 \mathrm{kGy}$ em fonte de cobalto-60, através de análise sensorial (teste triangular);

- Identificar mudanças no sabor do açúcar líquido irradiado com dose de $5 \mathrm{kGy}$ com feixe de elétrons, através de análise sensorial (teste triangular). 


\section{REVISÃO DA LITERATURA}

\subsection{Açúcar líquido}

O Brasil é o maior produtor mundial de açúcar a granel; em 2005, sua produção atingiu 420 milhões de toneladas e, em 2004, foi o maior exportador com 129 milhões de toneladas (FAOSTAT, 2006). As usinas de açúcar a fim de agregar valor ao produto e atender ao mercado consumidor mais exigente começaram a produzir açúcar na forma líquida. Em 2004, a produção anual de açúcar líquido foi de 600 mil toneladas/ano (dados fornecido pela empresa DULCINI).

O açúcar líquido é uma solução de açúcar em água, podendo ser constituído apenas por um açúcar ou uma mistura de dois ou mais açúcares. $O$ açúcar líquido pode ser. formado por sacarose, glicose ou frutose, ou ainda uma mistura destes três açúcares e finalmente por glicose enriquecida com frutose (Davis \& Prince, 1955; Marignetti \& Mantovani, 1979/80).

$\mathrm{O}$ açúcar líquido de sacarose é produzido a partir da dissolução do açúcar refinado granulado em água até obter uma solução de $67,5^{\circ}$ Brix. Caso o açúcar usado não seja branco, a solução pode adquirir uma coloração amarelada obrigando a passagem do produto em carvão vegetal (Davis \& Prince, 1955; Marignetti \& Mantovani, 1979/80).

O açúcar líquido contendo frutose apresenta qualidades como doçura, solubilidade e labilidade ao calor que contribuem para o aumento do interesse comercial por este produto. A sua produção pode ser realizada por hidrólise da inulina, por inversão da sacarose ou ainda pela hidrólise do amido à glicose, com subseqüente isomerização e separação (Marignetti \& Mantovani, 1979/80).

O xarope de glicose ou xarope de milho é um produto resultante da hidrólise ácida do amido presente no milho. Os xaropes de glicose são essencialmente usados na 
indústria como ingredientes de produtos alimentícios. O custo da glicose em solução é menor que dos xaropes de sacarose e invertido e previne a cristalização da sacarose em doces (Marignetti \& Mantovani, 1979/80; Paschoalim, 1990).

O xarope de milho enriquecido com frutose, também denominado de isoglicose, é obtido pela isomerase da glicose proveniente do amido do milho. A vantagem desse xarope é que ele é tão doce quanto o açúcar refinado, permitindo o uso em menores quantidades, reduzindo os custos de produção. Seu uso propicia o escurecimento mais fácil de pães e melhora a textura dos alimentos. O conteúdo típico deste xarope é $50 \%$ de glicose e $42 \%$ de frutose, a quantidade deste último açúcar pode variar até $55 \%$ (Marignetti \& Mantovani, 1979/80; Sweet but not so innocent, 2006; HFCS facts, 2006).

$\mathrm{O}$ açúcar líquido contendo uma mistura em diferentes proporções de frutose, glicose e sacarose é conhecido como invertido. Este ingrediente de uma infinidade de produtos foi o objeto de estudo desta tese (Davis \& Prince, 1955; Marignetti \& Mantovani, 1979/80; Brasil, 2005).

$\mathrm{O}$ primeiro açúcar líquido que se tem notícia remonta à época de Napoleão. Era constituido de glicose e foi introduzido junto com a manufatura industrial (Marignetti \& Mantovani, 1979/80).

Este ingrediente passou a ser produzido em escala industrial a partir de 1927 e a sua demanda cresceu rapidamente à medida que as aplicações na indústria de alimentos e bebidas cresciam. A indústria de bebidas deu ao açúcar líquido uma posição de destaque no mercado (Marignetti \& Mantovani, 1979/80).

Os açúcares na forma líquida apresentam vantagens em relação ao açúcar a granel como facilidade do manuseio e dosagem, espaço reduzido para a armazenagem, redução das perdas, custos e mão de obra, melhora na sanitização, além das propriedades microbiológicas conhecidas e da grande variação possível nas proporções de diferentes misturas de açúcares. As desvantagens deste produto são: a baixa solubilidade da sacarose, a susceptibilidade ao ataque microbiano e a necessidade de equipamentos especiais para armazenagem e manuseio (Davis \& Prince, 1955; Marignetti \& Mantovani, 1979/80; Bruder \& Moroz, 1981).

Os açúcares líquidos têm aplicações variadas. São utilizados como matériaprima em biscoitos, produtos assados e de confeitaria, enlatados, bebidas, como: 
aguardente, refrigerantes, cervejas e sucos de frutas, laticínios, sorvetes, manteiga e indústria de frutas geladas. A baixa viscosidade aliada às propriedades umectantes permite o emprego desta matéria-prima em geléias, bolos, produtos contendo gelatina e doces aerados. $\mathrm{O}$ uso extenso do açúcar líquido em bebidas deve-se ao seu baixo conteúdo de saponinas, a máxima concentração permitida em bebidas é de 2 ppm (Davis \& Prince, 1955; Marignetti \& Mantovani, 1979/80).

\subsection{Açúcar líquido invertido}

A literatura é escassa no relato de estudos sobre o açúcar liquido e muitas vezes, não há a diferenciação entre o açúcar constituído apenas de sacarose e o açúcar líquido invertido. $\mathrm{O}$ desenvolvimento das indústrias de alimentos e bebidas, que são as principais consumidoras desta matéria prima, impulsionou o interesse por este produto. (Junk et al., 1947; Davis \& Prince, 1955).

O açúcar invertido apresenta como concorrentes o xarope de milho e o xarope de milho enriquecido com frutose, que apresentam características semelhantes ao açúcar invertido e custos menores. As misturas de açúcares presentes no xarope invertido deram ao produto características únicas como: alta higroscopicidade, resistência a cristalização e doçura que permitiram a longa vida deste produto no mercado.

$\mathrm{O}$ açúcar invertido é produzido pela hidrólise da molécula de sacarose em solução. A quebra da sacarose ocorre na ligação entre o núcleo de piranose e furanose, com a liberação de uma molécula de glicose e uma de frutose. Nesta reação, ocorre a absorção de água. As moléculas resultantes de água, de glicose e de frutose aumentam o peso, a partir da sacarose que foram produzidos, em 5,26\% (Marignetti \& Mantovani, 1979/80). A reação de hidrólise está representada na FIG. 1. 


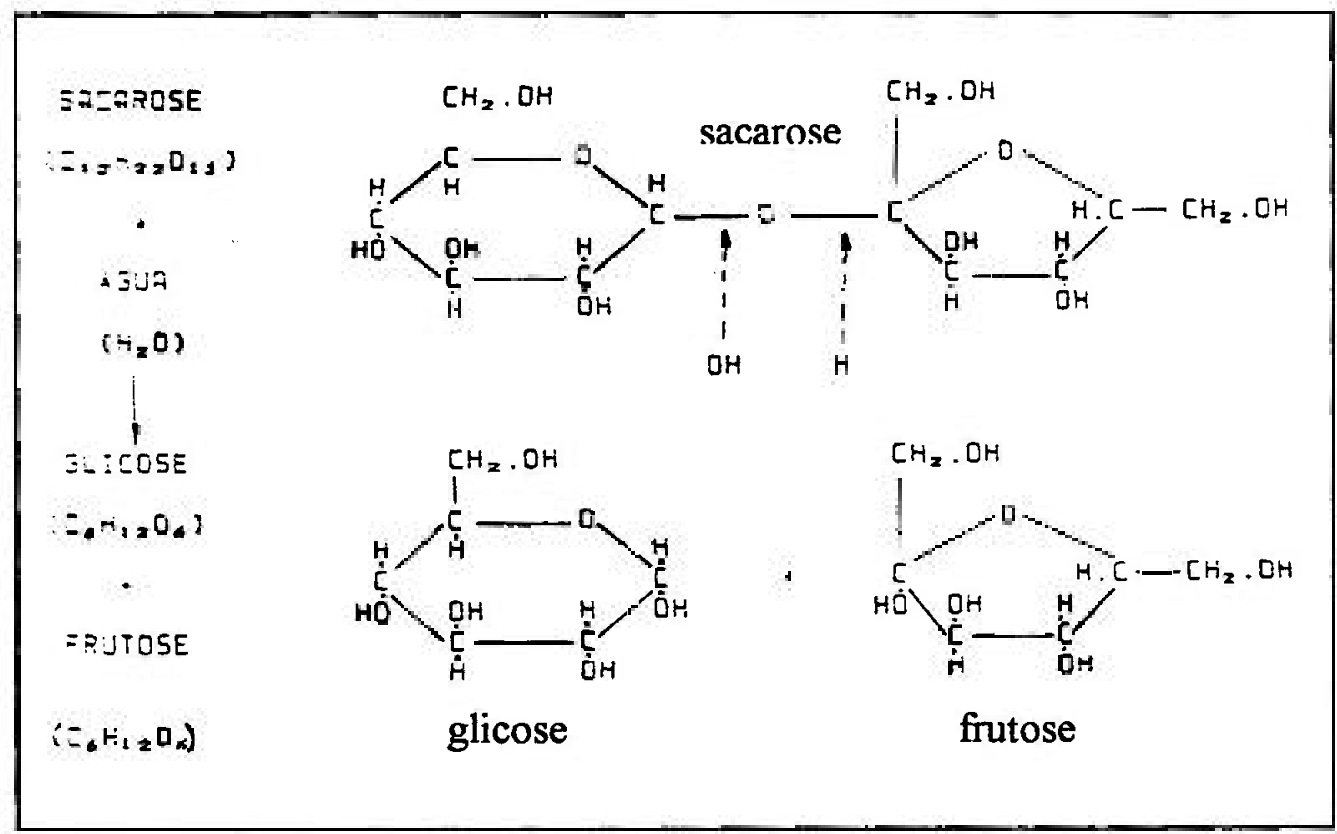

FIGURA 1 - Reação de hidrölise da sacarose com a formação de glicose e frutose. Fonte: Paschoalim, 1990.

A mistura de açúcares obtida após a inversão é denominada de açúcar líquido invertido, pois ocorre uma inversão do poder óptico rotatório da solução. Um feixe de luz polarizada ao atravessar uma solução de sacarose pura desvia o feixe de luz para a direita, após a hidrólise a solução equimolar de glicose e frutose obtida, passa a desviar o feixe de luz para a esquerda. Uma solução contendo $100 \mathrm{~g}$ de sacarose diluída em $100 \mathrm{~mL}$ de água tem rotação específica de $[\alpha]_{D}^{20}+66,5$. Após a inversão total, a rotação específica da solução passa a ser de $[\alpha]_{D}^{0}-39,6$, que corresponde a soma da rotação específica da glicose: $[\alpha]_{D}^{20}+52,7$ e da frutose: $[\alpha]_{D}^{o}-92,3$, como pode ser observado na FIG. 2 (Shallenberger $\&$ Birch, 1975; Paschoalim, 1990; Chemello, 2006).

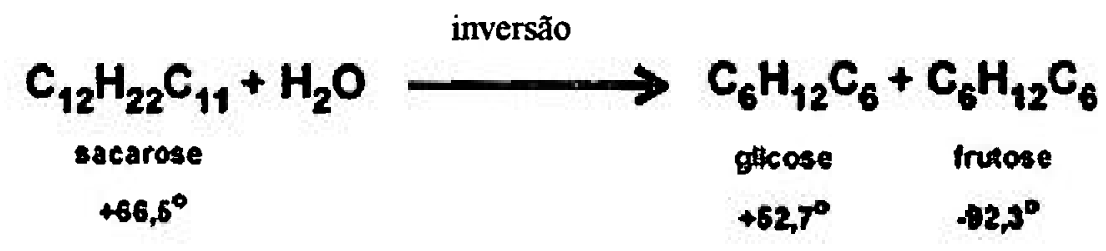

FIGURA 2 - Hidólise da solução de sacarose com a formação dos produtos: glicose e frutose. Fonte: Chemello, 2006.

A inversão da sacarose é uma estratégia usada na fabricação de bombons com recheio pastoso. Durante o processo de fabricação, o bombom é recheado com uma pasta de sacarose, água e invertase. Até a sua venda, ocorrerá, no interior do bombom, a inversão da sacarose com formação de uma mistura de glicose e frutose. Esses açúcares de seis 
carbonos são mais solúveis em água do que o de doze carbonos e, então, como conseqüência de sua dissolução na água, existente na pasta, a mistura passa a ser mais doce e ter uma consistência líquida. A doçura relativa da mistura de iguais proporções dos dois monossacarídeos, glicose e frutose, é maior que a sacarose (Chemello, 2006).

\subsection{Produção do açúcar líquido invertido}

A inversão da sacarose para produção do açúcar invertido pode ser realizada em meio ácido a quente, em resina de troca catiônica fortemente ácida ou por ação da enzima invertase (Moroz et al., 1973; Marignetti \& Mantovani, 1979/80). A inversão pode ser realizada diretamente em uma solução de sacarose ou em alimentos contendo este açúcar (Rodrigues et al., 2000).

As especificações do açúcar invertido permitem relativa flexibilidade na escolha da matéria-prima para a sua fabricação. Algumas matérias-primas que podem ser utilizadas como alternativa para a sacarose são melado de cana e beterraba, tâmaras, uvas e xarope de milho por isomerização enzimática (Moroz et al., 1973; Marignetti \& Mantovani, 1979/80).

A produção do açúcar líquido invertido, na Irlanda, iniciou-se em 1951. O açúcar de cana bruto era fundido e filtrado. O processo de inversão ocorria com a adição de ácido clorídrico, a reação tinha fim com a adição de hidróxido de sódio. O liquor invertido era, então, misturado com uma porção de açúcar não invertido e passado em carbono ativado para eliminação cor (Marignetti \& Mantovani, 1979/80).

Desde então novas técnicas para a fabricação do açúcar líquido invertido têm sido descritas na literatura. Algumas delas estão apresentadas a seguir.

A hidrólise ácida é o método mais antigo e mais econômico para produzir o açúcar invertido a partir da sacarose, o ácido age como um catalisador da reação. No Brasil, a quase totalidade do açúcar invertido é produzido por este processo, de forma descontínua (Paschoalim, 1990). Os principais fatores que controlam a inversão são: a concentração dos reagentes, a concentração de ácido, a temperatura e o tempo de reação. A velocidade de inversão aumenta com a elevação da temperatura e redução do $\mathrm{pH}$, que podem gerar um produto altamente colorido (Rodrigues et al., 2000). Os ácidos têm eficiência diferente na taxa de inversão, portanto a escolha correta é um aspecto importante. Ao ácido clorídrico foi atribuído o poder de inversão de 100, para o ácido sulfúrico o poder de inversão é de 53,6 e para o ácido fosfórico de 6,21. O poder de 
inversão é a relação entre a constante de inversão do ácido em questão e o ácido cloridrico a $25{ }^{\circ} \mathrm{C}$, multiplicado por 100 (Moroz et al., 1973; Bruder \& Moroz, 1981).

A produção de açúcar parcialmente invertido, em larga escala, muitas vezes não permite a parada do processo na taxa de inversão determinada. Nesta situação, mistura-se de 90 a $95 \%$ do açúcar invertido com um xarope não invertido, para se obter o grau de inversão desejado (Junk et al., 1947).

A matéria-prima para o processo de inversão é preparada a partir de açúcar granulado ou liquor de sacarose altamente refinado. As condições de inversão dependem da pureza e do grau de inversão do produto final. A produção de um açúcar invertido, sem cor, baixo conteúdo de cinzas e $50 \%$ invertido, é realizada partindo de uma solução altamente refinada aquecida a $60-70{ }^{\circ} \mathrm{C}$, acidificada com ácido clorídrico até atingir o $\mathrm{pH}$ 2,0 e mantido nestas condições por 2 horas. Para a produção de um açúcar com $95 \%$ de inversão a faixa de temperatura deve estar entre 70 a $80^{\circ} \mathrm{C}$ e mantido em meio ácido por um período de tempo maior que 2 horas. Em ambos os casos, os produtos são neutralizados com um álcali ou um sal com caráter alcalino até um $\mathrm{pH}$ estável de 3,8 a 4,8. Caso o grau de inversão desejado seja ultrapassado, adiciona-se açúcar granulado ou xarope de sacarose. $O$ produto final passa por carbono ativado para a retirada da cor sendo depois filtrado (Marignetti \& Mantovani, 1979/80).

A produção de açúcar invertido a partir de uma solução de sacarose de baixa pureza e alto conteúdo de cinzas requer mais ácido para manter o $\mathrm{pH}$ em 2,0 por causa do efeito tampão dos sais. Durante a inversão, temperaturas mais baixas são requeridas $\left(60^{\circ} \mathrm{C}\right)$ para evitar a formação excessiva de cor e durante armazenagem a cor do produto não permanece estável. Equipamentos de ferro devem ser evitados devido à natureza ácida da reação, podendo gerar corrosão, se o xarope contiver ferro acima de $0,001 \%$, o xarope irá gradualmente escurecer. Os materiais e equipamentos utilizados na linha de produção do açúcar invertido devem ser de aço inoxidável (Moroz et al., 1973).

Um processo descrito na literatura é realizado através da fervura de uma solução de sacarose por 30 minutos, a seguir a solução é resfriada a $70^{\circ} \mathrm{C}$, pois esta é a melhor temperatura para inversão ácida. $O$ ácido cítrico é adicionado e o liquor é mantido a temperatura constante, por 2 horas. Os produtos de degradação, em especial, o hidroximetilfurfural (HMF), são removidos pelo carbono ativado para evitar a formação da cor no produto. O xarope obtido contém 70 à $80 \%$ de açúcar invertido e menos que 2mg/100mL de 5-hidroximetilfurfural (Marignetti \& Mantovani, 1979/80). 
Um produto com melhor sabor é obtido, invertendo a sacarose com uma mistura de ácido cloridrico ou ácido sulfúrico e ácido fosfórico entre 70 e $90^{\circ} \mathrm{C}$. O xarope invertido é neutralizado com uma base adequada e misturado com ácido glutâmico (Marignetti \& Mantovani, 1979/80).

Açúcar invertido de alta qualidade é produzido com a adição de quantidades pré-determinadas de sacarose e água em um tanque, a mistura é fervida por 30 minutos até o liquor atingir a densidade adequada, sendo resfriado, em seguida, a $70^{\circ} \mathrm{C}$. $\mathrm{O}$ xarope é bombeado para um segundo tanque onde ocorre a adição de ácido cítrico, ficando neste tanque por 2 horas, aproximadamente. A mistura parte, então, para um terceiro tanque onde é resfriada a $10^{\circ} \mathrm{C}$, antes de ser armazenada. Durante o processo há perdas de aproximadamente $0,6 \%$ e o produto é bastante estável durante a armazenagem (Marignetti \& Mantovani, 1979/80).

Marignetti \& Mantovani, (1979/80) relatam a produção do açúcar invertido a partir do açúcar branco por aquecimento a $105^{\circ} \mathrm{C}$ e pH de 6,9 , durante 30 minutos. Esta solução é resfriada à $70^{\circ} \mathrm{C}$, adiciona-se ácido cítrico até $\mathrm{pH}$ de 2,4 e mantém nestas condições por 2 horas.

Outra técnica para a produção do açúcar invertido é através da inversão com resinas de troca iônica. A operação é contínua, o xarope de sacarose passa através de uma coluna vertical contendo os íons hidrogênio necessários para a inversão. $\mathrm{O}$ meio ácido promovido pela resina catiônica pode causar degradação do açúcar resultando em hidroximetilfurfural com a subseqüente formação de cor no xarope (Rodrigues et al., 2000). O grau de inversão depende do tempo de contato, temperatura, concentração do íon hidrogênio na resina, grau de reticulação e porosidade da resina (Moroz et al., 1973). Após a passagem pela resina ácida a inversão deve parar, portanto a próxima etapa do processo é a adição de álcali ou a passagem do xarope através de uma coluna aniônica contendo hidroxilas. A eficiência da inversão da sacarose reduz com a exaustão da resina, que pode ser regenerada com ácido sulfúrico ou clorídrico (Moroz et al., 1973; Bruder \& Moroz, 1981, Paschoalim, 1990).

Um método descrito na literatura consiste em inverter uma solução de sacarose de $60-80^{\circ}$ Brix, passando-a através de um trocador catiônico contendo um grupo ácidosulfồnico. O grau de inversão é controlado pela taxa de percolação através da resina de troca catiônica. A temperatura é mantida entre $15-20^{\circ} \mathrm{C}$, assim o xarope permanece incolor (Marignetti \& Mantovani, 1979/80). 
A Companhia de Açucares e Xaropes Concentrados produz açúcar invertido nas mais diversas concentrações com pouca alteração da cor e praticamente livre de minerais, em especial, ferro e cinzas. Estes xaropes, depois de armazenados e manipulados não apresentam aumento da cor. O processo se inicia pela clarificação do açúcar bruto, retirando a cor com carvão e carbono vegetal. O liquor passa através de colunas de trocas catiônicas para produzir o grau desejado de inversão. A temperatura do liquor tratado na resina catiônica deve estar entre 54,4 e $57,2^{\circ} \mathrm{C}$, embora possa ser superior à $71,1^{\circ} \mathrm{C}$. O pH do xarope desmineralizado é finalmente ajustado entre 4 e 6,5, para estabilizar a frutose no xarope (Marignetti \& Mantovani, 1979/80).

Marignetti \& Mantovani, (1979/80) reportam a desmineralização do xarope para produção de xarope liquido invertido, como uma operação adicional, através do tratamento do açúcar bruto com resinas catiônicas e aniônicas antes da fervura do liquor. $\mathrm{O}$ açúcar é clarificado com ácido fosfórico e óxido de cálcio em clarificadores, o efluente passa por uma etapa para a retirada da cor, então é filtrado e percolado através de colunas contendo trocadores catiônicos que diminuem o $\mathrm{pH}$ do liquor a um valor suficiente para inverter a sacarose. $\mathrm{O}$ liquor efluente é percolado por um leito aniônico que eleva o $\mathrm{pH}$ ao ponto de neutralidade. $\mathrm{O} \mathrm{pH}$ do liquor pode ser ajustado para o nível desejado regulando a vazão através da coluna de resina aniônica. A densidade adequada do produto é atingida levando o licor a um evaporador. $O$ concentrado deve ser resfriado antes de ser bombeado para a armazenagem.

Marignetti \& Mantovani, (1979/80) relatam a produção do açúcar líquido invertido, tratando o licor em uma coluna de troca catiônica forte e depois em uma resina de troca aniônica fraca. $\mathrm{O}$ grau de inversão pode ser controlado regulando a temperatura $e$ a vazão em que o liquor passa na primeira coluna. $O$ efluente da segunda coluna pode ainda passar por uma coluna de leito misto para um polimento final, dependendo da qualidade exigida para o produto.

Na FIG. 3 está representado o processo de produção do açúcar invertido a partir do açúcar de beterraba. Neste processo, o açúcar bruto é dissolvido usando água à $90^{\circ} \mathrm{C}$ para fazer uma solução de $60^{\circ} \mathrm{Brix}$. Após a primeira filtragem, retira-se a cor do melado em uma coluna com resina e resfria-se à $35-55^{\circ} \mathrm{C}$ em um trocador de calor de placas. $O$ licor é então tratado em 2 colunas catiônicas em série, seguida de uma coluna aniônica. O efluente é concentrado em um evaporador (Marignetti \& Mantovani, 1979/80). 


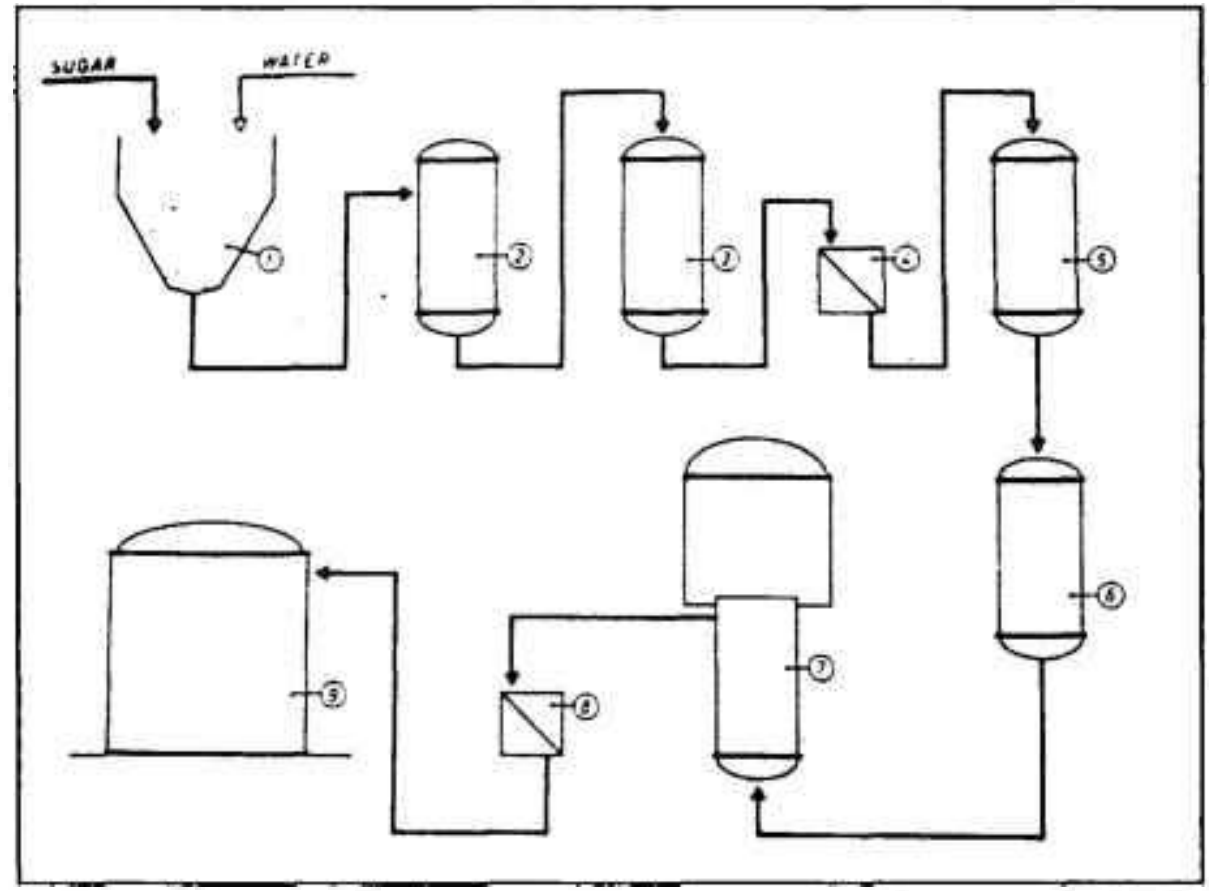

FIGURA 3 - Processo de produção do açúcar líquido invertido. 1: Misturador; 2: Filtros; 3: coluna com resinas para retirada da cor; 4 : trocador de calor; 5 : coluna com resina catiônica; 6 : coluna com resina aniônica; 7: evaporador; 8: resfriador; 9: armazenagem. Fonte: Marignetti \& Mantovani, 1979/80.

Nas instalações das empresas Millwall e Broadway o processo segue através das seguintes etapas: dissolução do açúcar, clarificação com ácido fosfórico, filtração, pasteurização, retirada da cor e desmineralização por resinas de troca iônica, concentração e armazenagem. Tanques de mistura são usados para o preparo de xaropes com diferentes proporções de açúcares (Marignetti \& Mantovani, 1979/80).

A mudança de cor durante o processo de inversão, em meio ácido ou com resina catiônica, pode ser reduzida mantendo o $\mathrm{pH}$ e a temperatura baixos. $O$ teor de cinzas do açúcar invertido é função da qualidade do açúcar e da água utilizados (Marignetti \& Mantovani, 1979/80).

A produção do açúcar líquido invertido pode ser realizada ainda através de um terceiro processo, a hidrólise enzimática. Este processo é utilizado quando se deseja produzir pequenas quantidades de xarope e um produto com características especiais de aroma e cor, os quais poderiam ser prejudicados pela hidrólise ácida (Moroz et al., 1973; Paschoalim, 1990).

O processo de inversão enzimático apresenta vantagens em relação ao método ácido. Na inversão enzimática não ocorre alteração na cor do produto ou no flavor do xarope de cana, é menos corrosivo aos equipamentos da planta e por ser um método mais brando não decompõe os carboidratos e não há a formação de compostos indesejáveis, 
como o furfural. O produto apresenta baixo teor de cinzas, pois não ocorre a utilização de ácido para a inversão, nem de base para a neutralização. (Moroz et al., 1973; Marignetti \& Mantovani, 1979/80; Groves, 1998; Rodrigues et al., 2000).

A enzima utilizada no processo é a invertase de levedura (EC 3.2.1.26). Esta enzima é utilizada na inversão dos xaropes de sacarose, o que deu origem ao nome da enzima, e na obtenção de centros macios em chocolates e balas. A maioria das leveduras contém dois tipos de invertase: a fructosidase e a glicosidase, porém a que predomina é a primeira, pois promove a remoção da frutose da molécula de sacarose.

Os centros macios demoram em média três semanas para se formarem a uma temperatura de $18^{\circ} \mathrm{C}$. Parte da sacarose do recheio sofre a ação da enzima, decompondo-se em monossacarídeos que não cristalizam facilmente, mesmo em altas concentrações, assim o recheio não se solidifica (Moroz et al., 1973; Paschoalim, 1990; Groves, 1998).

Para obter um xarope invertido, pelo método enzimático, parte-se de uma solução contendo entre 50 à $68 \%$ de sacarose. A temperatura de operação varia entre 60$70^{\circ} \mathrm{C}$ e o pH entre 4,5 e 5,5. A concentração de enzima é de 0,005 à $0,02 \%$ do substrato sólido. A taxa de inversão aumenta com o aumento de temperatura, sendo o limite de $70^{\circ} \mathrm{C}$, acima desta temperatura a enzima perde a atividade (Moroz et al., 1973).

$\mathrm{Na}$ literatura, encontra-se descrito um processo contínuo de fabricação do açúcar invertido pela enzima invertase. $O$ grau de inversão é diretamente proporcional ao tempo de contato enzima-substrato. A percolação de uma solução de açúcar à $65^{\circ} \mathrm{C}$ e pH 5 através de uma cisterna preenchida com carvão ativado contendo invertase adsorvida resultará em um produto com $60 \%$ de inversão. O carvão retira a cor do produto (Marignetti \& Mantovani, 1979/80).

\subsection{Contaminação microbiana do açúcar líquido}

A armazenagem do açúcar líquido é feita em tanques associados á bombas, tubulações e medidores de vazão. Em geral, o sistema é constituído por três tanques: um tanque de recebimento, um tanque para ajuste da proporção de açúcares e um tanque para transporte. A armazenagem constitui uma etapa importante do processamento, pois em geral é a etapa mais crítica para crescimento de microrganismos (Bruder \& Moroz, 1981).

Os tanques, em geral, são cilíndricos fabricados com aço-inoxidável, internamente cobertos com uma pintura a base de epóxi (Bruder \& Moroz, 1981). As tubulações, válvulas e acessórios associados ao tanque também devem ser construídos com 
o mesmo material. As tubulações devem ser projetadas para permitir a fácil sanitização e manutenções periódicas evitam o crescimento de microrganismos. A limpeza pode ser realizada com água morna contendo $200 \mathrm{ppm}$ de cloro. A presença de fungos na superfície dos equipamentos pode ser eliminada com limpeza mecânica e lavagem com água quente contendo cloro. Todos os tanques devem ser testados diariamente para contagem microbiana (Bruder \& Moroz, 1981).

A principal fonte de contaminação por microorganismos é o ar que fica sobre o açúcar líquido no tanque de armazenagem. Deve ser evitado que o vapor de água presente no ar fique saturado, uma vez que a sua condensação dilui a camada superior do açúcar, criando um meio ideal para o crescimento de bactérias e leveduras, portanto é fundamental que ar estéril circule no interior do tanque de armazenagem, isso pode ser alcançado passando ar filtrado sobre o açúcar líquido (Marignetti \& Mantovani, 1979/80; Bruder \& Moroz, 1981).

Outros métodos de armazenagem de xarope incluem o uso de uma tampa flutuante que cobre toda a superfície do xarope armazenado. Outra forma de evitar o contato com o ar é usar uma substância acima da superfície do açúcar, como óleo mineral ou um gás não-oxidante, como o $\mathrm{CO}_{2}$, que é injetado, aproximadamente $5 \mathrm{~cm}$ abaixo da superficie do xarope (Marignetti \& Mantovani, 1979/80).

$\mathrm{O}$ baixo conteúdo de cinzas e o alto teor de sólidos solúveis permitem o armazenamento prolongado do açúcar líquido. Uma solução contendo $72,7 \%$ de açúcares evita o crescimento de microrganismos, porque nessa concentração mesmo os microrganismos osmotolerantes não conseguem sobreviver. $\mathrm{O}$ tempo de armazenamento pode aumentar adicionando glicose ou ácido cítrico à solução. Em temperaturas variando entre -5 e $15^{\circ} \mathrm{C}$ o açúcar líquido pode ficar armazenado durante 4 meses sem modificação de suas propriedades e a armazenagem do açúcar em temperaturas entre 15 e $35{ }^{\circ} \mathrm{C}$ evita-se o escurecimento do açúcar (Marignetti \& Mantovani, 1979/80).

A técnica de sanitização do açúcar relatada na literatura é a radiação ultravioleta. Soluções de sacarose contaminadas circularam continuamente pelo esterilizador a uma vazão de $75 \mathrm{~L} / \mathrm{min}$, através de duas unidades de ultravioleta em série, resultando uma queda da contagem microbiana aceitável. Essa técnica também foi aplicada em uma solução de glicose, as unidades de ultravioleta dispostas em paralelo, cada uma trabalhando com uma vazão de $37,5 \mathrm{~L} / \mathrm{min}$, resultou em esterilização inadequada, decorrente provavelmente da baixa turbulência (Marignetti \& Mantovani, 1979/80). 
A radiação ultravioleta também pode ser aplicada no produto final, já armazenado. $\mathrm{O}$ açúcar circula por um esterilizador com ultravioleta situado fora do tanque, em tubos. Este tratamento não é adequado para produtos coloridos e o uso da lâmpada de ultravioleta pode gerar o sabor de ozônio. A exposição do açúcar á radiação ultravioleta reduz o pH e a intensidade da cor logo após a irradiação. Quanto maior o período de exposição a radiação maior o desenvolvimento de cor durante a armazenagem. $\mathrm{O}$ xarope que recebeu radiação ultravioleta e com pH menor que 3 apresenta mudança de cor maior que o xarope que não foi irradiado. Com pH menor que 6 ocorre o inverso, portanto o melhor $\mathrm{pH}$ para armazenar o xarope que sofreu tratamento com ultravioleta deve estar entre 4 e 6 . Durante a irradiação ocorre a formação de dióxido de carbono proveniente da decomposição da frutose, quanto maior o tempo de tratamento maior a formação de dióxido de carbono (Marignetti \& Mantovani, 1979/80). A FIG. 4 apresenta um tanque de armazenagem de açúcar líquido em que a esterilização por ultravioleta ocorre no ar que alimenta o tanque.

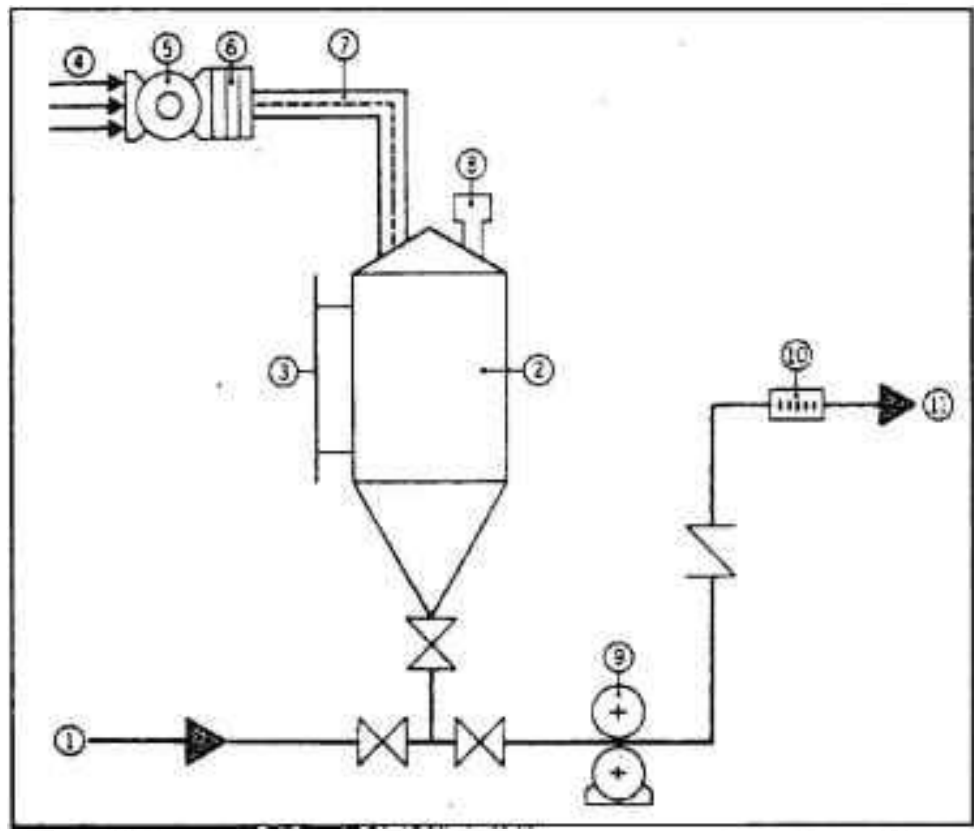

FIGURA 4 - Esquema de um silo de armazenagem de açúcar líquido. 1: entrada do açúcar líquido; 2: tanque de armazenagem; 3: medidor de nível; 4: entrada de ar; 5: ventilador; 6 micro filtros; 7: lâmpadas de UV; 8: vent; 9: bombas; 10: medidor de vazão; 11 saída do açúcar líquido.

\subsection{Propriedades físico-químicas do açúcar líquido}

A literatura é escassa em trabalhos que relatem as propriedades físico-químicas do açúcar invertido, os poucos estudos existentes são obtidos por uma comparação com o xarope de sacarose e são das décadas de 40 e 50. 
O xarope invertido com maior valor comercial é aquele em que $55 \%$ da sacarose foi convertida em glicose e frutose possibilitando trabalhar com $76,5 \%$ de sólidos solúveis, sem riscos de cristalização (Paschoalim, 1990; Rodrigues et al., 2000). O objetivo dos refinadores é obter o máximo de sólidos solúveis no açúcar líquido para reduzir os custos de transporte e a quantidade de água a ser evaporada durante o processamento (Davis \& Prince, 1955).

A solubilidade da sacarose a $20^{\circ} \mathrm{C}$ é $67,1 \%$. Este valor estabelece a máxima concentração permitida para evitar a cristalização durante a armazenagem e o transporte. A adição dos monossacarídeos, glicose e frutose, à solução de sacarose permitem o aumento do teor de sólidos solúveis sem aumentar o risco de cristalização. Os açúcares líquido, contendo glicose e frutose, podem ser produzidos com alto conteúdo de sólidos devido a alta solubilidade da frutose. A glicose apesar de ser o menos solúvel dos açúcares quando comparado com a sacarose e a frutose, pode permanecer em solução por longos períodos de tempo, mesmo em condições de saturação, como pode ser observado na FIG. 5 (Junk et al., 1947; Davis \& Prince, 1955)

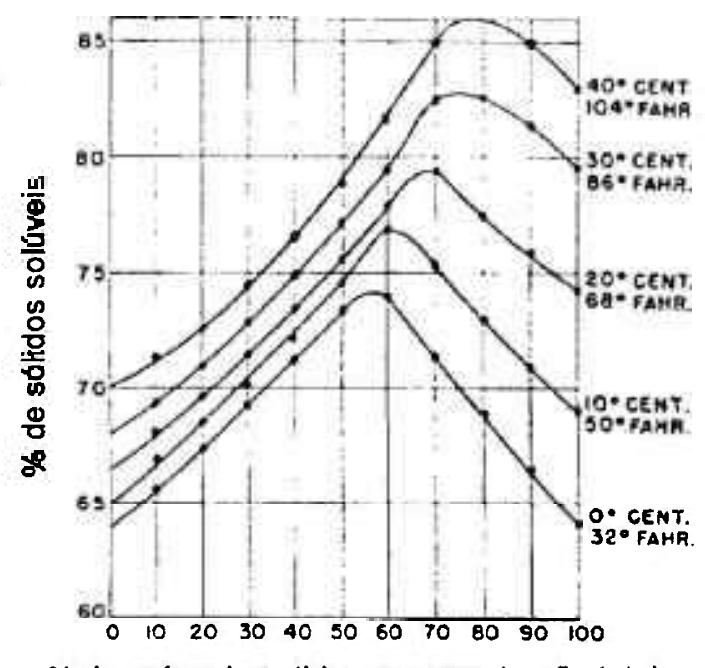

$\%$ de açúcar invertido na concentração total

FIGURA 5 - Porcentagem de sólidos solúveis permitida em uma solução contendo sacarose e diferentes concentraçōes de açúcar invertido. Fonte: Junk et al., 1947.

A densidade da solução de sacarose aumenta com o aumento da concentração de açúcar invertido. A TAB. 1 lista a composição das soluções de açúcar invertido que permitem a máxima solubilidade em várias temperaturas. $O$ aumento da temperatura proporciona aumento na concentração de açúcares em solução (Moroz et al., 1973). 
TABELA 1 - Composição da solução de sacarose e açúcar invertido que permite máxima solubilidade cm difierentes temperaturat

\begin{tabular}{c|c|c|c}
\hline Temperatura $\left({ }^{\circ} \mathrm{C}\right)$ & \% sacarose & \% açúcar invertido & \% de água \\
\hline 0 & 43,7 & 27,2 & 29,1 \\
\hline 10 & 40,9 & 31,8 & 27,3 \\
\hline 15 & 39,1 & 34,8 & 26,1 \\
\hline 23,15 & 36,3 & 39,9 & 23,8 \\
\hline 30 & 33,6 & 45,4 & 21,0 \\
\hline 40 & 31,1 & 50,7 & 18,2 \\
\hline 50 & 27,7 & 58,0 & 14,3 \\
\hline
\end{tabular}

Fonte: Moroz et al., 1973.

A viscosidade das soluções de açúcares é uma propriedade importante para a indústria, pois está diretamente relacionada à fluidez do xarope, determinando as condições de estocagem, o projeto de equipamentos, de bombas e das tubulações. A TAB. 2 mostra a viscosidade das soluções com diferentes concentrações de açúcar à $20^{\circ} \mathrm{C}$ (Moroz et al., 1973; Paschoalim, 1990). O xarope contendo açúcar invertido contém maior teor de sólidos se comparado com o xarope contendo apenas sacarose, portanto sua viscosidade é maior. Porém, se compararmos os dois xaropes com a mesma concentração de sólidos, o xarope de sacarose terá maior viscosidade já que é constituído por moléculas maiores que a glicose e a frutose. A TAB. 3 mostra o efeito que os monossacarídeos têm sobre a viscosidade de um xarope (Davis \& Prince, 1955; Moroz et al., 1973).

TABELA 2 - Viscosidade do acúcar líquido invertido em diferentes concentraçōes.

\begin{tabular}{c|c} 
TABELA 2 - Viscosidade do acúcar líquido invertido em diferentes concentraçoes. \\
\hline \% em massa de açúcar invertido & Viscosidade (N.s $\left./ \mathrm{m}^{2}\right)$ \\
\hline 73,7 & 1,972 \\
\hline 73,0 & 1,433 \\
\hline 71,7 & 0,943 \\
\hline 70,7 & 0,719 \\
\hline 67,6 & 0,313 \\
\hline 64,3 & 0,143 \\
\hline
\end{tabular}

Fonte: Moroz et al., 1973. 
TABELA 3 - Efeito do açúcar invertido na viscosidade do açúcar líquido.

\begin{tabular}{c|c|c}
\hline \multicolumn{2}{c|}{$\%$ de açúcares (base seca) } & $\begin{array}{c}\text { Viscosidade (cP) à } 22^{\circ} \mathrm{C} \text { e } \\
65 \% \text { de sólidos }\end{array}$ \\
\hline \hline Invertido & Sacarose & 133 \\
\hline 0 & 100 & 127 \\
\hline 10 & 90 & 97 \\
\hline 50 & 50 & \\
\hline
\end{tabular}

Fonte: Davis \& Prince, 1955.

O açúcar líquido invertido é mais eficaz na redução do ponto de congelamento quando comparado à solução de sacarose. A TAB. 4 mostra que o aumento da concentração de açúcar invertido em solução reduz o ponto de congelamento (Davis \& Prince, 1955; Moroz et al., 1973).

TABELA 4 - Ponto de congelamento do açúcar invertido.

\begin{tabular}{c|c|c}
\hline Temperatura $\left({ }^{\circ} \mathrm{C}\right)$ & $\%$ em massa da sacarose & $\begin{array}{c}\% \text { em peso do açúcar } \\
\text { invertido }\end{array}$ \\
\hline \hline-6 & 46 & 35 \\
\hline-10 & 55 & 44 \\
\hline-15 & 65 & 54 \\
\hline
\end{tabular}

Fonte: Moroz et al., 1973.

O açúcar invertido devido à presença da frutose é extremamente higroscópico, com capacidade de absorver água mesmo em umidades relativas menores que $60 \%$. Essa característica permite o seu uso em uma variedade de produtos alimentícios assim como produtos não alimentícios, uma vez que a quantidade de açúcar invertido pode ser dosada para regular a umidade do alimento (Davis \& Prince, 1955; Moroz et al.; 1973).

A cor do açúcar serve com índice de qualidade do produto e está diretamente relacionada ao alimento que será utilizado; em geral, a cor muito forte é uma característica indesejada no produto. A cor do xarope invertido é influenciada pela temperatura e tempo aplicados durante a inversão e o pH da solução. O aquecimento por um tempo prolongado, durante o processo de inversão, proporciona o aumento da cor. Em relação ao $\mathrm{pH}$, pode-se observar na FIG. 6 que o pH na faixa neutra favorece a formação da cor, portanto é importante manter o $\mathrm{pH}$ da solução na faixa ácida, como observado no item anterior (Davis \& Prince, 1955) 


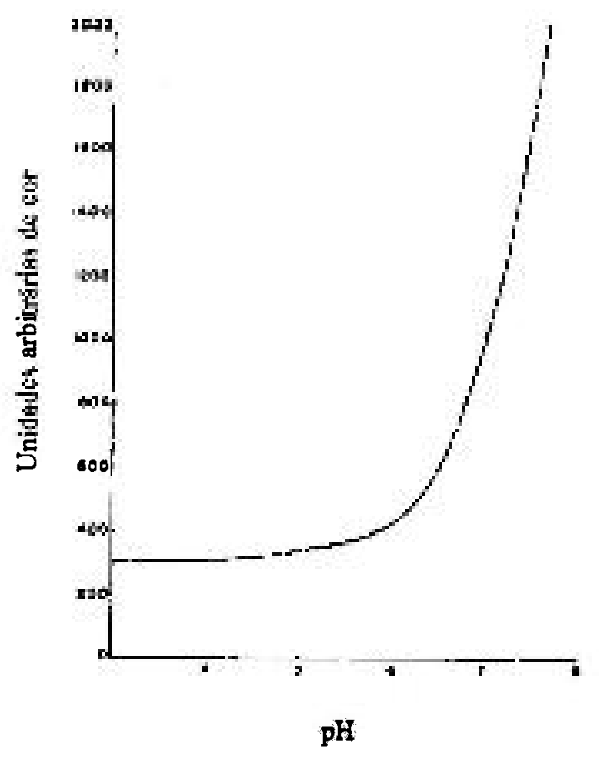

FIGURA 6: Desenvolvimento da cor em função do $\mathrm{pH}$ em um xarope contendo $93 \%$ de açúcar invertido. Fonte: Junk et al., 1947.

A doçura é uma sensação de sabor que depende da concentração e mistura de carboidratos, $\mathrm{pH}$, temperatura e outros componentes que podem afetar a fisiologia do paladar e na maioria das vezes esta determinação é subjetiva (Davis \& Prince, 1955; Paschoalim, 1990). As soluções contendo até $10 \%$ de sacarose são mais doces que o açúcar invertido, enquanto que acima de $10 \%$ o xarope invertido é mais doce (Moroz et al., 1973). Segundo Davis \& Prince, 1955 há um consenso parecendo indicar que não há diferenças significativas entre o xarope de sacarose e o xarope invertido quanto ao poder adoçante, embora o açúcar contendo monossacarídeos tenha um sabor parecido a mel. A doçura relativa de vários componentes está apresentada na TAB. 5 .

TABELA 5 - Docura relativa de diversos açúcares.

\begin{tabular}{c|c}
\hline Açúcares & Doçura relativa \\
\hline Frutose & $1,1 \mathrm{a} 1,8$ \\
\hline Sacarose & 1,0 \\
\hline Açúcar invertido & 0,9 \\
\hline Glicose & 0,7
\end{tabular}

Fonte: adaptado de Paschoalim, 1990.

O teor de cinzas, assim como a cor, também é utilizado como índice de qualidade sendo um guia útil, pois pode ser medido rapidamente por métodos 
condutimétricos. $\mathrm{O}$ açúcar invertido pelo próprio processo de produção em que ocorre a adição de ácido e depois base para parar a inversão contribui para o aumento das cinzas do produto (Davis \& Prince, 1955).

\subsection{Aplicação do açúcar líquido invertido}

As características que tornam o açúcar invertido um ingrediente único são: higroscopicidade, solubilidade, resistência à cristalização, viscosidade, doçura, atividade redutora e estabilidade. Este açúcar é mais estável que o xarope de sacarose, uma vez que a sacarose pode sofrer hidrólise após a sua adição em bebidas ou outros alimentos com caráter ácido (Moroz et al., 1973).

Em termos de custo de transporte e armazenagem o açúcar invertido é mais vantajoso que o xarope de sacarose. Para o transporte de um mesmo volume destes dois produtos, o invertido proporciona maior quantidade de açúcares, uma vez que o invertido contém apenas $23,5 \%$ de água, enquanto o xarope de sacarose contém $32,5 \%$, além do menor teor de água para a evaporação durante o processo. A maior concentração de sólidos dissolvidos permite que o açúcar líquido tenha tempo de vida de prateleira maior quando comparado com outros açúcares líquidos (Davis \& Prince, 1955; Moroz et al., 1973).

As indústrias de bebidas são os grandes consumidores do açúcar invertido. Alguns fabricantes adotam o açúcar líquido contendo somente sacarose, mas a maioria prefere o açúcar invertido, principalmente pela diferença no flavor. A dúvida na escolha entre um açúcar e outro pode surgir devido à natureza ácida dos refrigerantes, que durante o processo de engarrafamento podem provocar a quebra da molécula de sacarose, aumentando o conteúdo de açúcar da bebida. Portanto, muitos fabricantes acabam escolhendo a sacarose porque acreditam estar ganhando a inversão no próprio produto (Davis \& Prince, 1955; Moroz et al., 1973; Marignetti \& Mantovani, 1979/80).

Em produtos assados, como bolos, a umidade e o frescor de um produto feito em casa é o objetivo do fabricante. A adição de pequenas quantidades de açúcar invertido à massa melhora a cremosidade dos açúcares e gorduras, assim como a rápida e uniforme distribuição dos ingredientes. $O$ açúcar invertido retém a umidade durante o processo de cozedura e resfriamento, produzindo um produto com textura úmida e aveludada. A menor concentração de sacarose presente, reduz o número de partículas cristalizadas que podem romper a estrutura celular dos bolos e diminuir a vida de prateleira. A concentração de 
açúcar invertido deve ser limitada devido ao seu efeito no aumento da cor (Moroz et al., 1973; Marignetti \& Mantovani, 1979/80).

$\mathrm{Na}$ indústria de panificação pode-se usar tanto o xarope invertido como o de sacarose, uma vez que a sacarose é invertida durante o processo de fermentação, porém o invertido muitas vezes é escolhido devido a sua habilidade em absorver a umidade (Davis \& Prince, 1955; Marignetti \& Mantovani, 1979/80; Groves, 1998).

$\mathrm{O}$ açúcar invertido é bastante efetivo na produção de cookies. Ele influencia positivamente no tempo de prateleira, na cor e na diminuição das quebras do produto. 0 açúcar invertido reduz a cristalização da sacarose, uma vez que parte dos açúcares é constituido por glicose e frutose. Durante o resfriamento do cookie, quantidades menores de sacarose recristalizam e os cristais formados são menores assim os pontos de fratura relacionados a quebra do cookie têm menor tendência a se formarem (Moroz et al., 1973).

O açúcar invertido permite ao cookie obter a cor característica sem assar demais o produto, evitando a perda da umidade. A fração de frutose inicia a caramelização a uma temperatura baixa, de $60^{\circ} \mathrm{C}$. Mesmo em cookies com baixo conteúdo de açúcar, recomenda-se a adição de 2 a $5 \%$ de açúcar invertido para obter uma cor dourada na borda do cookie (Moroz et al., 1973).

Em produtos confeitados a aplicação do açúcar invertido é vasta. Em balas duras, fondants e centros cremosos usa-se entre 0-10\% de açúcar invertido. Em doce de leite, caramelo, nougat, marshmallow e geléias a base de ágar usa-se entre $15-25 \%$ de açúcar invertido (Moroz et al., 1973).

O sucesso da indústria de balas está diretamente relacionada à habilidade em reduzir a taxa de cristalização, esse processo pode ser alcançado através de produtos químicos, como creme de tártaro ou ácido acético, que hidrolisam a sacarose formando açúcar invertido, ou na adição direta de açúcar invertido (Davis \& Prince, 1955; Moroz et al., 1973).

A indústria de laticínios evita o uso do xarope invertido por duas razões. A primeira delas é a reação de escurecimento que ocorre entre as proteínas e os açúcares redutores e no caso de sobremesas congeladas a redução brusca no ponto de congelamento (Davis \& Prince, 1955; Moroz et al., 1973).

Nos produtos enlatados a escolha do açúcar depende de fatores com o $\mathrm{pH}$ e cor. $\mathrm{O}$ açúcar invertido sofre mudança de cor em certos pHs. A maior estabilidade da cor ocorre em pH menor que 4,2. Em pHs acima de 6,5 o açúcar invertido tem a tendência a escurecer ainda mais sob aquecimento. Portanto, a sacarose é usada nas embalagens de ervilhas e 
milho que são embaladas em $\mathrm{pH}$ neutro, enquanto o xarope invertido é usado em frutas enlatadas (Davis \& Prince, 1955; Moroz et al., 1973).

Em produtos de confeitaria são usados a sacarose e o açúcar invertido, apesar da sacarose ter preferência decorrente de sua cristalização que é responsável pela estrutura dos confeitos. Excesso de açúcar invertido é evitado pela sua tendência em absorver água o que pode tornar o confeito grudento. Alguns confeitos, porém, devem conter açúcar invertido, permitindo a fluidez, além de ser essencial sua adoção em certos doces para evitar a fermentação (Davis \& Prince, 1955; Moroz et al., 1973).

\subsection{Processamento de alimentos por irradiação}

A irradiação de alimentos é um processo que expõe o produto a energia ionizante como raios gama emitidos pelos radioisótopos ${ }^{60} \mathrm{Co} \mathrm{e}{ }^{137} \mathrm{Cs}$ ou a elétrons de alta energia e raios X. A exposição à radiação é realizada em taxas controladas por um tempo determinado e com o objetivo previamente definido (Farkas, 2006). A quantidade de energia proveniente da radiação ionizante por unidade de massa é denominada de dose de radiação ou simplesmente dose, sendo medido em grays ou rad. A dose empregada é um equilibrio entre o que é necessário e o que pode ser tolerado no produto sem ocorrer mudanças indesejáveis como off-flavour e alterações na textura. Em termos de energia Gy equivale a 1 Joule de energia absorvida por quilo de alimento (World Health Organization, 1977). A dose de $10 \mathrm{kGy}$ (ou $1 \mathrm{Mrad}$ ) irá aumentar a temperatura de 1 grama de água em apenas $2,68^{\circ} \mathrm{C}$ por esta razão esta técnica também recebe o nome de processo frio (Lagunas-Solar \& Matthews, 1985; Farkas, 2006).

A radiação ionizante é formada por partículas (elétrons de alta energia) ou ondas eletromagnéticas (raios gama) capazes de remover os elétrons dos átomos produzindo átomos ou moléculas com cargas, ou seja, ions. Também pode produzir moléculas e átomos excitados, por esta razão a radiação ionizante é capaz de iniciar ou induzir mudanças químicas. Estas alterações reduzem ou eliminam eficientemente a população de microrganismos patogênicos e deteriorantes, reduz a perda de alimentos, aumenta a vida de prateleira, inibi o brotamento, desinfesta alimentos frescos de insetos, retarda a maturação de algumas frutas e legumes ao produzir reações bioquímicas nos processos fisiológicos dos tecidos vegetais e minimiza ou mesmo evita a adição de produtos químicos, enquanto mantém as qualidades nutricionais e sensoriais (Lagunas- 
Solar \& Matthews, 1985; Loaharanu, 1992; Del Mastro, 1999). A TAB. 6 mostra alguns efeitos de três faixas de doses de irradiação em alimentos.

O primeiro uso comercial da irradiação de alimentos ocorreu em condimentos na Alemanha em 1957, usando acelerador de elétrons (Diehl, 2002).

Em um irradiador industrial é impossível conseguir uma distribuição de doses uniforme. Assim, para cada alimento a ser irradiado é definido uma dose média, máxima ou mínima apropriada, desta maneira as partes do alimento não devem receber menos que a dose mínima necessária e mais que a dose máxima estipulada. A fixação de doses minimas é de extrema importância quando se deseja eliminar organismos patogênicos (World Health Organization, 1977; Crawford \& Ruff, 1996).

A determinação do intervalo de doses e do tipo de irradiação (raios gama, feixe de elétrons ou raios $\mathrm{X}$ ) é importante, junto com o estabelecimento do momento mais adequado para a irradiação de determinado produto (durante as diversas fases de processamento), se o alimento deve ser embalado e qual o tipo de material deverá ser a embalagem e a temperatura antes, durante a após a irradiação (World Health Organization, 1981).

A embalagem utilizada para a irradiação não deve interagir com o produto embalado. O FDA aprova para doses até $10 \mathrm{kGy}$, o papel e o papelão e para $60 \mathrm{kGy}$ o material polimérico (Villavicencio, 1998)

Somente os alimentos processados com boas condições de fabricação devem ser irradiados (World Health Organization, 1981; Byrne, 1996). Os oponentes à irradiação de alimentos alegam que a irradiação pode encobrir alimentos deteriorados, porém os microrganismos que causam deterioração produzem descolorarão e odores desagradáveis que não podem ser mascarados pela irradiação (Crawford \& Ruff, 1996).

A irradiação repetida de um alimento deve ser evitada, pois pode ocorrer uma degradação do alimento sob o ponto de vista organoléptico e sensorial (World Health Organization, 1977).

Os métodos comumente utilizados para a preservação de alimentos, como aquecimento, resfriamento, congelamento, desidratação, concentração, adição de produtos químicos, fermentação, embalagem a vácuo, entre outros, podem continuar a serem utilizados em larga escala, porém a preocupação da população com produtos químicos adicionados aos alimentos e a utilização de fumigantes podem contribuir para o aumento no interesse pela radiação ionizante para a preservação de alimentos ou mesmo a utilização 
combinada da irradiação com estas tecnologias tradicionais podem aumentar a eficácia e reduzir os custos de processos (Moy, 1989).

As principais vantagens do processo de irradiação de alimentos são o pequeno aumento de temperatura induzido pelo tratamento, a ausência de residuos, a possibilidade de tratar o produto em sua embalagem final e a economia de energia frente a processos tradicionais. $\mathrm{O}$ congelamento de $0,45 \mathrm{~kg}$ de um alimento gasta $2 \mathrm{kWh}$ de energia e para enlatar essa mesma quantidade o gasto é de $3 \mathrm{kWh}$, para a radiação ionizante gasta-se apenas 0,5 kWh (Lagunas-Solar \& Matthews, 1985). Entre as desvantagens estão os altos custos de implementação e a baixa aceitação pelos consumidores (Ehlermann, 1990). A baixa aceitação pelos consumidores de produtos irradiados se deve a orientação deficiente, muitos associam a irradiação de alimentos com armas nucleares e radioatividade ou a perda nutricional do alimento. Estudos comprovam que a educação dos consumidores sobre os benefícios e a segurança dos alimentos irradiados aumenta significativamente o interesse e a aceitação por estes produtos. A informação correta sobre a irradiação de alimentos permite que o consumidor formule suas próprias conclusões baseadas em fatos concretos (Crawford \& Ruff, 1996; Delincée, 1998; Diehl, 2002; Oliveira \& Sabato, 2004).

As controvérsias levantadas pelo uso da irradiação de alimentos são semelhantes às apresentadas há 100 anos para a pasteurização do leite (Henon, 1995; Crawford \& Ruff, 1996). A opinião pública sobre a irradiação de alimentos, nas décadas de 50 e 60, em geral era positiva, com o avanço do movimento anti-nuclear a partir de 1970 a oposição a irradiação de alimentos cresceu, tendo que superar barreiras criadas pelo preconceito, falta de informação e medidas legais restritivas (Diehl, 2002).

A irradiação não torna o produto radioativo e em baixas doses não causa alteração acentuada na qualidade dos alimentos e em seus macronutrientes como proteínas, carboidratos e gorduras. As perdas de aminoácidos, ácidos graxos essenciais e minerais são pequenas. A qualidade nutricional de alimentos preservados pela irradiação pode ser igual, ou melhor, que os alimentos preservados por métodos térmicos. A irradiação em altas doses, como por exemplo, para a esterilização, gera a perda de vitaminas, contudo as perdas de riboflavina, niacina e tiamina não são maiores que as apresentadas em um processo térmico (Raica \& Scott, 1972; Crawford \& Ruff, 1996).

As alterações nas propriedades sensoriais dos alimentos são resultantes principalmente de reações químicas nos macronutrientes, lipídeos, os aminoácidos e os carboidratos, que podem ocorrer em doses maiores que $10 \mathrm{kGy}$. Os lipídeos podem ser oxidados gerando o sabor rançoso, este processo pode ser evitado pela eliminação do 
oxigênio ou pelo processamento em atmosfera de nitrogênio. Os aminoácidos podem apresentar quebra nas cadeias com a eliminação de compostos sulfurosos, porém estas reações ocorrem em pequena escala não acarretando perdas ao valor nutricional. $\mathrm{E}$, finalmente os carboidratos podem ser quebrados, como, no caso da pectina, por exemplo, resultando em amaciamento de frutas e vegetais ou como no caso da redução do tempo de cocção dos feijões (Villavicencio, 1998).

A formação dos radicais livres nos alimentos irradiados sempre foi uma questão preocupante, uma vez que acreditava-se que esses radicais poderiam ter um efeito tóxico no organismo humano. Estudos realizados com animais alimentados com leite em pó, irradiado com $45 \mathrm{kGy}$, não mostrou efeito mutagênico e nem a formação de tumores nos animais em nove gerações sucessivas Estes produtos radiolíticos são produzidos também em outros tratamentos como na torrefação de pães, resfriamento e congelamento, além de estar presente em quantidades variadas em vegetais, frutas, carnes e peixes e reagem entre si na presença de líquidos como a saliva da boca. A irradiação em baixas doses gera menos produtos radiolíticos que os formados em um bife de churrasco. O Food and Drug Administration (FDA) estimou que alimentos irradiados com doses de $1 \mathrm{kGy}$ formaram $3 \mathrm{mg}$ de radicais livres/kg de alimentos (Moy, 1986; Crawford \& Ruff, 1996). Muitos dos produtos radiolíticos encontrados nos alimentos irradiados são encontrados também no tratamento térmico convencional, fotólise, catálise de íons metálicos, catálise enzimática, ultra-som, moagem ou durante a estocagem e a interação de oxigênio e peróxidos (Villavicencio, 1998).

A inativação microbiana gerada pela radiação ionizante é decorrente principalmente da alteração de ácidos nucléicos e pelos efeitos oxidativos dos radicais originários da radiólise da água. A irradiação pode inativar parasitas protozoários ou helmintos e reduzir significativamente o crescimento de bactérias em peixe, aves, frutos do mar e carne vermelha. As diferenças na sensibilidade dos microrganismos frente a radiação estão relacionadas a diferenças em sua estrutura química e física e na sua capacidade em se recuperar dos danos causados pela irradiação. Por esta razão, a quantidade de energia requerida para controlar os microorganismos nos alimentos varia de acordo com a resistência da espécie e com o número de microrganismos presentes. Além disso, outros fatores como composição do meio, teor de umidade, temperatura durante a irradiação, presença ou ausência de oxigênio, se o produto está fresco ou congelado influenciam na resistência a radiação, particularmente no caso de células vegetativas (Del Mastro, 1999; Farkas, 2006). 
A possibilidade que a irradiação possa alterar as propriedades dos microrganismos patogênicos de forma a impedir sua correta identificação é uma preocupação, porém estudos mostram que a vasta maioria das características dos microrganismos permanece inalterada (Crawford \& Ruff, 1996).

O Comitê formado pela Organização das Nações Unidas para a Agricultura e Alimentação (FAO), Agência Internacional de Energia Atômica (IAEA) e Organização Mundial de Saúde (WHO) concluiu em 1980 que a irradiação de qualquer alimento com dose superior a $10 \mathrm{kGy}$ não apresenta perigo toxicológico e nenhum problema nutricional e microbiológico (World Health Organization, 1981). Em 1997, este mesmo comitê examinou a segurança dos alimentos irradiados com doses maiores que $10 \mathrm{kGy}$, apesar de poucos alimentos tolerarem doses dessa mesma magnitude, sem perder a qualidade sensorial. Animais alimentados com alimentos irradiados com doses de $70 \mathrm{kGy}$ não apresentaram nenhum efeito adverso. Este grupo de estudo mostrou que alimentos irradiados em doses apropriadas para obter o objetivo tecnológico pretendido é seguro e nutricionalmente adequado (Aziz \& Moussa, 2002; Diehl, 2002).

Os pesquisadores destacam a necessidade de se adotar uma mesma legislação mundial para facilitar o comércio internacional de alimentos irradiados e ajudar no desenvolvimento do mercado para estes produtos, já que a falta de harmonia na legislação constitui uma barreira para o comércio internacional (Hackwood, 1991; Thakur \& Singh, 1995; Camargo, 2004).

No Brasil, existem dezenas de pequenos sistemas de irradiação gama, a maioria deles localizada em hospitais e hemocentros e utilizados na irradiação de sangue, e alguns irradiadores de grande porte com diversas finalidades, como o beneficiamento de pedras preciosas, a esterilização de materiais cirúrgicos e, em menor parte, a irradiação de alimentos. A maioria está localizada no Estado de São Paulo, como, por exemplo, a EMBRARAD em Cotia que se dedica a prestar serviços de irradiação de diversos produtos para terceiros e da Johnson \& Johnson licenciado para esterilizar a sua própria produção de seringas, cateteres, suturas, fraldas descartáveis e outros produtos médicos (Del Mastro, 1999; Leal et al., 2004). 
TABELA 6 - Relação de doses e seus efeitos nos alimentos.

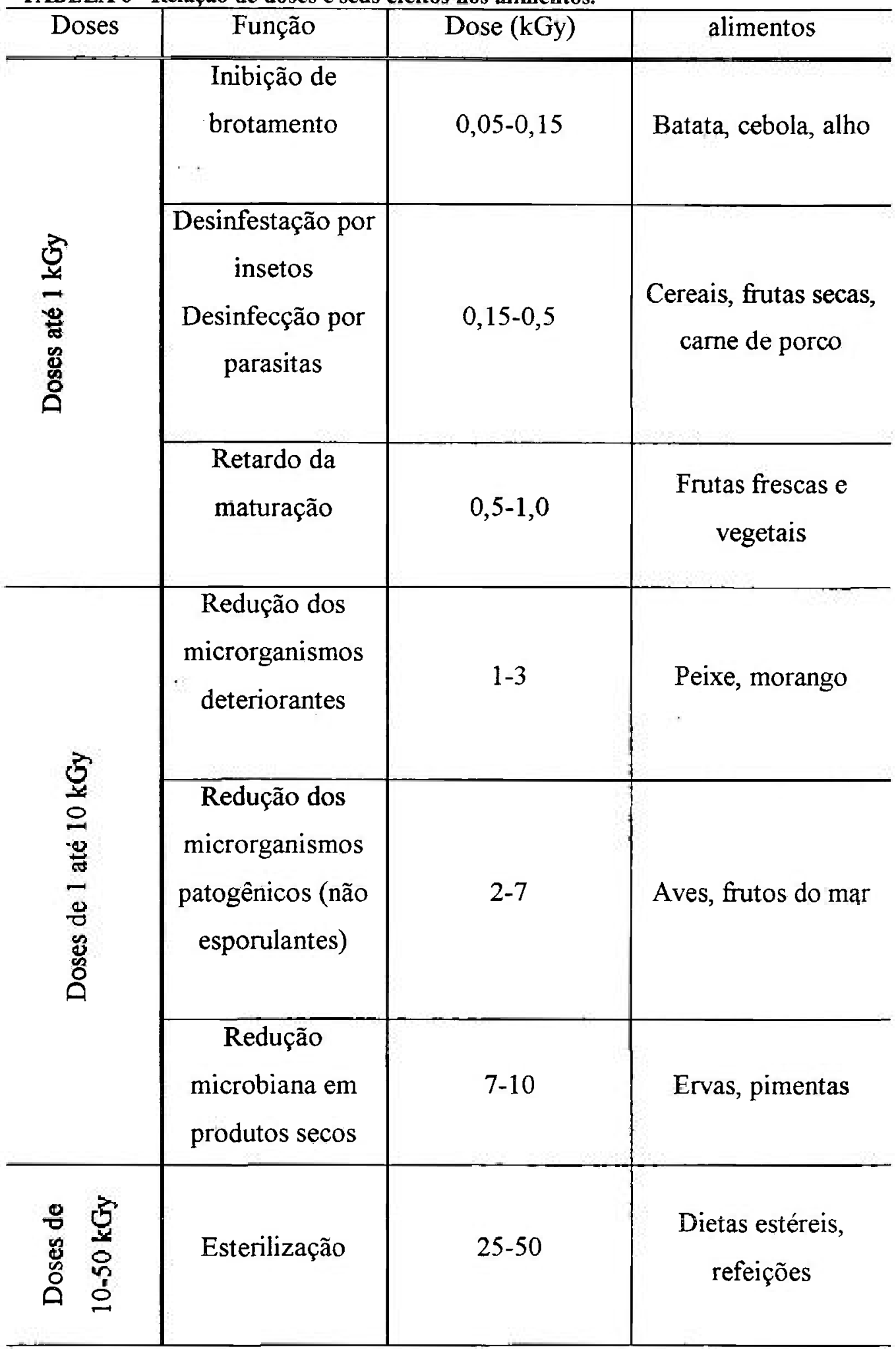

Fonte: Kilcast, 1995. 


\subsection{Detecçáo de alimentos irradiados}

A partir de meados de 1980 esforços foram direcionados para o desenvolvimento de métodos para detecção de alimentos irradiados, até então a preocupação era com a salubridade destes alimentos. $O$ material mais vasto foi obtido pela união da FAO (Food and Agriculture Organization) e da IAEA (International Atomic Energy Agency) através do programa de métodos analíticos para deteç̧ão de alimentos tratados com irradiação e pelo programa europeu: Community Bureau of Reference (BCR) que patrocinaram estudos colaborativos nos métodos mais promissores (Henon, 1995; Stevenson \& Stewart, 1995; Delincée, 1998).

O desenvolvimento destes métodos analíticos foi impulsionado pelo progresso na comercialização dos processos de irradiação, o comércio internacional de produtos irradiados, a regulamentação para o uso desta tecnologia em vários países e a demanda do consumidor para uma rotulagem adequada dos alimentos (Stevenson \& Stewart, 1995). Oponentes à irradiação de alimentos insistem na necessidade do estabelecimento de métodos de detecção para proteger os consumidores dos riscos que podem resultar este processo, mesmo após décadas de pesquisa comprovando a segurança da irradiação (Ranken et al., 1993; Kilcast, 1995; Diehl, 2002; Camargo, 2004).

A irradiação causa alterações mínimas na aparência e composição dos alimentos, o que torna dificil estabelecer se o alimento foi irradiado ou não. As mudanças químicas geradas pela dose recebida de energia ionizante devem ser características da irradiação e estáveis a futuros tratamentos, incluindo a armazenagem (Ranken et al., 1993; Kilcast, 1995; Diehl, 2002; Camargo, 2004).

As características técnicas e práticas para um método de detecção ideal são: especificidade para a irradiação e não ser influenciados por outros processos ou armazenagem, exatidão e reprodutibilidade, confiabilidade, sensibilidade, necessitar de pequenas quantidades de amostras, não envolver o uso de equipamentos sofisticados e caros, ter um limite de deteç̧ão abaixo da dose mínima aplicada nos alimentos, deve ser aplicável a grande quantidade de alimentos, fácil e rápido de ser realizado, capaz de estimar a dose de irradiação, além de permitir a identificação de ingredientes irradiados presentes em alimentos compostos (Stevenson \& Stewart, 1995).

É difícil preencher a todos estes requerimentos de um método ideal e não existe um método geral aplicável a todos os alimentos. Assim, uma série de métodos, baseados em mudanças físicas, químicas, microbiológicas e biológicas, foram desenvolvidos para 
ampliar a probabilidade de deteç̧ão e a confiabilidade nos resultados. A maior dificuldade encontra-se em detectar os alimentos que possuem apenas um dos componentes irradiados, muitas vezes torna-se necessário a utilização de mais de um método para a correta identificação, pois a irradiação gera alterações muito pequenas e similares a outras técnicas de preservação de alimentos (Stevenson \& Stewart, 1995; Delincée, 1998).

O estudo prolongado de métodos que permitam a detecção de alimentos irradiados em muitos países gerou o desenvolvimento das seguintes técnicas: Ressonânica paramagnética eletrônica (ESR), termoluminescência, formação de compostos voláteis gerados pela quebra de lipídeos e formação de 2-alquilciclobutanonas (Ranken \& Kill, 1993; Kilcast, 1995; Stevenson \& Stewart, 1995; Diehl, 2002; Camargo, 2004).

A ressonância paramagnética eletrônica (ESR) mede pequenas concentrações de radicais produzidos em uma matéria sólida, com, por exemplo, ossos. Os radicais formados permanecem imobilizados dentro da matriz, até meses após a irradiação. Este método é limitado à alimentos contendo ossos, como aves e peixe, podendo ser aplicado em outros alimentos contendo uma matriz sólida (Kilcast, 1995). As vantagens da ESR é a grande quantidade de alimentos nos quais pode ser utilizada, não é uma técnica destrutiva, e combina simplicidade, especificidade e medidas rápidas (Delincée, 1998), porém a instrumentação é cara e necessita a operação de um especialista (Kilcast, 1995).

A Termoluminescência baseia-se na emissão de luz sobre aquecimento de produtos como ervas e temperos. A energia gerada pela irradiação fica armazenada na estrutura cristalina sendo eliminada através de calor. Nos alimentos estes cristais estão presentes nos fragmentos de materiais contendo silicato (poeira). Estes minerais são isolados dos alimentos e a energia armazenada é liberada por aquecimento controlado emitindo luz que é medida através de um contador sensível a fótons. A técnica é trabalhosa, uma vez que os minerais devem ser separados da matéria orgânica. Os leitores de termoluminescência são caros, mas apresentam a vantagem de classificar de maneira inequívoca as amostras irradiadas das não irradiadas (Delincée, 1998). Este método foi estudado extensivamente, mas dúvidas permanecem devido a produção de alguns resultados falso-positivos (Kilcast, 1995).

Outro método promissor é a aplicação da luminescência foto estimulada (PSL) seu uso é limitado pela disponibilidade dos instrumentos. A técnica é similar a termoluminescência, porém usa a luz ao invés do calor para liberar a energia armazenada. Em vários laboratórios o uso desta técnica tem oferecido bons resultados. Este método é 
mais eficiente que a termoluminescência para detectar componentes irradiados presentes em uma mistura (Delincée, 1998).

O método resultante da detecção de produtos originários da quebra de lipídeos presentes nas aves é adequado para todos os alimentos contendo gorduras, mesmo em pequenas quantidades e mostrou-se adequado para detectar ovos irradiados. $O$ método envolve $o$ isolamento da gordura, separação da fração contendo hidrocarbonetos por cromatografia de adsorção e caracterização dos hidrocarbonetos por cromatografia gasosa. Embora, os hidrocarbonetos sejam formados por outros tratamentos de alimentos o perfil de distribuição quantitativa é característico após a irradiação (Delincée, 1998).

O teste de cometa verifica fragmentações do DNA, já que está molécula é grande e um alvo fácil para a radiação ionizante. Este método é restrito a alimentos que não sofreram aquecimento ou outro tipo de tratamento que induzem a fragmentação do DNA. As vantagens deste método é a simplicidade, baixo custo e rapidez da medida. (Delincée, 1998). Os métodos baseados em mudanças de DNA podem ter uma aplicação mais geral, mais requerem mais desenvolvimento (Kilcast, 1995).

A irradiação provoca alteração nas macro-moléculas principalmente pela despolimerização ou agregação. Estas mudanças contribuem para a alteração da viscosidade da solução, portanto essa propriedade físico-química pode ser utilizada como parâmetro para a verificação se determinado alimento foi irradiado ou não. (Kilcast, 1995).

Outro método citado na literatura é a detecção das ciclobutanonas por espectrometria de massa após separação por cromatografia gasosa. Não há evidências que este composto possa ser detectado em alimentos não irradiados (Delincée, 1998).

\subsection{Radiólise da água}

As alterações químicas sofridas pelo alimento irradiado são induzidas pela ação direta nos macro e micro nutrientes presentes no alimento, ou uma ação indireta provocada por intermediários reativos formados pela radiólise da água (Oh et al., 2004).

Nos alimentos com conteúdo entre $60-90 \%$ de água, a radiação ionizante é absorvida pelo composto em maior concentração, ou seja, a água, provocando a formação dos radicais: hidroxilas $(\mathrm{OH})$, elétrons solvatados $\left(\mathrm{e}_{\mathrm{aq}}\right)$, átomos de hidrogênio $\left(\mathrm{H}^{\circ}\right)$, hidrogênio molecular $\left(\mathrm{H}_{2}\right)$ e peróxido de hidrogênio $\left(\mathrm{H}_{2} \mathrm{O}_{2}\right)$ e estes radicais por sua vez irão interagir com os componentes dos alimentos, essa interação é denominada secundária 
ou indireta (Phillips, 1961; Schwarz, 1981; Muñoz et al, 1985; International Consultive Group on Food Irradiation, 1992).

Em alimentos secos, como especiarias e grãos, e alimentos em que a água foi removida por desidratação ou imobilizada por congelamento não sofrem o efeito secundário da irradiação, nestes casos os efeitos da irradiação são diretos ou primários. Isto é, a irradiação interage diretamente com os componentes presentes no alimento (International Consultive Group on Food Irradiation, 1992).

A formação dos átomos de hidrogênio e radicais hidroxilas ocorrem quando a radiação eletromagnética ou partículas carregadas interagem com a água, a ionização ocorre ao longo do caminho da partícula ou elétron primário de recuo. A cada ponto em que ocorre a retirada dos elétrons, os elétrons secundários formados possuem energia suficiente para futuras ionizações (retiradas de elétrons). Após $10^{-18}-10^{-16}$ segundos da passagem da partícula pode se resumir a reação que ocorre na água a seguir (Phillips, 1961):

$$
\mathrm{H}_{2} \mathrm{O}+\mathrm{e}_{1} \longrightarrow \mathrm{H}_{2} \mathrm{O}^{+}+\mathrm{e}_{2}+\mathrm{e}_{\mathrm{s}}
$$

Na qual:

$e_{1}$ e e $e_{2}$ : elétrons de recuo

$\mathrm{e}_{\mathrm{s}}$ : elétron secundários

Os elétrons secundários, também, podem iniciar processos de ionização (Phillips, 1961):

$$
\mathrm{H}_{2} \mathrm{O}+\mathrm{e}_{\mathrm{s}} \longrightarrow \mathrm{H}_{2} \mathrm{O}^{+}+\mathrm{e}_{\mathrm{s} 1}+\mathrm{e}_{\mathrm{s}}
$$

A água ionizada é convertida no radical hidroxila em $10^{-12}$ segundos (Phillips, 1961).

$$
\mathrm{H}_{2} \mathrm{O}^{+}+\mathrm{H}_{2} \mathrm{O} \longrightarrow \mathrm{H}_{3} \mathrm{O}^{+}+{ }^{-} \mathrm{OH}
$$

A formação dos átomos de hidrogênio se dá pela captura de um elétron secundário pela água que leva a formação de $\mathrm{H}_{2} \mathrm{O}^{-}$, que através da reação a seguir produz hidrogênio (Phillips, 1961).

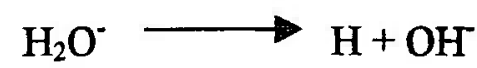


A radiólise da água pode ser resumida pelas reações apresentadas a seguir (Phillips, 1961).

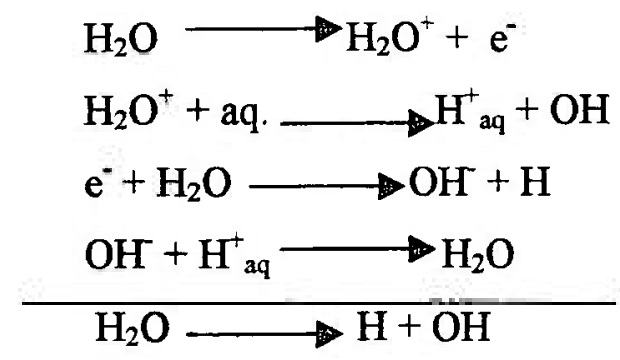

As espécies formadas ( $\mathrm{OH}, \mathrm{e}_{\mathrm{aq}}^{-}$e $\left.\mathrm{H}\right)$ são bastante reativas, portanto duram pouco tempo em solução. $\mathrm{O}$ radical hidroxila é uma gente oxidante, enquanto o elétron aquoso e o átomo de hidrogênio são agentes redutores (Phillips, 1961).

A formação do hidrogênio e do peróxido de hidrogênio ocorre por combinação dos radicais anteriormente citados. Estas reações acontecem $10^{-7}$ segundos após a passagem das partículas carregadas. As reações estão demonstradas a seguir (Phillips, 1961).

$$
\begin{aligned}
& \mathrm{H}+\mathrm{H} \longrightarrow \mathrm{H}_{2} \\
& \mathrm{OH}+\mathrm{OH} \longrightarrow \mathrm{H}_{2} \mathrm{O}_{2}
\end{aligned}
$$

\subsection{Efeito da radiação em carboidratos}

Os carboidratos são encontrados extensivamente em animais e plantas e formam uma parte essencial dos alimentos (Phillips, 1972).

Os monossacarídeos são as formas mais simples de carboidratos, enquanto que os oligossacarídeos são compostos por vários monossacarídeos. Estes são formados pela eliminação de uma molécula de água entre dois grupos hidroxilas para formar uma ligação glicosídica. A hidrólise de um oligossacarídeo gera os monossacarídeos os quais originalmente era composto (Shallenberger \& Birch, 1975).

Os produtos radiolíticos provenientes de carboidratos consistem principalmente de ácidos e compostos carbonílicos (Bothner-by \& Balazs, 1957; Villavicencio, 1998). Ocorre também a formação de malonaldeído e deoxi açúcares, porém a formação destes compostos está relacionada ao $\mathrm{pH}$ da solução, que deve ser alcalino, portanto como a 
maioria dos alimentos apresenta $\mathrm{pH}$ ácido estes compostos não são facilmente encontrados (Scherz, 1970; International Consultive Group on Food Irradiation, 1992).

A irradiação de carboidratos é importante, pois provoca a quebra de polissacarídeos com a formação de compostos de massa molecular específica, que acabam por ter várias aplicações no processamento de alimentos, como estabilizante e espessantes, como é o caso da quitosana e do alginato de sódio (Ulanski \& Rosiak, 1992; Waisikiewicz et al., 2005). Na literatura há poucos trabalhos que descrevem os produtos formados com a irradiação de açúcares e muitos deles são trabalhos das décadas de 60, 70 e 80, alguns deles são citados extensivamente ao longo desta tese, pois constituem trabalhos de referência até os dias de hoje, como é o caso de Phillips, 1961; Phillips, 1972 e Sonntag, 1980

A radiação de soluções pode agir no solvente e no soluto, dependendo da concentração da solução. Em soluções aquosas, o efeito mais importante provocado pela irradiação é a radiólise da água com a formação de radicais, como a hidroxila. Este radical é o mais importante quando se trata de carboidratos, a sua função é retirar os hidrogênios ligados ao átomo de carbono. A radiação em soluções de carboidratos leva à alterações de $\mathrm{pH}$, rotação óptica, poder redutor, viscosidade e espectro de ultravioleta. Os produtos formados a partir de açúcares irradiados em fonte de cobalto-60 e em acelerador de elétrons são semelhantes, porém a atmosfera em que ocorre a irradiação, o valor do $\mathrm{pH}$, a temperatura da amostra, o conteúdo de água do alimento e a dose irradiada são fatores que podem afetar os produtos formados (Desrosier \& Rosenstock, 1960; Phillips, 1961; Diehl et al., 1978; Josephson \& Peterson, 1983; Deeble et al., 1991; Gray \& Mower, 1991; International Consultive Group on Food Irradiation, 1992; Vieira \& Del Mastro, 2002; Waisikiewicz et al., 2005).

A literatura, em geral, apresenta os efeitos da irradiação em mono e polissacarídeos presentes sozinhos em solução ou no estado sólido a fim de facilitar a identificação e o estudo dos produtos resultantes. Nos alimentos, estes carboidratos encontram-se em conjunto com proteínas e outros compostos que podem interferir nos produtos formados após a irradiação (Diehl et al., 1978). A presença de ácido ascórbico na solução a ser irradiada protege o carboidrato dos efeitos da irradiação (Aliste \& Del Mastro, 2004). Suco de maçã irradiado resultou em apenas $1,64 \%$ da glicose inicial degradada em compostos ácidos (Bara, 1973).

A irradiação de monossacarídeos em atmosfera de oxigênio ou sob vácuo indica que todas as ligações das moléculas podem ser afetadas. A oxidação ocorre nas 
extremidades das moléculas e a quebra das ligações leva a formação de fragmentos menores (Phillips, 1972).

No caso das aldoses, em especial da glicose irradiada na ausência de oxigênio todos os seis possíveis radicais glicosilas podem ser formados, como pode ser observado na FIG. 7. Na irradiação em presença de oxigênio, os radicais glicosilas são convertidos nos radicais peroxilas correspondentes, mostrados na FIG. 8. E os produtos decorrentes das reações destes radicais, nestas duas atmosferas, estão apresentados na TAB. 7 (Sonntag, 1980).
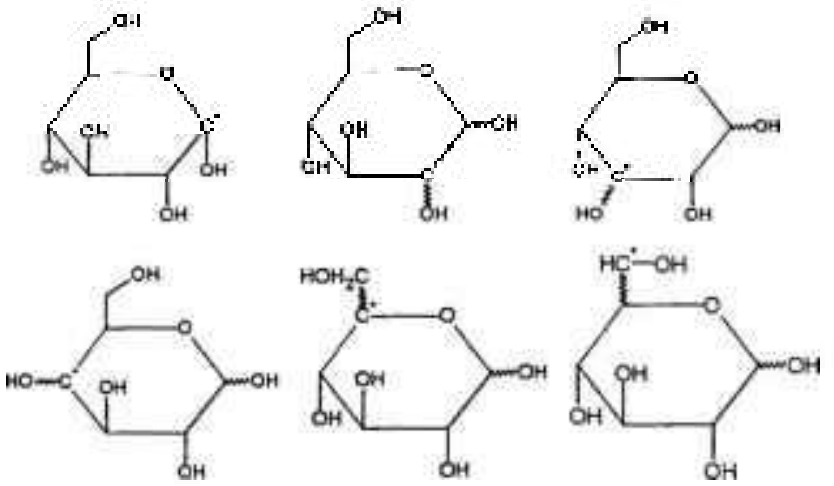

FIGURA 7 - Radicais glicosilas formados após a irradiação da glicose na ausência de oxigênio. Fonte: Sonntag, 1980.
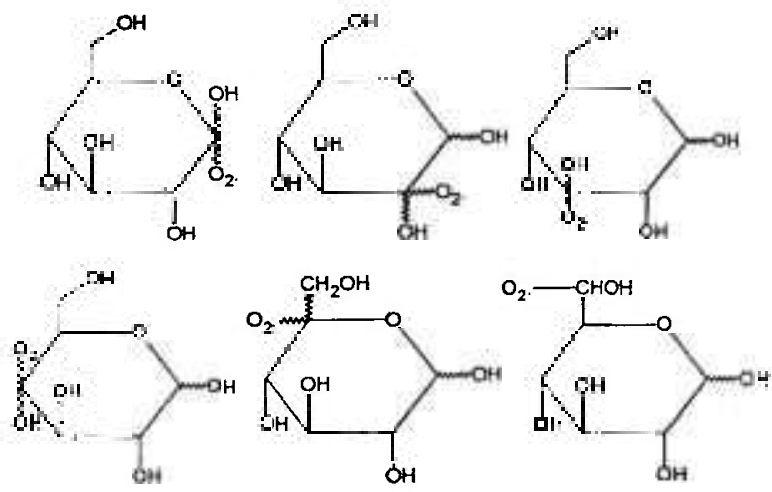

FIGURA 8 - Radicais peroxilas formados após a irradiação da glicose na presença de oxigênio. Fonte: Sonntag, 1980. 
TABELA 7 - Produtos derivados da solução de glicose após irradiação na presença de oxigênio e saturada $\mathrm{cam} \mathrm{\textrm {N } _ { 2 }}$ O (livre de oxigênio) em temperatura ambicntc

\begin{tabular}{|c|c|c|}
\hline Produto & $\begin{array}{c}\text { Valor de } \mathrm{G}^{*} \\
\text { atmosfera: } \mathrm{N}_{2} \mathrm{O}\end{array}$ & $\begin{array}{c}\text { Valor de } \mathrm{G}^{*} \\
\text { Atmosfera: } \mathrm{N}_{2} \mathrm{O} / \mathrm{O}_{2}\end{array}$ \\
\hline Acido D-glucônico & 0,15 & 0,90 \\
\hline D-arabino-Hexos-2-ulose (D-glucosona) & 0,15 & 0,90 \\
\hline D-ribo-Hexos-3-ulose & $\overline{0,10}$ & 0,57 \\
\hline D-xilo-Hexos-4-ulose & 0,075 & 0,50 \\
\hline D-xilo-Hexos-5-ulose & 0,18 & 0,60 \\
\hline D-gluco-Hexodialdose & 0,22 & 1,55 \\
\hline Ácido 2-Deoxi-D-arabino-hexonico & 0,95 & Ausente \\
\hline 5-Deoxi-D-treo-hexos-4-ulose & $\overline{0,08}$ & Ausente \\
\hline Ácido 5-Deoxi-D-xilo-hexonico & 0,08 & Ausente \\
\hline 2-Deoxi-D-eritro-hexos-5-ulose & 0,08 & Ausente \\
\hline 5-Deoxi-D-xilo-hexodialdose & $0, \overline{08}$ & Ausente \\
\hline 3-Deoxi-D-eritro-hexos-4-ulose & 0,25 & Ausente \\
\hline 3-Deoxi-D-eritro-hexos-2-ulose & 0,25 & Ausente \\
\hline 4-Deoxi-L-treo-hexos-5-ulose & 0,25 & Ausente \\
\hline 6-Deoxi-D-xilo-hexos-5-ulose & 0,05 & Ausente \\
\hline D-arabinose & 0,01 & 0,10 \\
\hline Ácido D-arabinônico & ausente & 0,10 \\
\hline D-ribose & $<0,005$ & Ausente \\
\hline D-xilose & $<0,005$ & 0,08 \\
\hline Xylo-Pentodialose & ausente & 0,08 \\
\hline 2-Deoxy-D-eritro-pentose & 0,04 & Ausente \\
\hline D-Eritrose & 0,01 & 0,02 \\
\hline Ácido D-Eritronico & ausente & 0,02 \\
\hline L-Treose & $<0,003$ & Ausente \\
\hline L-treo-Tetrodialdose & ausente & 0,20 \\
\hline 3-Deoxytetrulose & 0,02 & $\overline{\text { Ausente }}$ \\
\hline 1,3-Dihidroxi-2-propanona & 0,03 & Ausente \\
\hline Ácido glicérico & ausente & 0,13 \\
\hline Glioxal & ausente & 0,11 \\
\hline Ácido glicólico & ausente & $\overline{0,4}$ \\
\hline Formaldeido & - ausente & 0,12 \\
\hline Ácido fórmico & ausente & 0,6 \\
\hline
\end{tabular}

$\mathrm{G}=$ número de moléculas produzidas $/ 100 \mathrm{MeV}$ de energia absorvida.

Fonte: Sonntag, 1980. 
De acordo com Oh et al., 2006, outros ácidos são formados a partir da irradiação de soluções de açúcares como ácido deoxicetohexonico e ácido 2deoxiglucônico.

Estudos realizados em ratos mostraram que a alta concentração de glioxal diminui rapidamente a concentração de açúcar no sangue, provavelmente decorrente de sua ação irritante nas células pancreáticas (Berry et al., 1965).

As cetoses geram controvérsias na literatura. Phillips, 1961 reporta a frutose como agente protetor devido a sua propriedade de reagir preferencialmente com os radicais hidroxilas e hidrogênio formados durante a irradiação, enquanto Desrosier \& Rosenstock, 1960 relatam as cetoses como apresentando grande resistência a oxidação.

A irradiação da frutose em presença de oxigênio leva a formação principalmente de D-Glucosona que é uma substância mutagênica. Os produtos de radiólise obtidos constituem menos que $1 \%$ da frutose inicial, mesmo em doses de $20 \mathrm{kGy}$ (Drijver \& Holzapfel, 1986). Em condições aneróbicas, os produtos resultantes principais são os deoxi açúcares e açúcares com dois grupamentos carbonilas (Adam, 1983).

Em dissacarídeos, como a sacarose, a irradiação proporciona a quebra da ligação glicosídica com a formação dos monossacarídeos: glicose e frutose (Desrosier \& Rosenstock, 1960). Para a celobiose, 1/3 dos ataques efetuados pelo radical hidroxila levou a quebra da ligação glicosídica, enquanto que $2 / 3$ dos ataques resultou em produtos que mantiveram a estrutura de 12 carbonos da celobiose, ou produtos com maior número de carbonos, por exemplo, 24 carbonos (Adam, 1983).

$\mathrm{Na}$ irradiação sob vácuo, os vários radicais de açúcar formados, contendo de 2 a 3 fragmentos de carbono podem dimerizar e levar a formação de compostos de cadeia longa. A taxa de formação destes polímeros é diretamente proporcional a dose recebida (Grant \& Ward, 1959; Phillips, 1961; Snell,1965).

A irradiação de goma arábica em soluções concentradas e na presença de ar leva a formação de compostos poliméricos e em soluções diluidas leva a degradação do produto. Nas soluções diluídas, o processo principal é a radiólise da água, com a hidroxila sendo a espécie reativa produzida mais importante. A hidroxila abstrai um hidrogênio do carboidrato para dar um radical livre. $\mathrm{O}$ radical formado é instável e tem pouca chance de encontrar outro radical em solução diluída, assim a goma arábica degrada. Em soluções concentradas, a radiação age sobre o carboidrato, a alta concentração da solução contribui para a reação entre os radicais de carboidratos formados, resultando em compostos de 
cadeia longa. A formação de polímeros ocorre tanto na radiação por feixe de elétrons como na radiação gama (Barker et al., 1959; Katayama et al., 2006).

\subsection{Radiação gama e por feixe de elétron}

A radiação gama leva a energia ao produto a ser irradiado através de fótons, que corresponde a radiação eletromagnética de alta freqüência. A energia do fóton está relacionada ao elemento radioativo escolhido para liberar a radiação gama. A radiação gama pode ser produzida por duas fontes: o cobalto-60 e o césio-137. $\mathrm{Na}$ indústria, a fonte de radiação gama é o cobalto-60 $\left({ }^{60} \mathrm{Co}\right) . \mathrm{O}{ }^{137} \mathrm{Cs}$ é pouco utilizado como fonte de raios gama, sua maior fonte reside em residuo nuclear não processado, e não há capacidade de reprocessamento requerido para esta fonte. Para processar a mesma quantidade de produto, na mesma dose é necessária maior atividade de césio que cobalto. $O$ césio-137 constitui um risco a saúde por ser solúvel em água, facilitando a contaminação deste recurso natural (Lagunas Solar \& Matthews, 1985; Kilcast, 1995; Deeley, 2004).

A legislação brasileira restringe a energia das fontes de radiação para o tratamento dos alimentos a fim de evitar a indução de radioatividade nos produtos tratados. As fontes de radiação autorizadas são: raios gama proveniente do radionuclídeo ${ }^{60} \mathrm{Co}$ ou fonte de ${ }^{137} \mathrm{Cs}$, raios $\mathrm{X}$ gerados por máquinas que trabalham com energias de até $5 \mathrm{MeV}$ ou elétrons gerados por máquinas que trabalham com energias até $10 \mathrm{MeV}$ (Brasil, 2001).

$A$ atividade no irradiador gama é dada em Curie ( $1 \mathrm{Ci}=3,7 \times 10^{10}$ Becquereis). $\mathrm{O}$ ${ }^{60} \mathrm{Co}$ decaí para o elemento não radioativo Niquel-60 através da emissão de partículas beta $(\beta)$, mais dois fótons de energia gama $(\gamma)$, medidos em $\mathrm{MeV}$, como pode ser observado na reação a seguir (Lagunas Solar \& Matthews, 1985; Deeley, 2004):

$$
{ }_{27}^{60} \mathrm{Co} \rightarrow{ }_{28}^{60} \mathrm{Ni}+(\beta-)+\gamma(1,17 \mathrm{MeV})+\gamma(1,33 \mathrm{MeV})
$$

A partícula beta é um elétron que se locomove na velocidade da luz. As paredes da cápsula, em que fica armazenado o material radioativo é suficiente para parar essas partículas, enquanto que os raios gama com seu alto poder de penetração conseguem atingir o produto (Deeley, 2004).

A meia-vida do ${ }^{60} \mathrm{Co}$ é de 5,271 anos. Após este período de tempo, 50\% da atividade do radionuclídeo presente no inicio terá decaído (Deeley, 2004). 
A fonte de radiação gama age isotropicamente, isto é os fótons partem em todas as direções igualmente. A eficiência da utilização da fonte gira em torno de $20-30 \%$, portanto haverá pontos em que não haverá produto para receber a dose, como por exemplo, o espaço morto acima e abaixo da fonte, assim como os fótons que atravessam o produto e continuam a ter atividades do lado oposto, atingindo as paredes do local em que está instalada a fonte. A taxa de dose para a radiação gama é dada em $\mathrm{kGy} / \mathrm{h}$. Estimativas para a construção de uma planta de radiação gama estão em torno de 2-10 milhões de dólares, dependendo da capacidade de processamento, atividade da fonte e do nível de automação. Fontes com atividade total de $1 \mathrm{MCi}$ apresentam o custo médio de 3-4 milhões de dólares. O maior custo está relacionado ao fornecimento constante de ${ }^{60} \mathrm{Co}$, já que seu decaimento é de aproximadamente 12\% ao ano (Lagunas Solar \& Matthews, 1985; Deeley, 2004).

A exposição do alimento e da embalagem ao ${ }^{60} \mathrm{Co}$ não induz radioatividade, porque a energia de suas emissões (em média 1,25 MeV) está abaixo da energia limite para os fótons induzirem reações nucleares (Lagunas Solar \& Matthews, 1985; Kilcast, 1995).

$\mathrm{O}$ estoque mundial de ${ }^{60} \mathrm{Co}$ é de aproximadamente $75 \mathrm{MCi}$ e está direcionado para atender processos terapêuticos e a esterilização de produtos médicos. Este estoque permitiria o processamento de 1250 toneladas de alimento/h a $1 \mathrm{kGy}$. $\mathrm{O}$ césio contribui com a atividade de $90 \mathrm{MCi}$ o que propiciaria o processamento de 350 toneladas de alimento/h com a mesma dose (Lagunas Solar \& Matthews, 1985).

No acelerador de elétrons a potência é dada em Watts. A eficiência da utilização da potência gira em torno de $25-40 \%$ dependendo da aplicação e dos detalhes do design do equipamento. $\mathrm{O}$ feixe de elétrons é uma fonte altamente direcional, contudo a energia não é constante ao longo do feixe de elétrons, pois ocorrem perdas. As perdas são decorrentes da passagem do feixe direto pelo produto, pelas extremidades da embalagem e pelo espaço morto entre os produtos na esteira. A taxa de dose no feixe de elétrons é mais alta que na radiação gama sendo expressa em $\mathrm{kGy} / \mathrm{s}$. Uma acelerador de elétron com energia equivalente a 1MCi custa em torno de 1 a 1,5 milhões de dólares (Lagunas Solar \& Matthews, 1985; Deeley, 2004).

A maior diferença entre a radiação por feixe elétrons e a radiação gama é o poder de penetração. $O$ feixe de elétrons apresenta cargas aumentando a probabilidade de colisão com os elétrons do produto, reduzindo a capacidade de penetração, porém com taxa de dose de radiação alta. Em alimentos com alto teor de umidade irradiados com elétrons de $10 \mathrm{MeV}$ a espessura limite de penetração é de $3,9 \mathrm{~cm}$. Na radiação gama, os fótons não apresentam cargas o que reduz as interações com os elétrons do produto, resultando em 
alto poder de penetração e baixa taxa de dose (International Consultive Group on Food Irradiation, 1992; Kilcast, 1995; Deeley, 2004; Farkas, 2006).

O objetivo da irradiação de um produto é fornecer a mínima dose para se obter a redução de patógenos desejada, qualquer valor acima do estipulado pode gerar danos ao produto. Na irradiação com elétrons, estes ao se moverem carregam momento que geram elétrons secundários logo abaixo da superficie do produto, assim a dose recebida logo abaixo da superficie é maior que a dose aplicada ao produto (Deeley, 2004).

Enquanto a irradiação usando cobalto-60 está difundida, com mais de 170 irradiadores em escala industrial no mundo todo, o surgimento do acelerador de elétron pode trazer um alento à irradiação de alimentos, pois não necessita de uma fonte radioativa. A máxima eficiência do acelerador de elétrons é obtida com a sua instalação na linha de prođução do produto a ser irradiado (Loaharanu, 1994).

A TAB. 8 apresenta uma comparação entre a radiação gama e o feixe de elétrons. A radiação gama por usar uma fonte radioativa apresenta a desvantagem de não permitir o seu desligamento, apesar deste fato, nos últimos 30-40 anos, aproximadamente, $40 \%$ dos equipamentos médicos foram esterilizados com radiação gama. A irradiação por feixe de elétrons apresentou crescimento nos EUA pela aceitação do mercado em consumir bife irradiado por esta tecnologia. O processamento por feixe de elétrons e radiação gama apresentam efeitos equivalentes na irradiação de alimentos (Grünewald, 1983; Deeley, 2004; Farkas, 2006)

Em instalações industriais, a escolha em geral é pelo acelerador de elétrons, pois sua instalação é mais simples que uma fonte de radionuclídeos. Além disso, permite seu desligamento que é uma característica favorável em caso de falhas no sistema ou problemas durante o processamento. A fonte de radiação gama e os aceleradores industriais de elétrons de média e alta energia requerem proteção completa, em concreto, a sua volta a fim de proteger o meio ambiente, os trabalhadores e indíviduos do público. (Lagunas Solar \& Matthews, 1985; Kilcast, 1995).

Uma terceira fonte de radiação são os raios $\mathrm{X}$, gerados a partir de um bombardeamento de elétrons em um alvo de metal. Embora essa tecnologia seja comum em hospitais, no momento ela não está sendo utilizada na radiação de alimento por causa da baixa eficiência na conversão dos elétrons para os raios $X$. Os raios $X$ permitem a alta penetração além de ser uma tecnologia que pode ser desligada (Kilcast, 1995; Deeley, 2004). 
TABELA 8 - Comparação entre os parâmetros funcionais primários que diferenciam radiação gama, feixe de elétrons e raios $\mathbf{X}$

\begin{tabular}{c|c|c|c}
\hline & Radiação Gama & Feixe de elétrons & Raios X \\
\hline Liga/desliga & não & sim & sim \\
\hline $\begin{array}{c}\text { Espessura de } \\
\text { penetração }\end{array}$ & $50-80 \mathrm{~cm}$ & $5-8 \mathrm{~cm}$ & $50-80 \mathrm{~cm}$ \\
\hline Taxa de dose & $\mathrm{kGy} / \mathrm{h}$ & $\mathrm{kGy} / \mathrm{s}$ & $\mathrm{kGy} / \mathrm{s}$ \\
\hline $\begin{array}{c}\text { Homogeneidade da } \\
\text { dose }\end{array}$ & alta & baixa & alta \\
\hline
\end{tabular}

Fonte: Deeley, 2004

Um resumo das fontes de radiação e suas características estão apresentados na TAB. 9.

TABELA 9 - Características das fontes de radiação. Fonte: Adaptado de Kilcast, 1995.

\begin{tabular}{|c|c|}
\hline Fonte de radiação & Características da fonte de radiação \\
\hline \multirow{5}{*}{ Cobalto-60 } & Alto poder de penetração \\
\hline & Fonte radioativa permanente \\
\hline & Alta eficiência \\
\hline & Necessário o recarregamento do irradiador \\
\hline & Baixo número de amostras \\
\hline \multirow{6}{*}{ Feixe de elétrons } & Baixo poder de penetração \\
\hline & $\begin{array}{l}\text { Tecnologia que permite o desligamento e a } \\
\text { instalação em linha de produção }\end{array}$ \\
\hline & Alta eficiência \\
\hline & Alta taxa de dose \\
\hline & Necessário resfriamento \\
\hline & Tecnicamente complexo \\
\hline \multirow{6}{*}{ Raios X } & Alto poder de penetração \\
\hline & Tecnologia que permite o desligamento \\
\hline & $\begin{array}{c}\text { Baixa eficiência de conversão entre } \\
\text { elétrons e raios } x\end{array}$ \\
\hline & Alta taxa de dose \\
\hline & Necessário resfriamento \\
\hline & Tecnicamente complexo \\
\hline
\end{tabular}




\subsection{Legislação para alimentos irradiados}

No Brasil, as normas gerais que regulamentam a irradiação dos alimentos foram aprovadas através do Decreto Lei $\mathrm{n}^{0} 72$ 718, de 29 de agosto de 1973, e complementadas pela Portaria $n^{0}$ 09-DINAL do Ministério da Saúde, de 08 de março de 1985 e, posteriormente, pela Portaria $n^{0}$ 30-DINAL do Ministério da Saúde, de 25 de setembro de 1989 (Brasil, 1973; Brasil, 1985; Brasil, 1989; Souza, 2000). Ambas as portarias foram revogadas pela RDC, de 21 de janeiro de 2001.

O Decreto lei de 1973 dispunha sobre a elaboração, armazenamento, transporte, distribuição, importação, exportação e exposição à venda ou entrega ao consumo de alimentos irradiados. Neste decreto, a Comissão Nacional de Energia Nuclear era responsável por baixar instruções disciplinando o registro de equipamentos destinados às operações de irradiação, as condições de funcionamento e os processos tecnológicos a serem observados pelos estabelecimentos licenciados. Os alimentos irradiados deveriam ser acompanhados de relatório firmado pela responsável pela operação de irradiação do alimento, no qual indicava: a finalidade da irradiação, fonte energia e dose de irradiação, detalhes das condições ambientais reinantes durante a irradiação, descrição de qualquer tratamento a que tenha sido submetido o alimento antes, durante e após a irradiação, tipo e natureza da embalagem empregada para acondicionar o alimento irradiado, condições e período de armazenamento propostos para o alimento irradiado. Os alimentos irradiados, quando expostos à venda, ou entregues ao consumo, deveriam trazer na respectiva embalagem e nos cartazes afixados nos locais de venda ou entrega ao consumo, a indicação: "Alimento Tratado por Processo de Irradiação" e a declaração: "Este produto foi processado em estabelecimento sob controle da Comissão Nacional de Energia Nuclear" (Brasil, 1973).

A Portaria $n^{0} 9$, aprovada em 08 de março de 1985, pela Divisão Nacional de Vigilância Sanitária de Alimentos do Ministério da Saúde (DINAL) estabelecia as normas gerais para irradiação de alimentos, como o propósito do tratamento, tipo e nível de energia da fonte de irradiação, dose média de radiação a ser empregada em cada processo e a relação dos alimentos. De acordo com essa norma, a dose média de radiação não podia exceder à $10 \mathrm{kGy}$ com a finalidade de assegurar a inocuidade do alimento irradiado, sob os pontos de vista toxicológico, nutricional e microbiológico. Era proibida a irradiação de um alimento que já fora irradiado. Em relação ao rótulo, a portaria estabelecia que os alimentos irradiados deveriam trazer além dos dizeres exigidos para os alimentos em geral, 
a expressão: "Alimento Tratado por Processo de Irradiação". Quando exposto à venda, um cartaz, placa, ou equivalente deverá ser fixado com a mesma declaração escrita. A DINAL exigia que na nota fiscal fosse indicado que o alimento foi irradiado (Souza, 2000).

A Portaria $\mathrm{N}^{0} 30$ da DINAL foi aprovada em 25 de setembro de 1989 e ampliava o número de alimentos que podiam ser irradiados e que não constavam da portaria $n^{0} 9$ (Villavicencio, 1998; Aquino, 2003).

A resolução RDC $\mathrm{n}^{0} 21$, de 26 de janeiro de 2001 da Agência Nacional de Vigilância Sanitária (ANVISA) estabelece os requisitos gerais para o uso da irradiação de alimentos com vistas à qualidade sanitária do produto final. $\mathrm{O}$ tratamento dos alimentos por irradiação deve ser realizado em instalações licenciadas pela autoridade competente estadual ou municipal ou do Distrito Federal mediante expedição de Alvará Sanitário, após autorização da Comissão Nacional de Energia Nuclear e cadastramento no órgão competente do Ministério da Saúde. As instalações devem ser projetadas de modo a cumprir os requisitos de segurança radiológica, eficácia e boas práticas de manuseio e dotadas de pessoal qualificado que possua capacitação e formação profissional apropriada, e atender às exigências da legislação vigente (Brasil, 2001).

Qualquer alimento poderá ser tratado por radiação desde que sejam observadas as seguintes condições: a dose mínima absorvida deve ser suficiente para alcançar a finalidade pretendida, a dose máxima absorvida deve ser inferior àquela que comprometeria as propriedades funcionais e/ou os atributos sensoriais do alimento (Camargo, 2004; Brasil, 2001).

A embalagem deve ter condições higiênicas aceitáveis, ser apropriada para o procedimento de irradiação, estar de acordo com a legislação vigente e aprovada pela autoridade sanitária competente. Na rotulagem dos alimentos irradiados, além dos dizeres exigidos para os alimentos em geral e específico do alimento, deve constar no painel principal: "Alimento Tratado por Processo de Irradiação", com as letras de tamanho não inferior a um terço $(1 / 3)$ da letra de maior tamanho nos dizeres de rotulagem. Quando um produto irradiado é utilizado como ingrediente em outro alimento, deve declarar essa circunstância na lista de ingredientes, entre parênteses, após o nome do mesmo (Camargo, 2004; Brasil, 2001).

A indústria que irradiar alimentos deve fazer constar ou garantir que conste a indicação de que o alimento foi tratado pelo processo de irradiação: nas notas fiscais quando os alimentos estiverem a granel, nas notas fiscais e nas embalagens quando os alimentos já estiverem embalados (Brasil, 2001). 
Nos locais de exposição à venda de produtos a granel irradiados deve ser afixado cartaz, placa ou assemelhado com a seguinte informação: "Alimento Tratado por Processo de Irradiação" (Brasil, 2001).

Os alimentos irradiados não devem ser submetidos a re-irradiação salvo algumas exceções (Brasil, 2001).

\subsection{Reologia}

A reologia é o estudo da deformação da matéria ou da mobilidade dos fluidos e está diretamente relacionada com a quantidade de água presente, sendo estudada através da medida da sua viscosidade ou seu inverso, a fluidez. A viscosidade de um fluido é a medida de resistência ao movimento, resultando em deformação gerada pela fricção interna que ocorre quando uma camada do fluido desliza sobre a outra (Howard, 1991; Lepki, 1998; Bobbio \& Bobbio, 2001; Santos, 2004).

A viscosidade é uma propriedade com grande importância na indústria de alimentos. $\mathrm{O}$ seu conhecimento permite a correta seleção de bombas e o dimensionamento das tubulações, válvulas e equipamentos que são utilizados no processamento de uma matéria-prima. A determinação da viscosidade permite o controle efetivo do açúcar invertido durante a sua produção, garantindo a qualidade do produto final. A literatura é escassa em trabalhos que apresentem estudos de viscosidade para este ingrediente (Lepki, 1998; Gratão et al., 2004).

Isaac Newton propôs um modelo para descrever a viscosidade de um fluido. Duas superficies paralelas de um fluido de área, A, separadas por uma distância, dx, movem-se na mesma direção, com velocidades $v_{1}$ e $v_{2}$, conforme mostrado na FIG. 9 (Howard, 1991; Lepki, 1998; Santos, 2004). A camada superior do fluido move-se com velocidade maior que a camada inferior, que apresenta velocidade nula. As camadas entre essas duas placas apresentam velocidades intermediárias. 


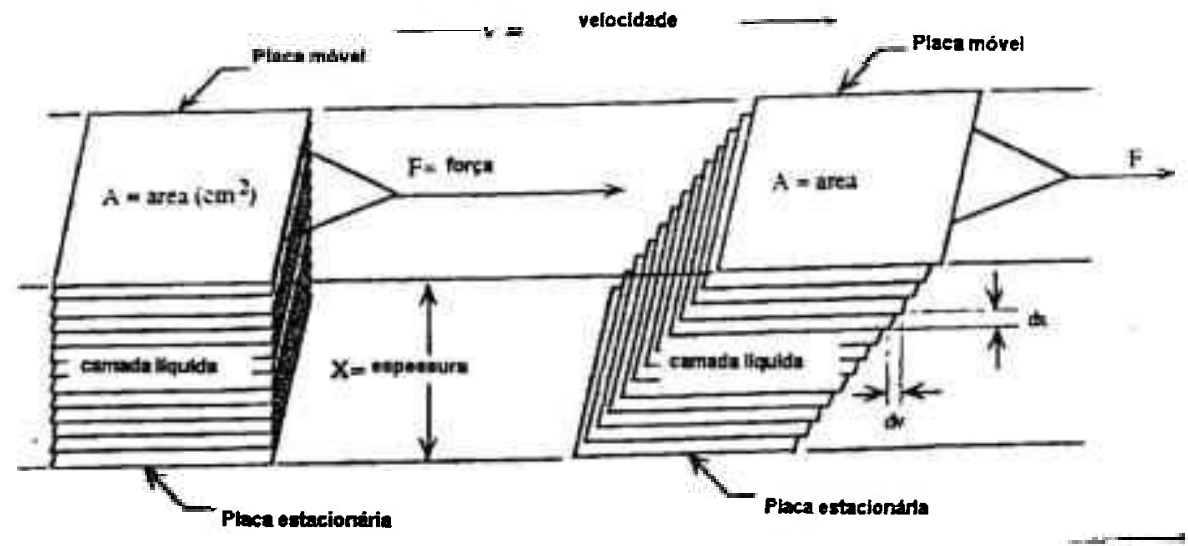

FIGURA 9 - Diagrama mostrando os fatores que são importantes no escoamento de um fluido newtoniano. Fonte: Howard, 1991.

Tendo como base esse modelo, a medida da viscosidade é a resistência ao movimento de várias camadas movendo-se com um gradiente de velocidade, $\mathrm{dv}$, quando sob ação de uma força $F$ (equação 1).

$$
\frac{F}{A}=\eta \cdot \frac{d v}{d x} \quad \text { Equação } 1
$$

Na qual:

$F=$ força

$\mathrm{A}=$ área

$\eta=$ viscosidade

$d v=$ variação de velocidade

$\mathrm{dx}=$ variação de espessura

O gradiente de velocidade, $\mathrm{dv} / \mathrm{dx}$, é a medida de velocidade na qual as camadas dos fluidos movem-se uma em relação às outras. Este gradiente é chamado de taxa de cisalhamento $(\gamma)$. A relação F/A recebe o nome de tensão de cisalhamento $(\sigma)$. Portanto, pode-se descrever a viscosidade como a relação entre a tensão de cisalhamento e a taxa de cisalhamento, apresentados na equação 2 (Lepki, 1998; Santos, 2004). 


$$
\eta=\frac{\sigma}{\gamma} \quad \text { Equaçåo } 2
$$
Na qual:
$\eta=$ viscosidade
$\sigma=$ tensão de cisalhamento
$\gamma=$ taxa de cisalhamento

A medida da viscosidade é realizada em viscosímetros que medem o torque necessário para rotacionar uma haste metálica cilíndrica (spindle) que é imersa no fluido. 0 spindle é acionado por um motor sincronizado através de uma mola calibrada que lhe imprime uma taxa de cisalhamento específica, a resistência do fluxo (viscosidade) é indicada pela deflexão da mola que é proporcional a velocidade de rotação do spindle, tamanho e forma geométrica (Santos, 2004).

A equação 2, para o cálculo da viscosidade, não inclui a temperatura como um de seuṣ parâmetros, porque a viscosidade é medida independente da temperatura, apesar da relação forte que existe entre esses dois termos. A viscosidade de um fluido é afetada inversamente pela temperatura, isto é a viscosidade diminui com o aumento de temperatura, assim o controle da temperatura é fundamental na medida da viscosidade (Howard, 1991).

A determinação da viscosidade dos alimentos permite sua divisão em fluido newtonianos e não-newtonianos. Os fluidos newtonianos são caracterizados pela viscosidade que independe da taxa de cisalhamento, como pode ser observado na FIG. 10 (Howard, 1991).

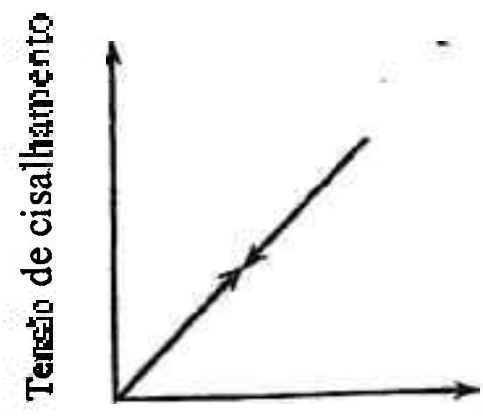

Taxa de cisalhamento

FIGURA 10 - Fluido Newtoniano. Fonte: Howard, 1991. 
Os fluidos não-newtonianos apresentam os valores de viscosidade dependente da taxa de cisalhamento, neste caso a viscosidade é denominada aparente (Howard, 1991). Os fluidos não-newtonianos podem ser classificados em:

- Pseudoplásticos: apresentam decréscimo na viscosidade com o aumento da taxa de cisalhamento. A FIG. 11, a seguir, mostra o comportamento deste fluido. As dispersões e as emulsões são exemplos destes fluidos (Howard, 1991, Bobbio \& Bobbio, 2001).

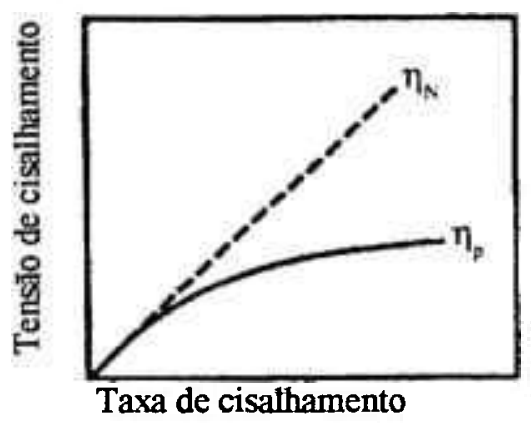

FIGURA 11 - Fluido pseudoplástico. $\eta_{\mathrm{n}}$ fluido newtoniano; $\eta_{\mathrm{p}}$ fluido plástico. Fonte: Bobbio \& Bobbio, 2001.

- Plásticos: são fluidos que sua forma não muda sem a ação de forças externas, sendo, portanto semelhantes a um sólido que pode escorrer quando sob tensão. Nestes fluidos, o movimento só começa quando a força aplicada excede um determinado valor, confrome mostrado na FIG. 12 (Bobbio \& Bobbio, 2001). Alimentos que apresentam esse comportamento são a maionese e o ketchup, ou seja, alimentos em que o escoamento é indesejável sob certas condições (Howard, 1991, Bobbio \& Bobbio, 2001).

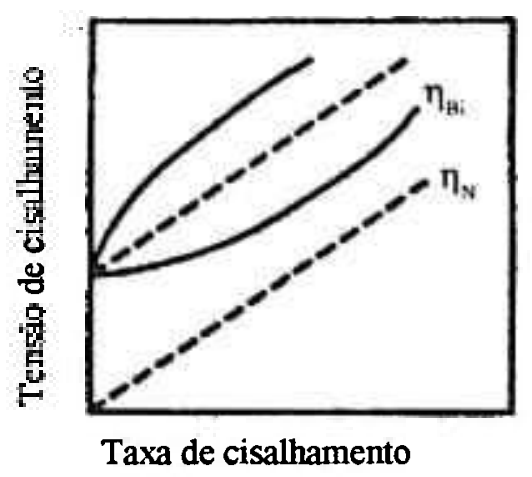

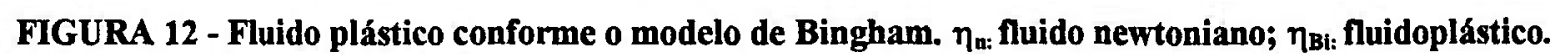
Fonte: Bobbio \& Bobbio, 2001. 
- Dilatantes: a viscosidade aparente aumenta por efeito de uma força aplicada ao fluido, ou seja, o fluido ao ser submetido à agitação aumenta sua resistência ao movimento voltando a viscosidade inicial ao cessar a aplicação desta força independente do tempo de aplicação desta força (FIG. 13). Exemplos: amido de milho em água dependendo da concentração (Howard, 1991, Bobbio \& Bobbio, 2001).

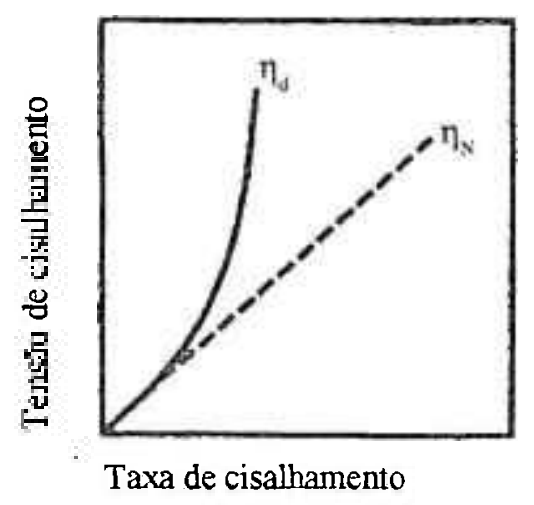

FIGURA 13 - Fluido dilatante. $\eta_{\mathrm{n}}$ : fluido newtoniano; $\eta_{\mathrm{d}}$ fluido dilatante. Fonte: Bobbio \& Bobbio, 2001.

- Tixotrópicos: estes fluidos perdem a viscosidade sob a ação de constante cisalhamento. Quando o cisalhamento pára retornam a sua viscosidade original, mas requerem tempo (FIG. 14). Exemplos: derivados da celulose e molho de tomate (Howard, 1991, Bobbio \& Bobbio, 2001).

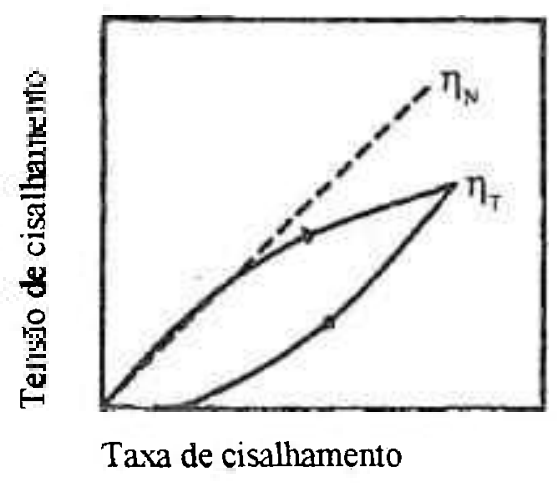

FIGURA 14 - Fluido tixotrópico $\eta_{n}$ : fluido newtoniano; $\eta$ t: fluido tixotrópico.

Fonte: Bobbio \& Bobbio, 2001. 


\section{MATERIAIS E MÉTODOS}

\subsection{Amostra}

O açúcar líquido invertido foi gentilmente cedido pela empresa DaBarra. As amostras processadas com raios gama e feixe de elétrons pertenciam a lotes diferentes, por esta razão nas análises físico-químicas apresentamos as análises do controle para as duas técnicas de irradiação utilizadas. O prazo de validade de cada uma das amostras era de 180 dias. As análises físico-químicas e microbiológicas foram realizadas nos laboratórios do Senai Mario Amato. A análise sensorial e a medida da viscosidade foram realizadas no laboratório de alimentos do CTR-IPEN.

\subsection{Irradiação}

A irradiação foi realizada com feixe de elétrons e raios gama, pertencentes ao Centro de Tecnologia das Radiações-IPEN. Nas irradiações com raios gama foi utilizado o irradiador Gammacell 220 (AECL, procedente do Canadá), que utiliza fontes de cobalto-60 colocados em lápis. Há 32 lápis dispostos ao redor da célula, onde fica posicionada a amostra, de forma a proporcionar um campo de radiação homogêneo no centro da câmara. A atividade foi de $3806,66 \mathrm{Ci}$ e a taxa de dose da fonte foi de $3,88 \mathrm{kGy} / \mathrm{h}(\mathrm{jan} / 2005)$ para as amostras utilizadas nas análises físico-químicas e 3,54 kGy/h (Ago/2005), para as amostras utilizadas no ensaio microbiológico. As amostras foram acondicionadas em frascos de vidro cuidadosamente fechados, com aproximadamente $400 \mathrm{~mL}$ de capacidade, e irradiadas em doses de 5, 10, 20,30 e $50 \mathrm{kGy}$.

As amostras irradiadas com raios gama, foram acompanhadas através da dosimetria para garantir a dose recebida. Os dosímetros utilizados para acompanhamento de irradiações são classificados como de rotina e devem ser considerados erros de no máximo 5\%. No caso, o dosímetro de rotina utilizado foi o Amber (Harwell Dosimeters, Inglaterra), fabricado com polimetilmetacrilato (acrílico) mais corantes e o Red-Perspex. 
Estes dosímetros tem sensibilidade de doses de 1 a $50 \mathrm{kGy}$. A dose recebida pelo dosímetro equivale à dose transferida para amostra. A leitura do dosímetro é feita em um espectrofotômetro.

O irradiador Gammacell foi calibrado e certificado pela Agência Internacional de Energia Atômica (AIEA). Através do serviço oferecido pela Agência, que recebe o nome de IDAS (Serviço Internacional de Garantia de Dose), no qual eles enviam um dosímetro de transferência de alanina, que é irradiado, e comparado com a resposta do dosímetro de rotina utilizado no laboratório. Se a resposta dos dosímetros apresentarem erro abaixo de 5\%, a Agência envia um certificado garantido a taxa de dose do irradiador em um determinado ponto de interesse.

Utilizou-se o acelerador de elétrons modelo Dynamitron-job188 fabricado pela Radiation Dynamics, com energia de 0,5 a $1,5 \mathrm{MeV}$, corrente de feixe de $0,3 \mathrm{~mA}$ a $25 \mathrm{~mA}$, potência de feixe máxima de $37,5 \mathrm{~kW}$ e varredura de feixe de 60 a $120 \mathrm{~cm}$, para irradiar as amostras nas doses de 5, 10, 20,30 e $50 \mathrm{kGy}$. Para as doses de 5 e $10 \mathrm{kGy}$, a corrente do feixe foi fixada em 2,74 mA e energia de 1,44 MeV. A bandeja foi levada ao feixe com velocidade que resultasse em uma taxa de dose de $11,19 \mathrm{kGy} / \mathrm{s}$, a amostra recebeu dose de $2,5 \mathrm{kGy}$ a cada passagem. As demais doses foram recebidas pela amostra no sistema de esteira, mas com corrente de feixe de $5,48 \mathrm{~mA}$ e energia de $1,44 \mathrm{MeV}$, proporcionando uma taxa de dose de $22,39 \mathrm{kGy} / \mathrm{s}$. A cada passagem pelo acelerador, a amostra recebeu a dose de $5 \mathrm{kGy}$. As amostras foram espalhadas em placas de petri com espessura de $3 \mathrm{~mm}$, para garantir que toda a amostra recebesse a dose média requerida. A superficie livre da placa foi envolta em filme plástico de PVC.

As amostras irradiadas no acelerador, também foram certificadas pela dosimetria, no caso, o dosímetro de rotina utilizado foi o de filme: CTA (Fuji Photo Film Co., Tokyo, Japan).

Todos os dosímetros utilizados para certificação das doses recebidas são calibrados no laboratório de Dosimetria em Processos de irradiação do IPEN-CTR e certificado pela AIEA.

\subsection{Análises físico-químicas}

As análises fisico-químicas foram realizadas em triplicata. Após a irradiação, as amostras utlizadas nos ensaios físico-químicos foram mantidas em geladeira (temperatura de $5^{\circ} \mathrm{C}$ ), até o momento da análise. 


\subsubsection{Reagentes}

Tartarato de sódio e potássio, sulfato de cobre, hidróxido de sódio e ácido clorídrico $37 \%$ foram adquiridos da Quimex; carbonato de sódio anidro da Cinética Química. Os demais reagentes, ferrocianeto de potássio, acetato de zinco, bissulfito de sódio e D-glicose anidra (dextrose) foram adquiridos da Synth. Todos os reagentes utilizados foram de grau PA.

\subsubsection{Equipamentos}

- Espectrofotômetro da Thermo Spectronic modelo Helios alpha;

- Banho ultrassônico Ney (modelo Got Heat);

- Refratômetro Carl Zeiss (modelo 1602 B);

- Banho-maria Dubnoff (modelo 304/D);

- Viscosímetro Brookfield (modelo LV-DVIII) acoplado com banho-maria Neslab.

\subsubsection{Densidade}

A densidade foi medida em picnômetros de 25 e $50 \mathrm{~mL}$, previamente calibrados. A calibração foi realizada com água destilada degaseificada através da fervura.

\subsubsection{Sólidos solúveis ( ${ }^{\circ} B$ rix) e índice de refração}

A determinação do grau Brix e do índice de refração foram realizadas em refratômetro Carl Zeiss (modelo 1602B). Algumas gotas do açúcar invertido foram dispostas no prisma do equipamento e esperou-se até o equilibrio de temperatura para realizar a leitura. Anotou-se a temperatura (44.1.04-C da AOAC, 2000).

A leitura de graus Brix e índice de refração foram corrigidas para a temperatura de referência de $20^{\circ} \mathrm{C}$. Como a amostra contém açúcar invertido deve-se aplicar o fator de correção de Whalley (F). A cada porcentagem de açúcar invertido ( $\mathrm{X}_{\text {inversão }}$ ) contido na amostra deve-se adicionar 0,022 ao valor de sólidos corrigidos, como pode ser observado na equação 3 (44.1.04-C da AOAC, 2000; Gratão et al., 2004). O grau de inversão para o xarope invertido utilizado na irradiação com ${ }^{60} \mathrm{Co}$ foi de $69 \%$ e na irradiação com feixe de elétrons de $65 \%$. 


$$
\text { Brix }_{\text {corrigido }}=\text { Brix } x_{\text {temperatura }}+x_{\text {inversão }} \text { Brix } x_{\text {temperatura }} F \text { Equaçãa } 3
$$

Na qual:

Brix $_{\text {temperatura }}=$ valor de ${ }^{0} \mathrm{Brix}$ corrigido para a temperatura de referência de $20^{\circ} \mathrm{C}$.

$X_{\text {inversão }}=$ porcentagem de inversão do açúcar liquido.

$\mathrm{F}=0,022$.

\subsection{5 pH}

$\mathrm{O} \mathrm{pH}$ foi medido em um pHmetro digital da Quimis (modelo Q400M), acoplado com sensor de temperatura.

\subsubsection{Umidade}

As medidas de umidades foram efetuadas em um titulador Karl Fischer Metller Toledo (modelo Grafix 50).

\subsubsection{Determinação dos açúcares}

- Preparo das soluções de fehling

As soluções de Fehling recebem o nome de A e B. A solução A foi preparada pesando $34,639 \mathrm{~g}$ de sulfato de cobre e diluindo para $1000 \mathrm{~mL}$, com água destilada. A solução $\mathrm{B}$, foi preparada pesando $173 \mathrm{~g}$ de tartarato de sódio e potássio e dissolvendo em $250 \mathrm{~mL}$ de água destilada, adicionou-se $250 \mathrm{~mL}$ de solução de $\mathrm{NaOH}$ a $20 \%$ e completou o volume para $1000 \mathrm{~mL}$ (Instituto Adolfo Lutz, 2005).

A função da solução B é manter o hidrato cúprico em solução, impedindo a formação de hidróxido cúprico insolúvel, que teria lugar se existisse cobre livre na solução alcalina (Demiate et al., 2002; Instituto Adolfo Lutz, 2005).

- Padronização das soluções de fehling

A padronização das soluções A e B foi realizada com glicose. Pesou-se $1 \mathrm{~g}$ de glicose e diluiu-se em $100 \mathrm{~mL}$ de água destilada. Este material foi transferido para a bureta. Em um balão de titulação adicionou $10 \mathrm{~mL}$ de cada uma das soluções, A e B, e 40 
$\mathrm{mL}$ de água destilada. Titulou-se mantendo a fervura e agitação da solução até tornar-se incolor (Instituto Adolfo Lutz, 2005).

$\mathrm{O}$ cálculo do fator $\mathrm{f}$ das soluções é realizado pela equação 4 :

$$
f=V \times 0,01 \quad \text { Equação } 4
$$

Na qual:

$\mathrm{V}=$ volume de glicose gasto em $\mathrm{mL}$.

\section{- Determinação dos açúcares redutores}

A determinação de açúcares redutores (glicose + frutose) foi realizada seguindo o método de Fehling, em triplicata (Instituto Adolfo Lutz, 2005).

Em um balão de fundo chato adicionou $5 \mathrm{~mL}$ da solução A, $5 \mathrm{~mL}$ da solução $B$ e $40 \mathrm{~mL}$ de água destilada, a mistura tem a coloração azul. A titulação foi realizada sob fervura desta mistura. $\mathrm{O}$ agente titulante foi preparado pesando aproximadamente $2 \mathrm{~g}$ de açúcar invertido e diluindo com $250 \mathrm{ml}$ de água destilada. A titulação foi encerrada quando a coloração azul desapareceu e restou no fundo do balão um precipitado vermelho (óxido cuproso).

O cálculo da concentração de açúcares redutores na amostra é feito pela equação 5 (Instituto Adolfo Lutz, 2005).

$$
\operatorname{Açúcares~redutores~}(\mathrm{g} / 100 \mathrm{~g})=\frac{250 \times \frac{f}{2} \times 100}{V \times m} \text { Equação } 5
$$

Na qual:

$\mathrm{V}=$ volume gasto na titulação $\mathrm{em} \mathrm{mL}$.

$\mathrm{f}=$ glicose em gramas $(\mathrm{g})$ correspondente a $10 \mathrm{~mL}$ das soluções de Fehling (fator de padronização).

$\mathrm{m}=$ massa da amostra em gramas $(\mathrm{g})$.

- Determinação de açúcares totais

A determinação de açúcares totais foi realizada pelo método de Fehling, seguindo a metodologia descrita pelo Instituto Adolfo Lutz, 2005. Pesou-se $2 \mathrm{~g}$ de açúcar invertido em um balão de fundo chato com tampa. Neste balão, adicionou-se $1 \mathrm{~mL}$ de ácido clorídrico e $40 \mathrm{~mL}$ de água destilada e deixou em banho-maria à $98{ }^{\circ} \mathrm{C}$ por 45 
minutos, para realizar a quebra da molécula de sacarose. A reação de quebra da sacarose parou após adição de carbonato de sódio até o pH atingir o valor de 7,0 (Instituto Adolfo Lutz, 2005).

Esta mistura foi transferida, quantitativamente, para balão volumétrico adicionando água destilada até completar o volume de $100 \mathrm{~mL}$, constituindo o agente titulante. Em um balão de fundo chato adicionou $5 \mathrm{~mL}$ da solução $\mathrm{A}, 5 \mathrm{~mL}$ da solução $\mathrm{B}$ e $40 \mathrm{~mL}$ de água destilada. E a titulação foi realizada sob fervura desta mistura. A titulação foi encerrada quando a coloração azul desapareceu e restou no fundo do balão um precipitado vermelho (óxido cuproso) (Instituto Adolfo Lutz, 2005).

O cálculo dos açúcares totais é realizado pela equação 6 (Instituto Adolfo Lutz, 2005).

$$
\text { açúcares totais }(\mathrm{g} / 100 \mathrm{~g})=\frac{100 \times \mathrm{f} / 2 \times 100}{V \times m} \text { Equação } 6
$$

Na qual:

$\mathrm{V}=$ volume gasto na titulação em $\mathrm{mL}$.

$\mathrm{f}=$ glicose em gramas $(\mathrm{g})$ correspondente a $10 \mathrm{~mL}$ das soluções de Fehling. $\mathrm{m}=$ massa da amostra em gramas $(\mathrm{g})$.

\section{- Determinação da sacarose}

O teor de sacarose da amostra foi calculado pela diferença do teor de açúcares totais e açúcares redutores multiplicado pelo fator de 0,95 (Instituto Adolfo Lutz, 2005).

\subsubsection{Cor}

A análise da cor seguiu o método ICUMSA (Instituto Adolfo Lutz, 2005), com modificações. Transferiu-se a amostra diretamente para uma cubeta de quartzo. A referência adotada foi a água destilada. As leituras de absorbância foram realizadas no comprimento de onda de $420 \mathrm{~nm}$, em triplicata. O cálculo foi efetuado pela equação 7 . 


$$
\operatorname{Cor}(U I)=\frac{1000 \times A}{b \times c} \quad \text { Equação } 7
$$

Na qual:

$A=$ absorbância da solução medida a $420 \mathrm{~nm}$.

$\mathrm{b}=$ espessura da cubeta em $\mathrm{cm}$.

$\mathrm{c}=$ concentração da solução $\mathrm{em} \mathrm{g} / \mathrm{mL}$.

\subsubsection{Hidroximetilfurfural}

As soluções de Carrez I, II e bissulfito de sódio foram preparadas no dia da análise.

A solução de Carrez I foi preparada dissolvendo $15 \mathrm{~g}$ de ferrocianeto de potássio em $100 \mathrm{~mL}$ de água destilada e a solução de Carrez II pela dissolução de $30 \mathrm{~g}$ de acetato de zinco em $100 \mathrm{~mL}$ de água destilada. A solução de bissulfito de sódio foi preparada pesando-se $0,2 \mathrm{~g}$ deste reagente e diluindo em $100 \mathrm{~mL}$ de água destilada.

Para a análise de hidroximetilfurfural (HMF) da amostra, pesou-se $5 \mathrm{~g}$ de açúcar invertido e transferiu-se com $25 \mathrm{~mL}$ de água destilada para um balão volumétrico de $50 \mathrm{~mL}$. Adicionou-se $0,5 \mathrm{~mL}$ da solução de Carrez I e agitou, procedeu-se da mesma forma para a solução de Carrez II. Completou-se o volume do balão com água destilada. Filtrouse, descartando os primeiros $10 \mathrm{~mL}$ do filtrado. Pipetou-se $5 \mathrm{~mL}$ deste filtrado para cada um dos dois tubos de ensaio. Adicionou-se $5 \mathrm{~mL}$ de água em um dos tubos (amostra) e 5 $\mathrm{mL}$ de bissulfito de sódio à $0,2 \%$ no outro (referência). Os tubos foram mantidos em banho ultrassônico por 3 minutos e a absorbância foi medida à $284 \mathrm{~nm}$ e $336 \mathrm{~nm}$ em cubetas de quartzo. $\mathrm{O}$ teor de HMF foi realizado pelo cálculo apresentado na equação 8 (Instituto Adolfo Lutz, 2005).

$$
\operatorname{HMF}(\mathrm{mg} / \mathrm{Kg})=\frac{\left(A_{284}-A_{336}\right) \times 149,7 \times 5}{m} \text { Equaçăo } 8
$$


Na qual:

$\mathrm{A}_{284}=$ leitura da absorbância à $284 \mathrm{~nm}$.

$\mathrm{A}_{336}=$ leitura da absorbância à $336 \mathrm{~nm}$.

$\mathrm{m}=$ massa da amostra em gramas $(\mathrm{g})$.

$5=$ massa nominal da amostra em gramas.

$149,7=(126 / 16830) \times(1000 / 10) \times(1000 / 5)$.

126=peso molecular do HMF.

$16830=$ absortividade molar do HMF a $2820 \mathrm{~nm}$.

$1000=$ conversão de $\mathrm{g}$ para $\mathrm{mg}$.

$10=$ diluição de $5 \mathrm{~g}$ para $50 \mathrm{~mL}$.

$1000=$ conversão de $\mathrm{g}$ para $\mathrm{kg}$.

\subsubsection{Varredura na região do ultravioleta}

A varredura no ultravioleta foi realizada entre os comprimentos de onda de 190 nm e $350 \mathrm{~nm}$, seguindo metodologia descrita por Liggett et al., 1959, com modificações. Pesou-se 2,5 g dẹ açúcar invertido e diluiu-se com água destilada em balão de $25 \mathrm{~mL}$. Transferiu-se uma alíquota da amostra para uma cubeta de quartzo. A referência adotada foi água destilada. A varredura foi realizada em espectrofotômetro.

\subsubsection{Viscosidade}

O estudo reológico foi realizado em um viscosímetro Brookfield modelo LVDVIII, com adaptador para pequenas amostras com capacidade de $8 \mathrm{~mL}$ e spindle SC4-34. O banho termostático Neslab operou com água destilada à temperatura de $24,6 \pm 0,1{ }^{\circ} \mathrm{C}$. As amostras permaneceram no copo do viscosímetro por 10 minutos antes de efetuar as medidas, até atingir o equilibrio térmico com o banho (Yu et al., 2004).

O comportamento do fluido foi estudado em três dias diferentes, para as amostras irradiadas com o cobalto-60, utilizando as mesmas amostras. Nos dois primeiros dias de ensaio, a velocidade de rotação do spindle foi programada para variar entre 2 e 20 rpm, com acréscimo de $1 \mathrm{rpm}$ entre as leituras. No terceiro dia, a velocidade foi alterada para a faixa entre 5 e $20 \mathrm{rpm}$, com acréscimo de $2,5 \mathrm{rpm}$ entre as leituras. $O$ torque permaneceu entre 10 e $90 \%$. A medida de viscosidade foi realizada 8 vezes em cada uma das amostras, a rotação do spindle foi mantida em $20 \mathrm{rpm}$. 
O mesmo procedimento foi seguido para as amostras irradiadas no acelerador de elétrons, com exceção que as análises foram efetuadas em apenas um dia.

\subsection{Análises Microbiológicas}

As análises microbiológicas foram realizadas em duplicata para contagem total de bolores e leveduras. $O$ cronograma de análise seguiu-se realizando uma análise a cada mês logo após a irradiação: agosto/05, setembro/05, dezembro/05 e janeiro/06, quando se encerrou o prazo de validade deste lote do açúcar invertido (data de fabricação: 18/07/2005). A partir de então, as amostras foram analisadas duas vezes ao mês, com intervalo de 15 dias entre as análises, até o mês de abril de 2006. Durante todo o período de análise, as amostras foram retiradas do mesmo frasco. Ao todo foram 6 frascos, um contendo a amostra controle e os demais, as amostras irradiadas, em fonte de cobalto-60, com doses de 5, 10,20,30 e $50 \mathrm{kGy}$. As amostras foram armazenadas na ausência de luz e a temperatura ambiente.

\subsubsection{Reagentes}

Potato dextrose agar (PDA) da Merck, água peptonada da Vetec, membrana 0,2 $\mu \mathrm{m}$ da Scleider \& Schuell, ácido tatárico da Merck.

\subsubsection{Métodos}

- Preparo do meio de cultura

$\mathrm{O}$ meio de cultura foi preparado pesando-se $39 \mathrm{~g}$ de agar batata dextrose e diluindo-se para $1 \mathrm{~L}$. Deixou-se em repouso por 15 minutos, em seguida aqueceu-se em chama de bico de bunsen até ficar transparente. A este meio foi adicionado $10 \mathrm{~mL}$ de ácido tartárico. $\mathrm{O}$ ácido tartárico foi preparado à $10 \%$, diluindo-se $10 \mathrm{~mL}$ de ácido em $100 \mathrm{~mL}$ de água destilada e filtrando-se em membrana de 0,2 $\mu \mathrm{m}$ (Silva et al., 2001). 


\section{- Preparo do diluente (água peptonada)}

Pesou-se $1 \mathrm{~g}$ de peptona de carne bacteriológica e dilui para $1000 \mathrm{~mL}$. Foram preparados tubos contendo $9 \mathrm{~mL}$ deste diluente que foram para autoclave a fim de esterilizar (Silva et al., 2001).

\section{- Preparo das placas}

O meio de cultura foi preparado colocando nas placas de petri de 15 a $20 \mathrm{~mL}$ de ágar batata dextrose acidificado (PDA acidificado). Este meio ficou em câmara de fluxo laminar por aproximadamente 30 minutos para secagem (Silva et al., 2001).

Pesou-se $25 \mathrm{~g}$ de açúcar líquido invertido e diluiu-se em $225 \mathrm{~mL}$ de água peptonada (diluição 1:10 ou $10^{-1}$ ). A partir desta diluição, inoculou-se três placas com 0,3 $\mathrm{mL}$ (em duplicata) e uma placa com 0,1 mL (Silva et al., 2001).

Pipetou-se $1 \mathrm{~mL}$ da diluição $10^{-1}$ para tubo de ensaio contendo $9 \mathrm{~mL}$ de água peptonada (diluição 1:100 ou $10^{-2}$ ). E, finalmente, da diluição $10^{-2}$ pipetou-se $1 \mathrm{ml}$ para tubo de ensaio com $9 \mathrm{~mL}$ de água peptonada para preparar a diluição $1: 1000$ ou $10^{-3}$. A partir das diluições $10^{-2}$ e $10^{-3}$, inoculou-se as placas com $0,1 \mathrm{~mL}$, em duplicata (Silva et al., 2001).

Para a contagem total de bolores e leveduras, as placas permaneceram incubadas por 3 dias à $25{ }^{\circ} \mathrm{C}$ e efetuou-se a leitura; após 5 dias de incubação uma nova leitura foi realizada (Silva et al., 2001).

A quantidade de açúcar invertido era limitada, por esta razão, as próximas análises partiram de $1 \mathrm{~g}$ de açúcar que foi diluído em $9 \mathrm{~mL}$ de água peptonada, para realizar a diluição $10^{-1}$, desta foi realizada a diluição $10^{-2}$. Destas diluições foram retiradas $0,1 \mathrm{~mL}$, que foram inoculadas nas placas de PDA.

\subsection{Análise sensorial}

Realizou-se o teste triangular para determinar se existia diferença perceptivel no sabor entre as amostras controle e irradiadas a $5 \mathrm{kGy}$, com radiação gama ou feixe de elétrons. Os testes para cada tipo de radiação foram realizados em dias diferentes no Laboratório de Alimentos do CTR/IPEN.

Foi apresentado a cada provador, conforme mostrado na FIG. 15, três amostras de açúcar líquido invertido codificadas com três dígitos e instruído que duas eram idênticas e uma diferente. As amostras foram apresentadas em igual número de vezes, casualizada e 
balanceada de acordo com o seguinte delineamento: $\mathrm{ABA}, \mathrm{BAB}, \mathrm{AAB}, \mathrm{BBA}, \mathrm{ABB} \mathrm{E}$ BAA. A amostra irradiada recebeu o código de A e amostra controle de $\mathrm{B}$, este delineamento foi repetido 5 vezes para completar 30 julgadores em cada uma das irradiações estudadas (Associação Brasileira de Normas Técnicas, 1993; Ferreira et al., 2000).

Solicitou-se aos provadores que provassem o açúcar líquido da esquerda para a direita, entre as amostras era permitido beber água e/ou comer uma bolacha do tipo: cream cracker. $\mathrm{Na}$ ficha que foi entregue, o julgador deveria assinalar a amostra que ele considerou com sabor diferente. A ficha está apresentada na FIG. 16 (Associação Brasileira de Normas Técnicas, 1993; Ferreira et al., 2000).

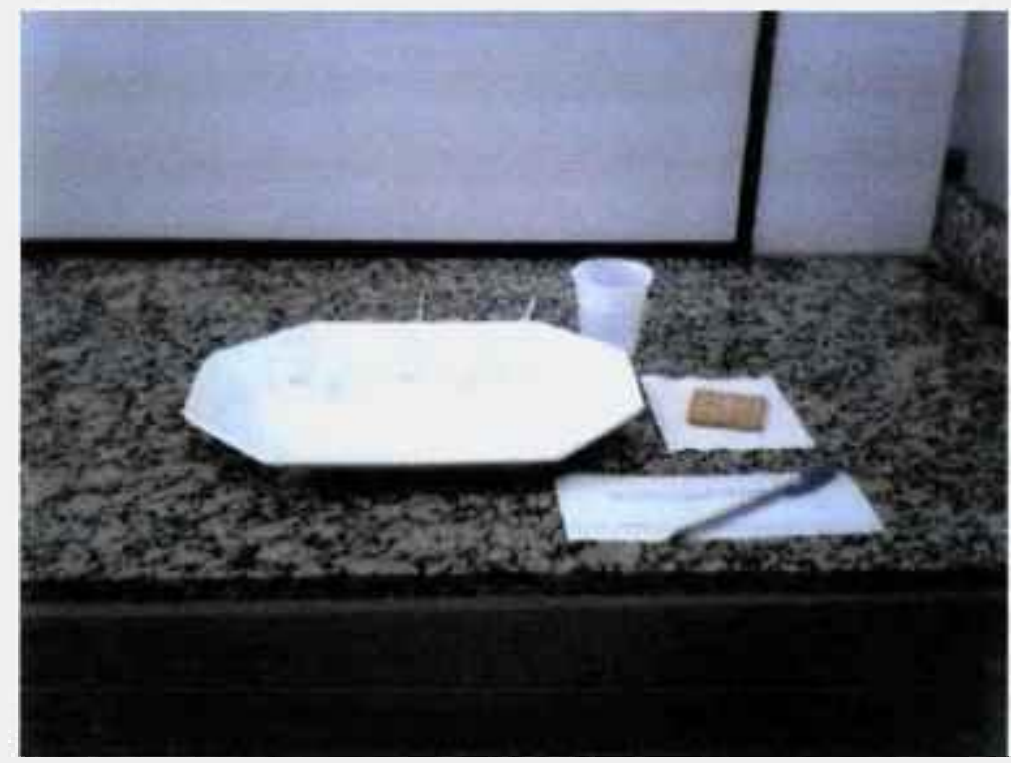

FIGURA 15 - Apresentação das amostras para o teste triangular (Ferreira et al, 2000).

Nome: Data:

Você está recebendo 3 amostras de açúcar líquido codificadas. Duas amostras são iguais e uma é diferente. Por favor, avalie o sabor das amostras da esquerda para a direita. Circule a amostra diferente

Comentários

$201 \quad 542 \quad 921$

FIGURA 16 - Modelo da ficha de avaliação apresentada aos provadores (Ferreira et al., 2000). 
A interpretação dos resultados foi baseada no número total de julgamento versus o número de julgamentos corretos. Se o número de julgamentos corretos for superior ou igual ao encontrado na tabela apresentada em O'Mahony, 1986 indica que existiu diferença significativa entre as amostras ao nível de $5 \%$.

\subsection{Tratamento dos dados}

A análise de variância (ANOVA) e os testes para comparação entre as médias (Tukey, LSD, Scheffé) foram utilizados com nível de significância de 5\%. As análises foram realizadas usando-se o programa Statistica (Statistica 5.1, StatSoft, 1998). 


\section{RESULTADOS E DISCUSSÃO}

\subsection{Propriedades físico-químicas}

\subsubsection{Densidade}

Na TAB. 10 estão apresentados os valores médios de densidade para o açúcar líquido invertido, irradiado em acelerador de elétrons e em fonte de cobalto-60.

TABELA 10 - Valores médios de densidade para as amostras de açúcar líquido: controle e irradiadas em acelerador de elétrons e em fonte de cobalto-60.

\begin{tabular}{c|c|c}
\hline \multirow{2}{*}{ Dose (kGy) } & \multicolumn{2}{|c}{ Densidade $(\mathrm{g} / \mathrm{mL})^{*}$} \\
\cline { 2 - 3 } & Acelerador de elétrons & Fonte $^{60}$ Co \\
\hline Controle & $1,407252 \pm 0,000005^{\mathrm{a}}$ & $1,393045 \pm 0,000004^{\mathrm{a}}$ \\
\hline 5 & $1,404905 \pm 0,000008^{\mathrm{b}}$ & $1,395201 \pm 0,000004^{\mathrm{b}}$ \\
\hline 10 & $1,398198 \pm 0,000004^{\mathrm{c}}$ & $1,394029 \pm 0,000005^{\mathrm{c}}$ \\
\hline 20 & $1,404359 \pm 0,000002^{\mathrm{d}}$ & $1,394373 \pm 0,000010^{\mathrm{d}}$ \\
\hline 30 & $1,402431 \pm 0,000002^{\mathrm{e}}$ & $1,395470 \pm 0,000008^{\mathrm{e}}$ \\
\hline 50 & $1,396769 \pm 0,000002^{\mathrm{f}}$ & $1,390984 \pm 0,000005^{\mathrm{f}}$ \\
\hline
\end{tabular}

Os valores acompanhados por letras diferentes numa mesma coluna são significativamente diferentes-teste Tukey.

"Análises realizadas em triplicata.

Os valores de densidade entre as amostras controle e irradiadas nos dois tipos de irradiação utilizadas variaram entre 1,39 e $1,41 \mathrm{~g} / \mathrm{mL}$. Na literatura, encontra-se os valores de 1,39 e 1,40 $\mathrm{g} / \mathrm{mL}$ para a densidade deste ingrediente (Davis \& Prince, 1955; Rodrigues et al., 2000). Na TAB. 10, os valores de densidade estão apresentados com sete algarismos significativos para indicar que a diferença estatística ao nível de $95 \%$ entre as médias, indicada através da análise de variância (ANOVA-Apêndice). A diferença estatística se deve ao pequeno desvio padrão entre as medidas. Como mostrado nas FIGS.17 e 18 . 
A alteração no valor da densidade das amostras controle e irradiadas poderia ocorrer devido a uma mudança na massa ou no volume ocupado pela solução. A irradiação não altera a massa total dos componentes sólidos da solução, uma vez que a irradiação pode provocar apenas a quebra ou polimerização das moléculas já existentes. A mudança no volume seria decorrente do aumento ou diminuição no teor de água, porém, se essa mudança ocorreu foi discreta, como será observado no item 4.1 .4 , já que os valores de densidade permaneceram praticamente inalterados.

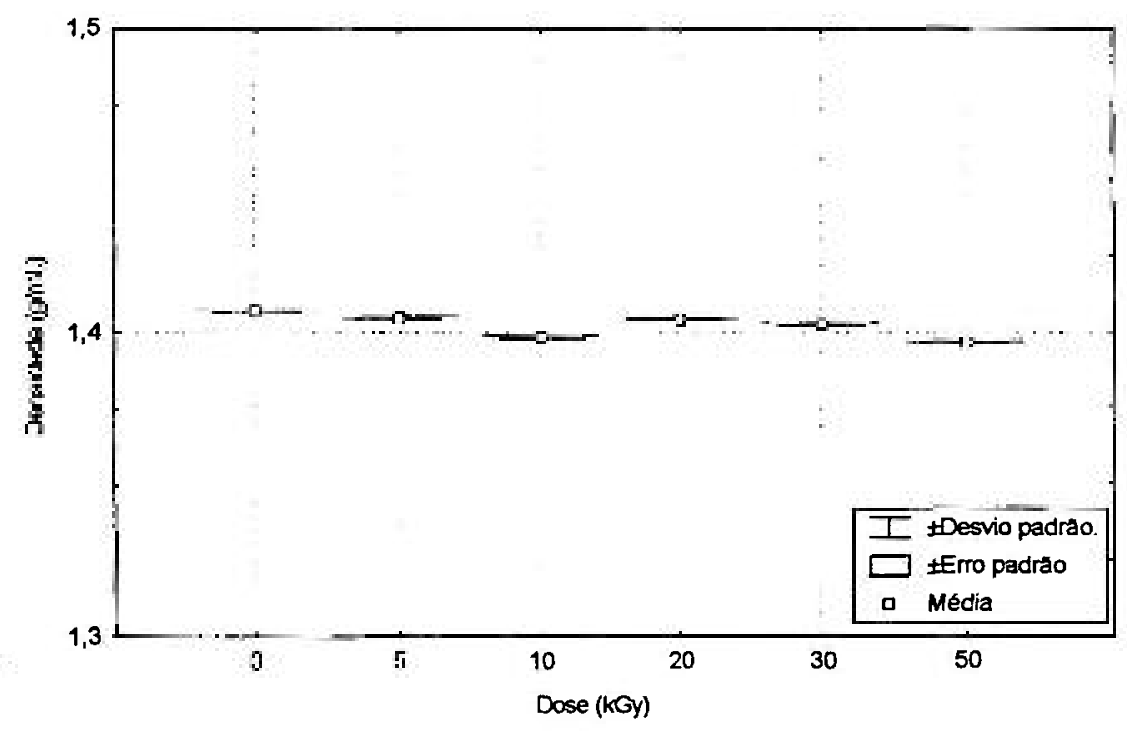

FIGURA 17 - Média das densidades em função da dose de irradiação para a amostra controle (0 kGy) e irradiadas em acelerador de elétrons à 5, 10, 20, 30 e $50 \mathrm{kGy}$.

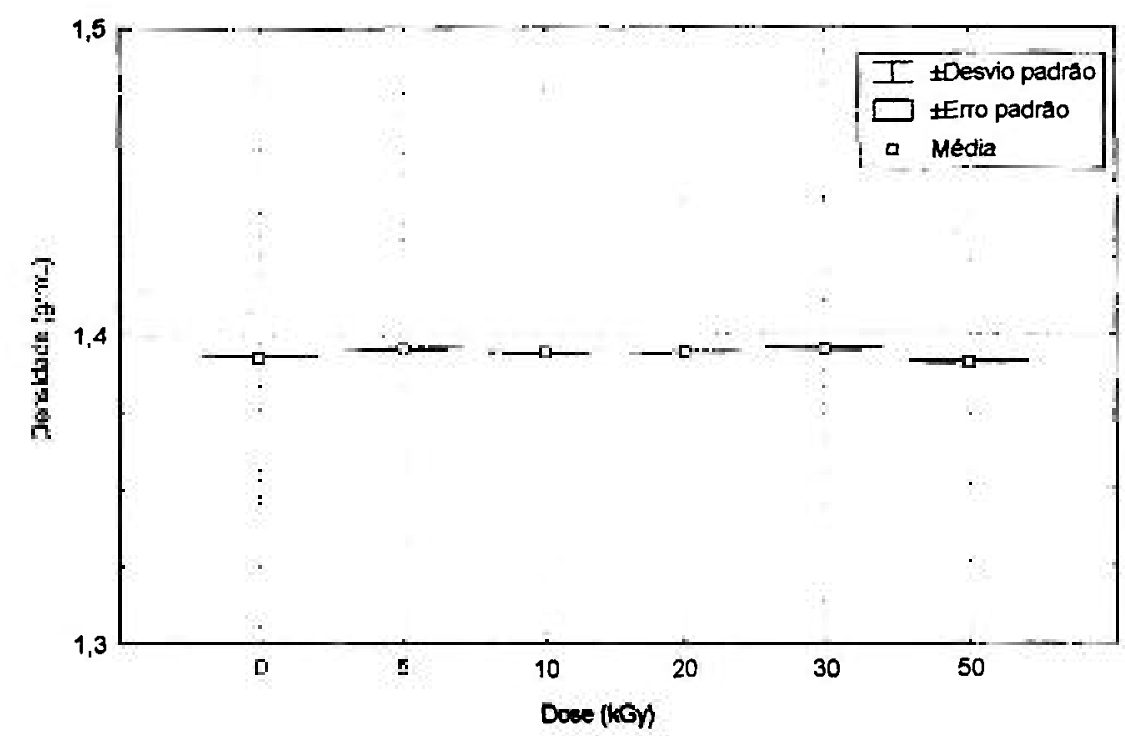

FIGURA 18 - Média das densidades em função da dose de irradiação para a amostra controle (0 kGy) e irradiadas em fonte de cobalto- 60 à 5, 10, 20, 30 e $50 \mathrm{kGy}$. 


\subsubsection{Sólidos Solúveis ( $\left.{ }^{\circ} \mathrm{Brix}\right)$}

Os teores de sólidos solúveis para as amostras controle e irradiadas com feixe de elétrons e radiação gama encontram-se resumidos na TAB. 11 . Os valores lidos de ${ }^{0} \mathrm{Brix}$ em refratômetro foram corrigidos para a temperatura padrão de $20{ }^{\circ} \mathrm{C}$ e acrescido 0,022 para cada porcentagem de açúcar invertido presente na solução (Davis \& Prince, 1955; AOAC, 2000).

TABELA 11 - Valores médios de sólidos solúveis ("Brix) para as amostras de açúcar líquido: controle e irradiadas em acelerador de elétrons e em fonte de cobalto- 60 .

\begin{tabular}{c|c|c}
\hline \multirow{2}{*}{ Dose (kGy) } & \multicolumn{2}{|c}{ Sólidos solúveis $(\%)^{*}$} \\
\cline { 2 - 3 } & $\begin{array}{c}\text { Acelerador de } \\
\text { elétrons }\end{array}$ & Fonte ${ }^{60}$ Co \\
\hline Controle & $78,74 \pm 0,19^{\mathrm{a}}$ & $78,76 \pm 0,16^{\mathrm{a}}$ \\
\hline 5 & $78,78 \pm 0,06^{\mathrm{a}}$ & $79,06 \pm 0,06^{\mathrm{b}}$ \\
\hline 10 & $78,82 \pm 0,06^{\mathrm{a}}$ & $79,09 \pm 0,12^{\mathrm{b}}$ \\
\hline 20 & $78,85 \pm 0,00^{\mathrm{a}}$ & $79,33 \pm 0,00^{\mathrm{c}}$ \\
\hline 30 & $78,95 \pm 0,00^{\mathrm{a}}$ & $79,33 \pm 0,00^{\mathrm{c}}$ \\
\hline 50 & $78,99 \pm 0,06^{\mathrm{a}}$ & $79,33 \pm 0,00^{\mathrm{c}}$ \\
\hline
\end{tabular}

Os valores acompanhados por letras diferentes numa mesma coluna são significativamente diferentes-teste Tukey.

Análises realizadas em triplicata.

A análise de variância (ANOVA) para os valores de sólidos solúveis obtido com as amostras controle e irradiadas em fonte de ${ }^{60} \mathrm{Co}$, através do teste $\mathrm{F}$, indicou que há diferença estatística entre as médias ao nível de $95 \%$ de confiança (Apêndice). A comparação entre médias (teste de Tukey) indicou que ocorreram diferenças estatísticas entre as amostras.

A FIG. 19 apresenta o perfil dos sólidos solúveis em função da dose no estudo realizado com o feixe de elétron. Notou-se um comportamento linear a partir da amostra controle até a amostra irradiada à $20 \mathrm{kGy}$. Entre a amostra de 20 e $30 \mathrm{kGy}$ ocorreu um acréscimo mais acentuado, enquanto o aumento foi discreto da amostra de 30 para a de 50 kGy.

Na FIG. 20, pode-se observar que as diferenças estatísticas ocorreram entre a amostra controle e irradiadas em fonte de cobalto-60 e entre as amostras irradiadas a diferença foi entre as amostras de 5 e $10 \mathrm{kGy}$ e as de 20,30 e $50 \mathrm{kGy}$. 
$\mathrm{O}$ valor médio de ${ }^{0} \mathrm{Brix}$ calculado para todas as amostras utilizadas no ensaio do acelerador de elétron foi de $78,9 \pm 0,1 \%$. Para o açúcar líquido invertido, o teor de sólidos solúveis situa-se entre $60-90 \%$, sendo mais comum o açúcar com valor em torno de $76,5 \%$ (Gratão et al., 2004).

O laudo da usina DaBarra forneceu o valor de ${ }^{0}$ Brix de $76,9 \%$ para a amostra controle, utilizada no ensaio com acelerador de elétrons, porém não especifica a metodologia usada para realizar esta medida. Nesta pesquisa, a leitura de ${ }^{0}$ Brix, sem efetuar correção, foi bastante próxima ao valor emitido pela empresa $(77,4 \%)$.

Em relação às amostras utilizadas no ensaio com radiação gama, o valor médio de ${ }^{0}$ Brix permaneceu ao redor de 79,2 $\pm 0,1$. O laudo emitido pela Usina Da Barra forneceu o valor de 76,7\%. Este valor está próximo ao valor obtido pelo controle nesta pesquisa que foi de $77,3 \%$, sem efetuar a correção para temperatura e a concentração de açúcar invertido.

As amostras irradiadas no acelerador de elétrons e na fonte de cobalto 60 apresentaram o teor de sólidos solúveis maior que o controle, este fato indica que as moléculas de açúcar presentes em solução ao receberem a energia proveniente da radiação podem ter sofrido quebras, gerando moléculas de menor massa molecular, como por exemplo, ácidos, aumentando a concentração de sólidos solúveis. A quebra das moléculas acentua-se com o aumento da dose (Phillips, 1961), e os dados obtidos neste trabalho mostram que o aumento da dose impactou diretamente o valor de sólidos solúveis, com exceção das amostras que receberam radiação gama nas doses de 20,30 e $50 \mathrm{kGy}$, que tiveram valores constantes de ${ }^{0}$ Brix. A formação dos ácidos pode ser observada pela redução do $\mathrm{pH}$, conforme será discutido no item 4.1.3 (Bothner-by \& Balazs, 1957; Phillips, 1961; Diehl et al., 1978). 


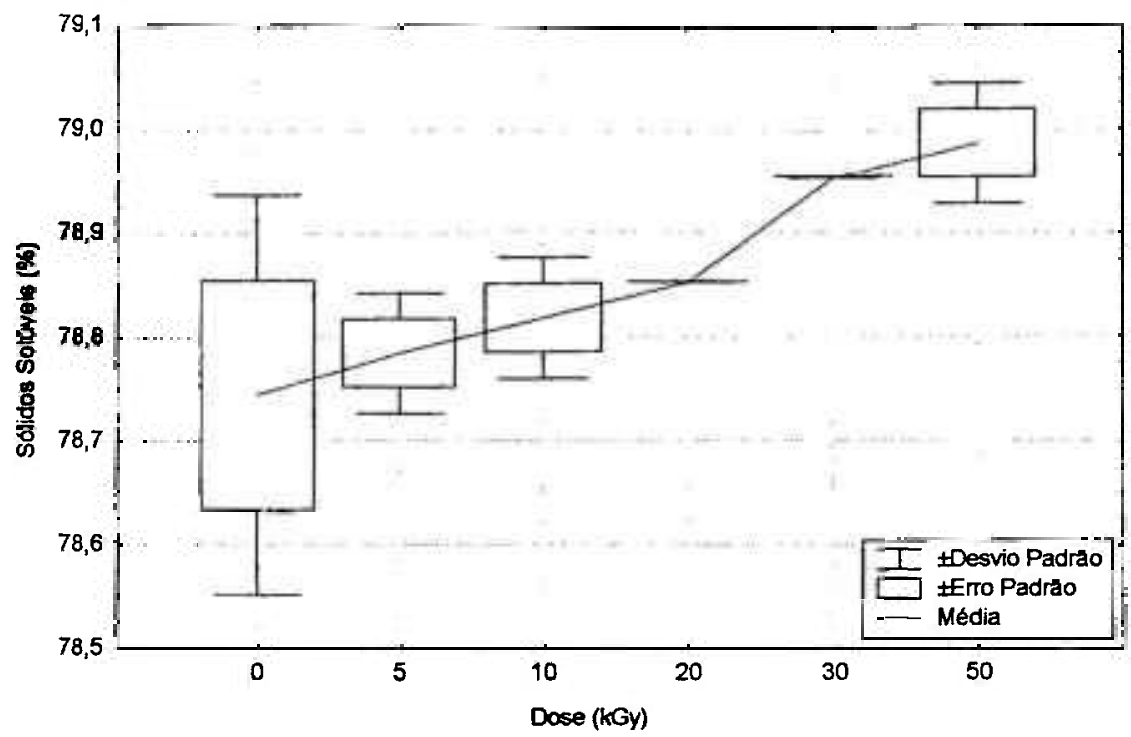

FIGURA 19 - Média do teor de sólidos solúveis em função da dose de irradiação para a amostra controle e irradiadas em acelerador de elétrons à $5,10,20,30$ e $50 \mathrm{kGy}$.

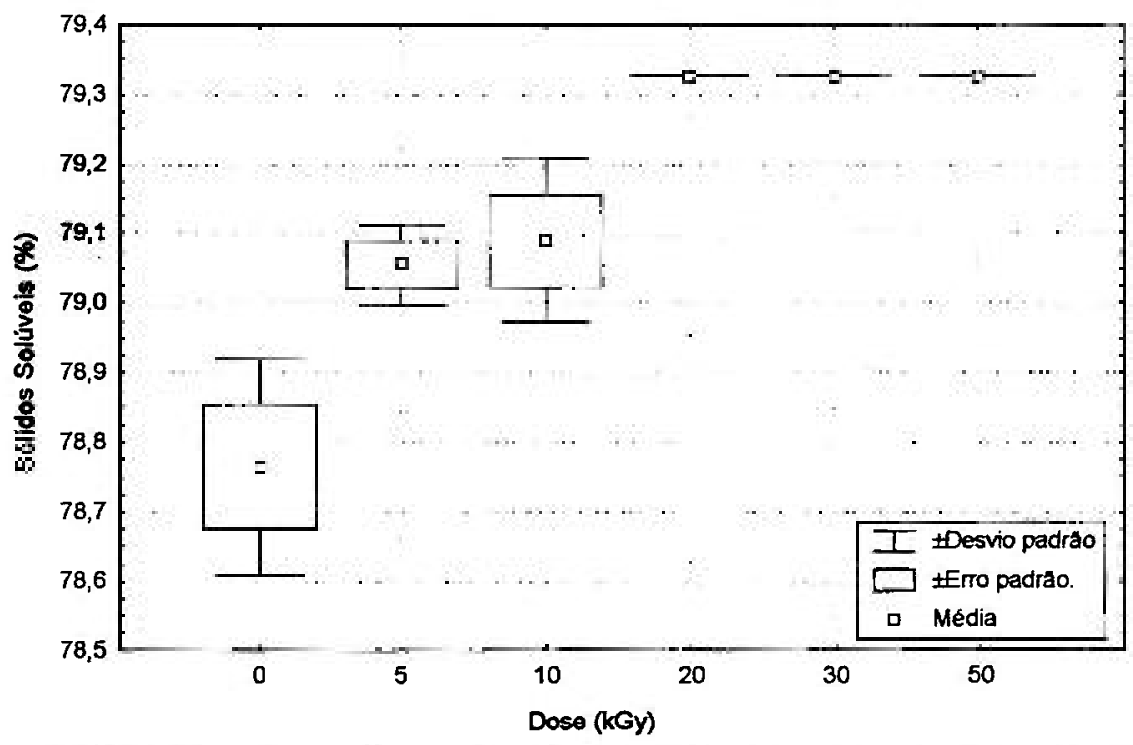

FIGURA 20 - Média do teor de sólidos solúveis em função da dose de irradiação para a amostra controle ( $0 \mathrm{kGy}$ ) e irradiadas em fonte de cobalto-60 à 5, 10, 20, 30 e $50 \mathrm{kGy}$.

\subsection{3 $\mathrm{pH}$}

Os valores de $\mathrm{pH}$ variaram ente 2,9 e 4,7, como apresentado na TAB. 12. 
TABELA 12: Valores médios de pH para as amostras de açúcar líquido: controle e irradiadas em acelerador de elétrons e em fonte de cobalto-60.

\begin{tabular}{c|c|c}
\hline \multirow{2}{*}{ Dose (kGy) } & \multicolumn{2}{|c}{$\mathrm{pH}^{*}$} \\
\cline { 2 - 3 } & $\begin{array}{c}\text { Acelerador de } \\
\text { elétrons }\end{array}$ & Fonte ${ }^{60} \mathrm{Co}$ \\
\hline Controle & $4,43 \pm 0,01^{\mathrm{a}}$ & $4,72 \pm 0,03^{\mathrm{a}}$ \\
\hline 5 & $4,12 \pm 0,01^{\mathrm{b}}$ & $4,30 \pm 0,05^{\mathrm{b}}$ \\
\hline 10 & $3,90 \pm 0,08^{\mathrm{c}}$ & $4,01 \pm 0,10^{\mathrm{c}}$ \\
\hline 20 & $3,83 \pm 0,10^{\mathrm{c}}$ & $3,72 \pm 0,06^{\mathrm{d}}$ \\
\hline 30 & $3,28 \pm 0,03^{\mathrm{d}}$ & $3,49 \pm 0,09^{\mathrm{e}}$ \\
\hline 50 & $2,88 \pm 0,01^{\mathrm{e}}$ & $3,27 \pm 0,03^{\mathrm{f}}$ \\
\hline
\end{tabular}

Os valores acompanhađos por letras diferentes numa mesma coluna são significativamente diferentes-teste Tukey.

"Análises realizadas em triplicata.

A análise de variância (ANOVA) indicou que há diferença significativa entre as médias de $\mathrm{pH}$ ao nível de $95 \%$ de confiança (Apêndice).

Em ambas as técnicas de irradiação utilizadas, os valores de $\mathrm{pH}$ diminuíram à medida que a dose de irradiação aumentou. A radiação ao interagir com as moléculas de sacarose, glicose e frutose fragmentam essas moléculas com a formação de ácidos. $\mathrm{O}$ aumento da dose de radiação aplicada proporciona maior formação de radicais, que irão interagir com as moléculas de açúcar, formando maior quantidade de compostos com caráter ácido (Phillips, 1961; Oh et al., 2006). Os ácidos formados na irradiação por cobalto-60 são semelhantes aos obtidos na irradiação pelo acelerador de elétrons e já comentados previamente (Desrosier \& Rosenstock, 1960; Phillips,1961; Diehl et al., 1978; Josephson \& Peterson, 1983; Deeble et al., 1991; Gray \& Mower, 1991; International Consultive Group on Food Irradiation, 1992; Vieira \& Del Mastro, 2002; Waisikiewicz et al., 2005). Os ácidos formados podem ter contribuído para o aumento da concentração de sólidos solúveis. Através do gráfico de sólidos solúveis em função do $\mathrm{pH}$ obteve-se um alto valor de correlação: $\mathrm{R}^{2}=0,9855$, para as amostras usadas no ensaio com o acelerador de elétrons. No estudo com a radiação gama, o valor também foi significativo: $\mathbf{R}^{2}=0,9013$. Estes dois gráficos estão mostrados nas FIGS. 21 e 22, respectivamente.

A literatura é bastante escassa em trabalhos que descrevam o efeito da radiação em amostras de açúcar líquido invertido. Marignetti \& Mantovani, 1979/80 pesquisando o efeito da radiação ultravioleta nas propriedades do açúcar invertido observaram a redução de $\mathrm{pH}$. Este fato está condizente com os resultados apresentados neste trabalho. 


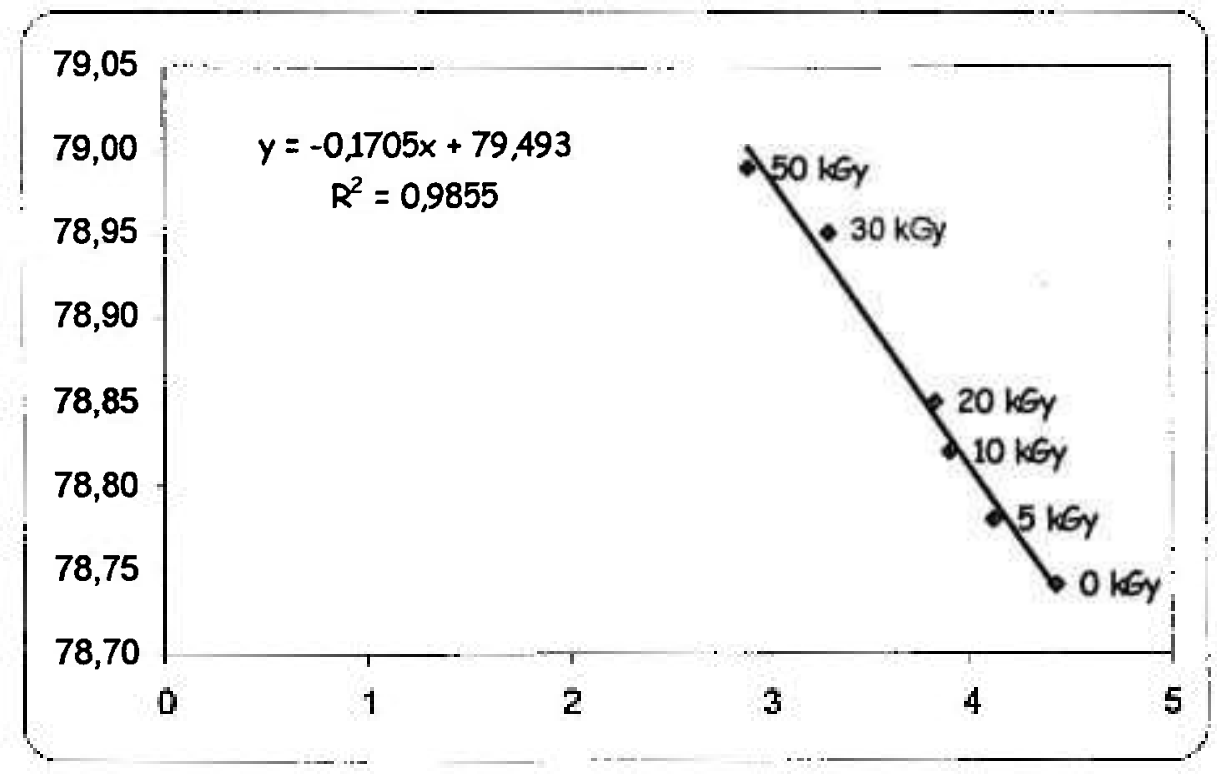

FIGURA 21 - Curva do teor de sólidos solúveis ("Brix) em função do pH para a amostra controle e irradiadas em acelerador de elétrons.

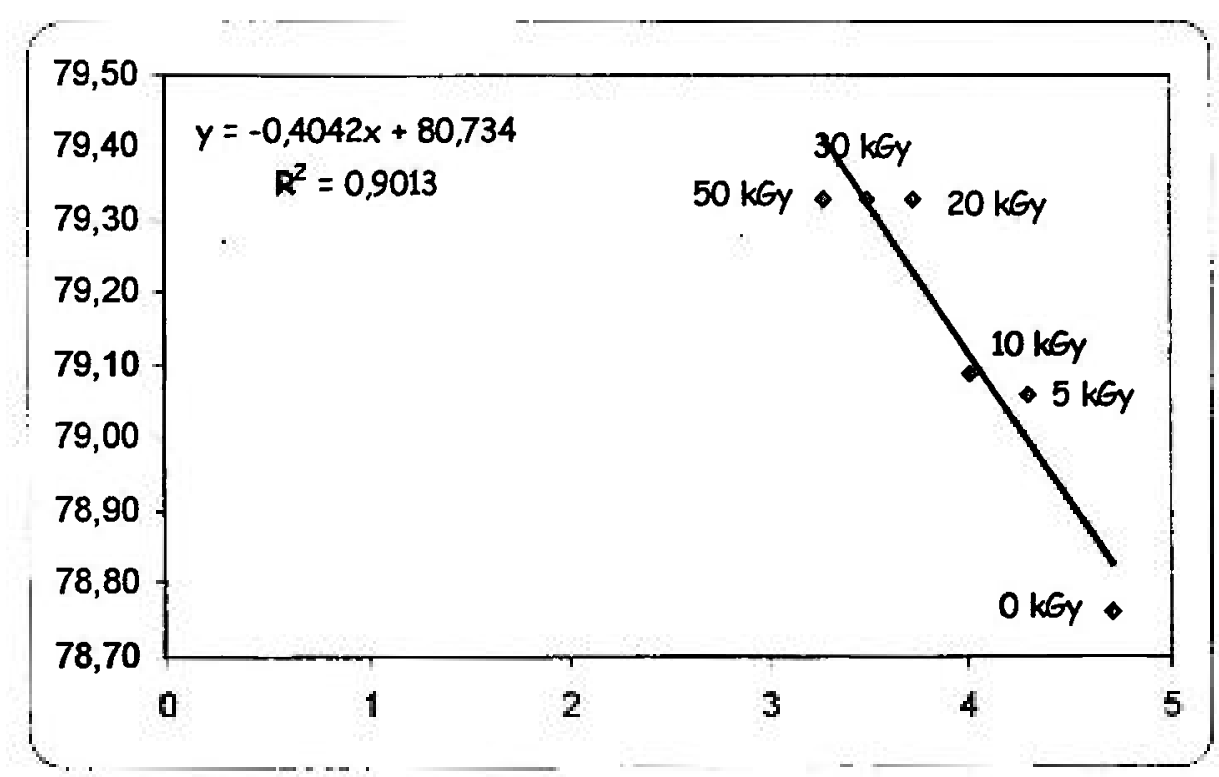

FIGURA 22 - Curva do teor de sólidos solúveis ("Brix) em função do pH para a amostra controle e irradiadas com radiação gama.

\subsubsection{Umidade}

Os valores de umidade obtidos, pelo método de Karl Fischer, para as amostras controle e irradiadas em acelerador de elétrons e com fonte de ${ }^{60} \mathrm{Co}$, estão resumidos na TAB. 13. Os teores de umidade variaram entre $20,5 \%$ e $21,6 \%$. 
TABELA 13 - Valores médios de umidade para as amostras de açúcar líquido: controle e irradiadas em acelerador de elétrons e em fonte de cobalto-60. Método Karl Fischer.

\begin{tabular}{c|c|c}
\hline \multirow{2}{*}{ Dose (kGy) } & \multicolumn{2}{|c|}{ Umidade Karl Fischer $(\%)^{*}$} \\
\cline { 2 - 3 } & $\begin{array}{c}\text { Acelerador de } \\
\text { elétrons }\end{array}$ & Fonte $^{60} \mathrm{Co}$ \\
\hline Controle & $21,55 \pm 0,44^{\mathrm{a}}$ & $20,71 \pm 0,10^{\mathrm{a}}$ \\
\hline 5 & $21,57 \pm 0,32^{\mathrm{a}}$ & $20,57 \pm 0,21^{\mathrm{a}}$ \\
\hline 10 & $21,38 \pm 0,25^{\mathrm{a}}$ & $20,49 \pm 0,15^{\mathrm{a}}$ \\
\hline 20 & $21,19 \pm 0,15^{\mathrm{a}}$ & $21,46 \pm 0,17^{\mathrm{b}}$ \\
\hline 30 & $21,20 \pm 0,18^{\mathrm{a}}$ & $21,45 \pm 0,45^{\mathrm{b}}$ \\
\hline 50 & $21,24 \pm 0,13^{\mathrm{a}}$ & $21,37 \pm 0,34^{\mathrm{b}}$ \\
\hline
\end{tabular}

Os valores acompanhados por letras diferentes numa mesma coluna são significativamente diferentes-teste LSD.

"Análises realizadas em triplicata.

Em relação aos dados obtidos no acelerador de elétrons, a análise de variância (ANOVA-Apêndice) mostrou, através da razão $\mathrm{F}$, que não ocorreu diferença estatística entre as médias $(p<0,05)$, nas amostras controle e que passaram pelo feixe de elétrons. Desta forma, as alterações nos valores de umidade não são reflexo das diferentes doses de irradiação aplicadas no açúcar.

As amostras, com exceção da que recebeu a dose de $5 \mathrm{kGy}$, apresentaram redução discreta no valor da umidade em relação ao controle. Esta redução pode ter ocorrido durante o processo de irradiação no acelerador de elétrons, uma vez que a amostra sofre leve aquecimento decorrente da alta taxa de dose, que pode ter sido responsável pela evaporação da água e redução discreta do teor de umidade das amostras. Outro fato que pode ter contribuído para a redução da umidade é a reação de hidrólise que a molécula de sacarose sofre, tanto pela irradiação recebida como pela presença de ácidos em solução. Esta reação ocorre pela adição de uma molécula de água.

No ensaio realizado na fonte de cobalto-60, as amostras controle, 5 e $10 \mathrm{kGy}$ apresentaram valores de umidade estatisticamente diferentes das amostras irradiadas com doses de 20,30 e $50 \mathrm{kGy}(\mathrm{p}<0,05)$. As amostras que receberam as maiores doses de irradiação apresentaram aumento de umidade. A frutose é um açúcar higroscópico, que está presente no açúcar invertido, além de poder ser formado durantè a irradiação, a sua presença pode ter contribuído para o aumento da umidade das amostras em relação ao controle (Dittmar, 1935). Ao contrário do que acontece no acelerador de elétrons, na fonte de cobalto-60 não ocorreu aquecimento da amostra.

Os teores de umidade também foram determinados através do método de refratometria (Instituto Adolfo Lutz, 2005). A determinação da umidade através do método por refratometria é um método indireto, utiliza-se uma tabela contendo os índices de 
refração e os respectivos valores de umidade. A sua vantagem é a simplicidade da técnica, não requer reagentes especiais e nem equipamentos diferenciados para a determinação, apenas um refratômetro. A TAB. 14 apresenta os dados obtidos com a construção da curva do indice de refração em função da umidade, obtidos do Manual de Método Físico-Químicos para Análise de Alimentos do Instituto Adolfo Lutz (Instituto Adolfo Lutz, 2005). Através da leitura do índice de refração no refratômetro das amostras foi possível obter a umidade, pela equação da reta.

TABELA 14 - Equação da reta obtida através do gráfico: umidade versus índice de refração

\begin{tabular}{c|c|c|c}
\hline $\begin{array}{c}\text { Faixa Umidade } \\
(\%)\end{array}$ & $\begin{array}{c}\text { Faixa índice de } \\
\text { refração a 20 } \mathrm{C}\end{array}$ & Equação da reta & $\begin{array}{c}\text { Coeficiente de } \\
\text { correlação }\end{array}$ \\
\hline $13-25$ & $1,4740-1,5044$ & $\mathrm{Y}=-396,14 \mathrm{X}+608,87$ & 0,9999 \\
\hline
\end{tabular}

Fonte: Instituto Adolfo Lutz, 2005.

$\mathrm{Na}$ TAB. 15, estão apresentados os valores de umidade para as amostras que sofreram radiação por feixe de elétrons e gama, utilizando o método de refratometria. Os valores de umidade foram calculados através da equação da reta apresentada na TAB. 14.

TABELA 15 - Valores médios de umidade para as amostras de açúcar líquido: controle e irradiadas em acelerador de elétrons e em fonte de cobalto-60. Método Refratometria.

\begin{tabular}{|c|c|c|}
\hline \multirow[b]{2}{*}{ Dose (kGy) } & \multicolumn{2}{|c|}{ Umidade Refratometria $(\%)^{*}$} \\
\hline & $\begin{array}{l}\text { Acelerador de } \\
\text { elétrons }\end{array}$ & Fonte ${ }^{60} \mathrm{Co}$ \\
\hline Controle & $20,99 \pm 0,15^{a}$ & $20,96 \pm 0,11^{a}$ \\
\hline 5 & $20,92 \pm 0,00^{\mathrm{a}}$ & $20,71 \pm 0,02^{b}$ \\
\hline 10 & $20,90 \pm 0,05^{a}$ & $20,63 \pm 0,09^{\mathrm{ct}}$ \\
\hline 20 & $20,72 \pm 0,00^{\mathbf{b}}$ & $20,53 \pm 0,00^{c}$ \\
\hline 30 & $20,72 \pm 0,00^{b}$ & $20,53 \pm 0,00^{\mathrm{c}}$ \\
\hline 50 & $20,72 \pm 0,00^{b}$ & $20,53 \pm 0,00^{\mathrm{c}}$ \\
\hline
\end{tabular}

Os valores acompanhados por letras diferentes numa mesma coluna são significativamente diferentes-teste Tukey.

"Análises realizadas em triplicata.

Nas amostras controle e irradiadas em acelerador de elétrons ocorreu diferença estatística entre as amostras controle, 5 e $10 \mathrm{kGy}$ e as amostras de 20,30 e $50 \mathrm{kGy}$ $(p<0,05)$. A amostra controle apresentou o maior valor de umidade.

A comparação múltipla entre as médias das amostras que receberam radiação gama indicou a diferença estatística entre as médias da amostra controle $\mathrm{e}$ as demais amostras $(p<0,05)$ e entre a amostra de $5 \mathrm{kGy}$ e as amostras de 20,30 e $50 \mathrm{kGy}$. A amostra controle apresentou o maior valor de umidade. 
A determinação da umidade pelo método de refratometria é indireto, ou seja, depende do índice de refração, que deve ser corrigido para a temperatura de $20^{\circ} \mathrm{C}$. Neste método, quanto maior o valor de ${ }^{\circ}$ Brix, maior o índice de refração e menor a umidade. As amostras irradiadas apresentaram aumento de sólidos solúveis, portanto o valor de umidade tende a diminuir nestas amostras. Este comportamento não foi observado nas amostras que receberam doses de radiação gama maior que $20 \mathrm{kGy}$ e tiveram a umidade medida pelo método direto (Karl Fischer), porém os resultados obtidos com este método e o método de refratometria estiveram bastante próximos, indicando que a refratometria pode ser uma técnica a ser utilizada para a determinação da umidade das amostras de açúcar líquido invertido.

\subsubsection{Sacarose}

Os teores de sacarose para as amostras controle e irradiadas com feixe de elétron e radiação gama estão apresentados na TAB. 16 . Os valores variaram entre $23 \%$ e $30 \%$.

TABELA 16 - Valores médios de sacarose para as amostras de açúcar líquido: controle e irradiadas em acelerador de elétrons e em fonte de cobalto-60.

\begin{tabular}{c|c|c}
\hline \multirow{2}{*}{ Dose (kGy) } & \multicolumn{2}{|c}{ Sacarose $(\%)^{*}$} \\
\cline { 2 - 3 } & $\begin{array}{c}\text { Acelerador de } \\
\text { elétrons }\end{array}$ & Fonte ${ }^{60}$ Co \\
\hline Controle & $29,58 \pm 0,63^{\mathrm{a}}$ & $27,45 \pm 0,24^{\mathrm{a}}$ \\
\hline 5 & $27,32 \pm 1,48^{\mathrm{b}}$ & $26,89 \pm 1,18^{\mathrm{a}}$ \\
\hline 10 & $25,46 \pm 0,25^{\mathrm{c}}$ & $26,71 \pm 0,34^{\mathrm{a}}$ \\
\hline 20 & $27,21 \pm 0,28^{\mathrm{b}}$ & $27,39 \pm 0,43^{\mathrm{a}}$ \\
\hline 30 & $22,81 \pm 1,17^{\mathrm{d}}$ & $26,81 \pm 0,78^{\mathrm{a}}$ \\
\hline 50 & $25,87 \pm 1,15^{\mathrm{bc}}$ & $23,71 \pm 0,08^{\mathrm{b}}$ \\
\hline
\end{tabular}

Os valores acompanhados por letras diferentes numa mesma coluna são significativamente diferentes-teste LSD.

*Análises realizadas em triplicata.

A comparação múltipla entre as médias (teste LSD) obtidas nas amostras controle e irradiadas em fonte de cobalto-60 indicou que não ocorreu diferença estatística entre as amostras, somente no xarope irradiado a $50 \mathrm{kGy}$. Nas amostras utilizadas no ensaio com acelerador de elétrons ocorreu diferença estatística entre as amostras controle, 5,10 e $30 \mathrm{kGy}$.

As amostras irradiadas pelas duas técnicas apresentaram redução no teor de sacarose em relação ao controle, indicando que ocorreu a degradação deste dissacarídeo. 
Nas amostras irradiadas em feixe de elétron, o menor teor de sacarose ocorreu na amostra de $30 \mathrm{kGy}$, enquanto que na radiação gama a amostra de $50 \mathrm{kGy}$ apresentou a maior redução.

\subsubsection{Açúcares redutores}

Os teores de glicose e frutose (açúcares redutores) estão apresentados na TAB 17, para as amostras controle e irradiadas em feixe de elétron e fonte de cobalto- 60 , respectivamente. Os valores variaram entre $48 \%$ e $53 \%$.

TABELA 17 - Valores médios de açúcares redutores (glicose e frutose) para as amostras de açúcar Vígaido: controle e irradladas em acelerador de elétrons e em fonte de cohalto-6il.

\begin{tabular}{c|c|c}
\hline \multirow{2}{*}{ Dose (kGy) } & \multicolumn{2}{|c}{ Açúcares redutores (\%) } \\
\cline { 2 - 3 } & $\begin{array}{c}\text { Acelerador de } \\
\text { elétrons }\end{array}$ & Fonte ${ }^{60} \mathrm{Co}$ \\
\hline Controle & $48,18 \pm 0,25^{\mathrm{a}}$ & $48,42 \pm 0,41^{\mathrm{a}}$ \\
\hline 5 & $49,53 \pm 0,83^{\mathrm{b}}$ & $49,39 \pm 0,30^{\mathrm{a}}$ \\
\hline 10 & $52,09 \pm 0,47^{\mathrm{c}}$ & $50,80 \pm 1,04^{\mathrm{ab}}$ \\
\hline 20 & $49,86 \pm 0,50^{\mathrm{bd}}$ & $49,53 \pm 0,68^{\mathrm{a}}$ \\
\hline 30 & $53,42 \pm 1,05^{\mathrm{e}}$ & $49,33 \pm 1,11^{\mathrm{a}}$ \\
\hline 50 & $50,90 \pm 0,98^{\text {cd }}$ & $52,59 \pm 1,10^{\mathrm{b}}$ \\
\hline
\end{tabular}

Os valores acompanhados por letras diferentes numa mesma coluna são significativamente diferentes-teste LSD.

Análises realizadas em triplicata.

A análise de variância (ANOVA) indicou a diferença estatística entre as médias ao nível de confiança de $95 \%$ (Apêndice).

$\mathrm{O}$ teor de açúcares redutores do açúcar líquido aumentou em relação às amostras controles, com a aplicação da irradiação. Nas amostras irradiadas com feixe de elétrons o maior aumento de glicose e frutose ocorreu na amostra que recebeu $30 \mathrm{kGy}$, enquanto na radiação gama o maior aumento ocorreu na amostra de $50 \mathrm{kGy}$. Comparando os resultados de glicose e frutose com os de sacarose pode se observar o comportamento antagônico. As curvas dos valores de sacarose em função dos açucares redutores foram construídas para verificar o coeficiente de correlação. As amostras utilizadas na irradiação com feixe de elétron apresentaram o coeficiente de correlação igual a 0,9618 . As amostras utilizadas no ensaio com cobalto-60 apresentaram o valor de $R^{2}=0,8347$. Estes dados indicam que a irradiação provocou a quebra da molécula de sacarose com a formação de glicose e frutose. 
A sacarose é um dissacarídeo formado pela união de dois monossacarideos:

a glicose e a frutose através de uma ligação glicosídica. A reação predominante em moléculas de sacarose presentes em solução irradiadas é a hidrólise, ou seja, quebra da ligação glicosídica. Esta reação é rápida e pode ocorrer em dois pontos diferentes da molécula como pode ser observado na FIG. 23 (Phillips, 1961; Byun et al., 1996).

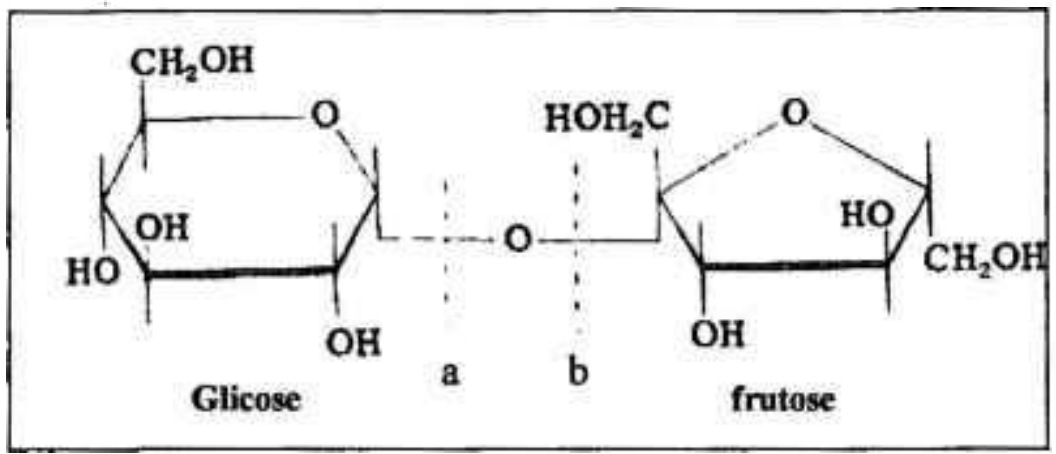

FIGURA 23 - Molécula de sacarose (Phillips, 1961).

A quebra da ligação na posição "a" leva a formação de D-frutose e ácido Dglucônico, enquanto que a quebra em "b" produz D-glicose e D-glucosona. A quebra nas duas posições ocorre na mesma proporção, portanto os quatros produtos são formados na mesma quantidade. Embora a proporção da D-glicose e D-frutose seja maior que a quantidade de ácido e D-glucosona formado (Phillips, 1961).

Outros produtos podem ser formados por processos secundários: ácido Darabino hexulosônico, D-arabinose, glioxal e ácido D-glucorônico e fragmentos aldeídicos contendo de 2 a 3 carbonos. Peróxido de hidrogênio pode ser formado continuamente e ainda, no estágio final, pode ocorrer a formação de dióxido de carbono e ácido fórmico. Os possiveis produtos formados e as principais funções químicas de cada um deles estão resumidos no esquema da FIG. 24 (Phillips, 1961). As amostras após serem irradiadas saiam da esteira transportadora do acelerador de elétrons repleta de bolhas de ar, possivelmente formadas pelo dióxido de carbono liberado durante a irradiação, ou oxigênio desprendido pelo aquecimento da amostra (Oh et al., 2004; Oh et al., 2006). 


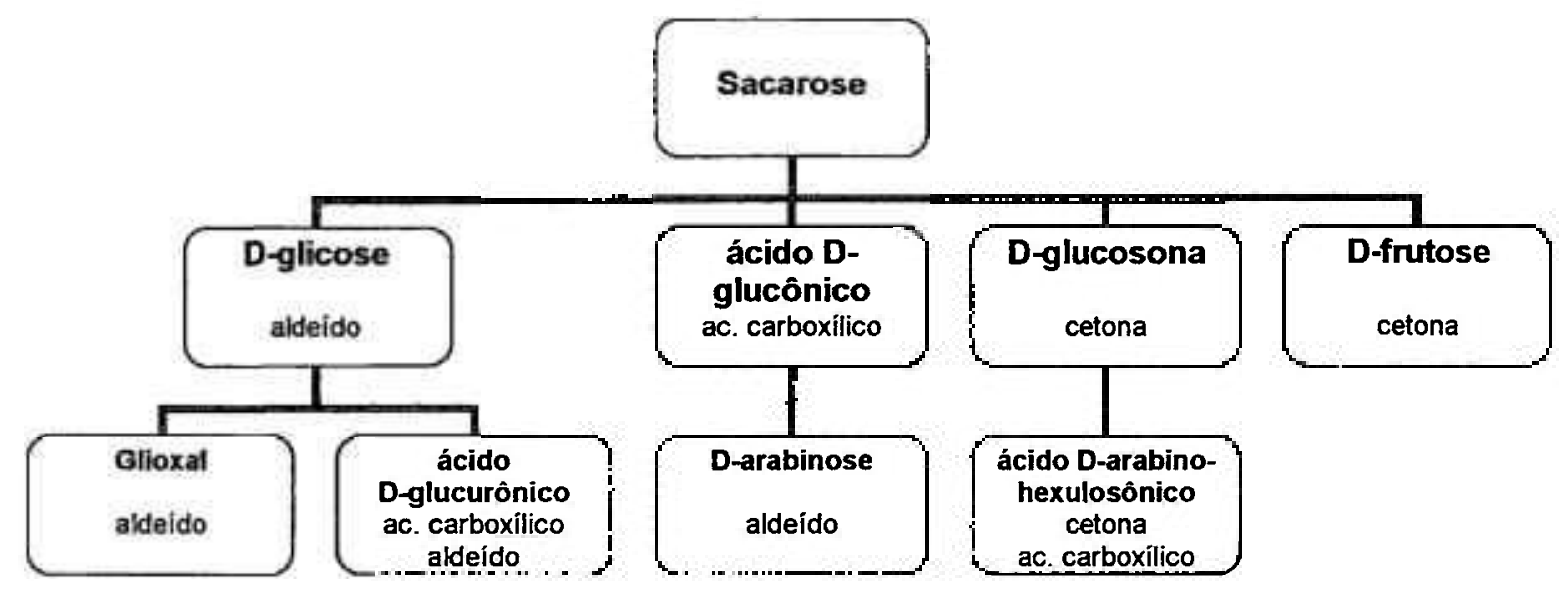

FIGURA 24 - Produtos formados a partir da degradação da sacarose irradiada (Phillips, 1961).

A formação dos ácidos D-glucônico, D-glucurônico e D-arabino hexulosônico podem ter sido os responsáveis pela queda de $\mathrm{pH}$ e aumento de sólidos solúveis que foi observado nas amostras irradiadas analisadas neste trabalho. Os ácidos formados pelo processo de irradiação podem contribuir para a hidrólise de novas moléculas de sacarose com a formação de glicose e frutose. De acordo com Phillips, 1961, a hidrólise dos açúcares aumenta proporcionalmente com a dose, portanto esperava-se obter a maior concentração de açúcares redutores à $50 \mathrm{kGy}$, na amostra que foi irradiada com feixe de elétrons porém as maiores quebras ocorreram nas amostras que receberam as doses de $10 \mathrm{e}$ $30 \mathrm{kGy}$. A amostra que recebeu a dose de $50 \mathrm{kGy}$ pode ter sofrido degradações secundárias mais complexas, levando à fragmentação da glicose e da frutose.

A glicose e a frutose, em solução, quando irradiadas sofrem ataque dos radicais em várias partes da molécula, aleatoriamente. Os produtos formados, seja na presença de oxigênio ou sob vácuo, demonstram que todas as ligações são afetadas. As reações iniciais, nestas duas atmosferas diferentes, são semelhantes, porém a presença do oxigênio pode modificar a natureza do produto final (Phillips, 1961).

\subsubsection{Cor}

$\mathrm{Na}$ TAB. 18 estão os dados de cor medidos à $420 \mathrm{~nm}$ (ICUMSA). Os valores variaram entre 19 e 81 UI. 
TABELA 18 - Valores médios de cor para as amostras de açúcar líquido: controle e irradiadas em acelerador de elétrons e em fonte de cobalto-60.

\begin{tabular}{c|c|c}
\hline \multirow{2}{*}{ Dose (kGy) } & \multicolumn{2}{|c}{ Cor (UI) } \\
\cline { 2 - 3 } & $\begin{array}{c}\text { Acelerador de } \\
\text { elétrons }\end{array}$ & Fonte ${ }^{60}$ Co \\
\hline Controle & $40 \pm 6^{\mathrm{a}}$ & $55 \pm 1^{\mathrm{a}}$ \\
\hline 5 & $23 \pm 1^{\mathrm{b}}$ & $42 \pm 1^{\mathrm{b}}$ \\
\hline 10 & $19 \pm 2^{\mathrm{b}}$ & $43 \pm 1^{\mathrm{b}}$ \\
\hline 20 & $36 \pm 1^{\mathrm{a}}$ & $49 \pm 1^{\mathrm{c}}$ \\
\hline 30 & $51 \pm 0^{\mathrm{c}}$ & $58 \pm 0^{\mathrm{d}}$ \\
\hline 50 & $81 \pm 0^{\mathrm{d}}$ & $77 \pm 0^{\mathrm{e}}$ \\
\hline
\end{tabular}

Os valores acompanhados por letras diferentes numa mesma coluna são significativamente diferentes-teste Tukey.

"Análises realizadas em triplicata.

A análise de variância (ANOVA) para a cor indicou que existe diferença estatística entre as médias ao nível de $95 \%$ de confiança (Apêndice).

O comportamento da cor foi semelhante nas amostras irradiadas com cobalto60 e com feixe de elétrons. As amostras que receberam as doses de 5, 10 e $20 \mathrm{kGy}$ apresentaram valores de cor inferiores, em relação ao controle. Enquanto que as amostras que receberam as doses de 30 e $50 \mathrm{kGy}$ aumentaram a intensidade da cor.

A cor é um dos parâmetros que pode ser utilizado como índice de qualidade para o açúcar líquido invertido. Nas amostras irradiadas observou-se, visualmente, que logo após sofrerem a irradiação, as soluções perdiam a cor característica do açúcar invertido, que é amarelo. As amostras ficaram transparentes. De acordo com Marignetti \& Mantovani, 1979, soluções de açúcar irradiadas com radiação UV sofrem redução de pH e da intensidade da cor. Com o decorrer do tempo de armazenagem, a cor inicial retornou, porém as amostras que receberam maior dose de irradiação adquiriram coloração mais escura que o amarelo característico. Este fato pode ser observado nas amostras de 30 e 50 kGy que apresentaram a intensidade da cor maior que a amostra controle. Liggett et al., 1959 reportou que soluções contendo $50 \%$ de sacarose, glicose ou frutose ficaram transparentes imediatamente após a irradiação, com doses de $50 \mathrm{kGy}$, e após armazenagem à temperatura ambiente desenvolveram a cor marrom. $\mathrm{O}$ mesmo comportamento foi observado nesta tese. A FIG. 25 mostra as amostras logo após passarem pelo processo de irradiação na fonte de cobalto-60, notou-se a ausência de cor nas amostras irradiadas. $\mathrm{Na}$ FIG. 26, estão as mesmas amostras após um ano de armazenagem à temperatura ambiente, neste caso as amostras tiveram a cor restabelecida, e as amostras que receberam as maiores doses apresentaram intensificação da cor. 
Os açúcares redutores em solução podem sofrer reações de mutação, enolização, isomerização, desidratação e fragmentação, formação de anidrido e polimerização. Algumas dessas reações, como desidratação, fragmentação e polimerização, ocorrem no escurecimento de uma solução de açúcar. O escurecimento de soluções de açúcares proporciona a formação das cores variando do amarelo ao marrom. A cor é resultante da decomposição de açúcares redutores durante o processamento, esta decomposição pode também ocorrer nos açúcares quando irradiados (Liggett, et al., 1959; Shallenberger \& Birch, 1975). Durante o processo de escurecimento são formados enóis, enedióis, redutonas e hidroximetilfurfural, estes compostos podem sofrer polimerização e resultar na formação de polímeros coloridos (Hodge, 1953; Bothner-By \& Balazs, 1957; Liggett et al., 1959; Shallenberger \& Birch, 1975). Os enedióis são compostos que possuem dois grupos hidroxilas ligados a dois carbonos que possuem entre sí uma ligação dupla e as redutonas são compostos contendo um grupo enediol estabilizado por um grupo carbonila.

$\mathrm{O}$ processo de escurecimento ocorre em temperaturas superiores à $100{ }^{\circ} \mathrm{C}$ ou em soluções concentradas de açúcares (Hodge, 1953; Shallenberger \& Birch, 1975). Em geral, a reação é favorecida em $\mathrm{pH}$ alcalino, podendo ocorrer em $\mathrm{pH}$ ácido a uma velocidade menor (Oh et al., 2006). Vale a pena ressaltar, que em pH entre 3,8 e 4,5 a frutose é mais reativa que a glicose no desenvolvimento da cor (Gonzáles et al., 1999). Soluções de açúcar irradiadas com ultravioleta e com pH menor que 3,0 apresentaram mudança de cor mais acentuada quando comparadas com soluções de mesmo pH e que não passaram pelo processo de irradiação. Entretanto, soluções de açúcar irradiadas e com pH menor que 6,0 apresentaram mudança de cor discreta quando comparadas com a amostra controle. Desta forma, para minimizar alterações de cor recomenda-se que soluções irradiadas sejam armazenadas com pH entre 4,0 e 6,0 (Davis e Prince, 1955; Marignetti \& Mantovani, 1979/80).

A amostra de açúcar irradiada com a maior dose no acelerador de elétrons ( 50 kGy) teve a maior alteração na cor, com aumento de $100 \%$ em relação ao controle. Este fato somado ao $\mathrm{pH}$ desta solução, que foi menor que 3,0 , podem ter contribuído para essa mudança expressiva. Vale a pena ressaltar que as mudanças na intensidade da cor das amostras irradiadas estão dentro do padrão especificado pela empresa que forneceu as amostras do xarope invertido 


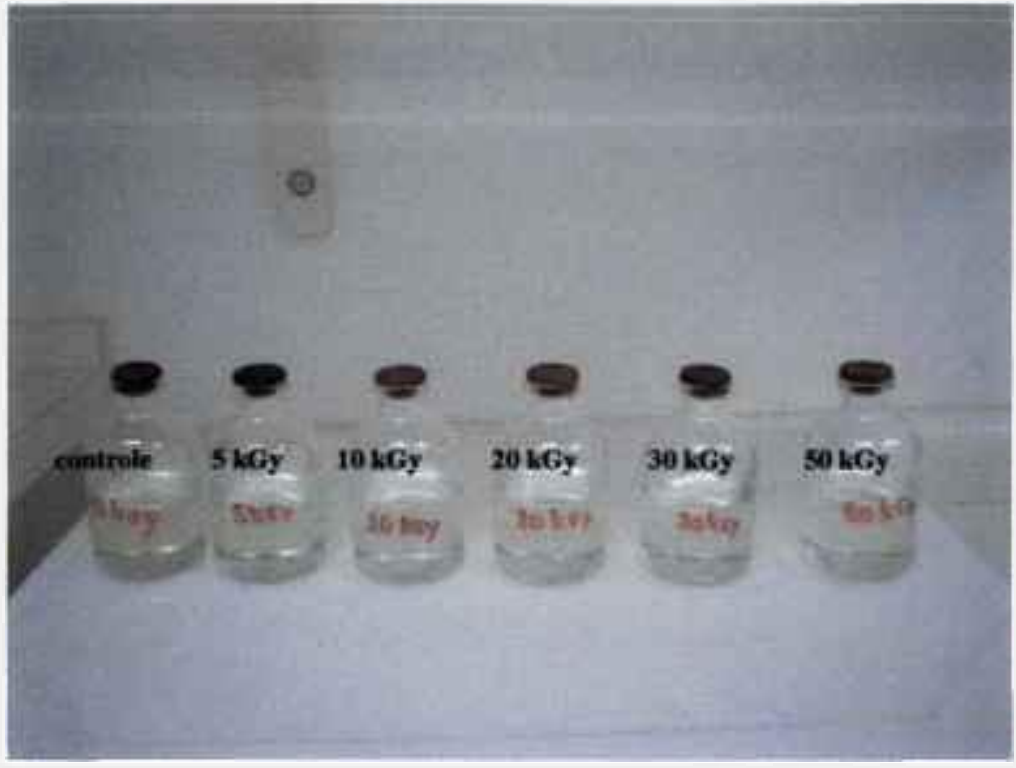

FIGURA 25 - Amostras de açúcar invertido logo após a irradiação em fonte de cobalto-60. Amostras controle e irradiadas em doses de $5,10,20,30$ e $50 \mathrm{kGy}$.

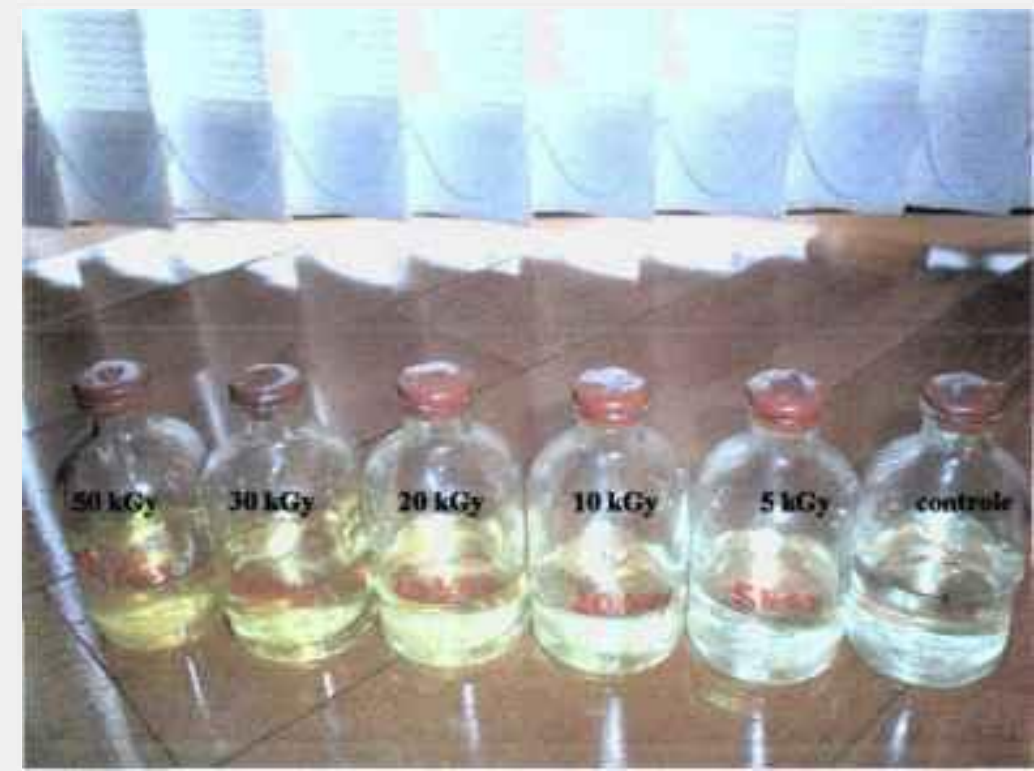

FIGURA 26 - Amostras de açúcar invertido irradiado em fonte de cobalto-60 após um ano de armazenagem a temperatura ambiente e na presença de luz. Amostras controle e irradiadas em doses de $5,10,20,30$ e $50 \mathrm{kGy}$.

\subsubsection{Hidroximetilfurfural (HMF)}

Na TAB. 19 estão os valores medidos de hidroximetilfurfural (HMF) para o açúcar líquido invertido. Os valores apresentaram grande variação, entre 3 e $27 \mathrm{mg} / \mathrm{kg}$. 
TABELA 19 - Valores médios de hidroximetilfurfural (HMF) para as amostras de açúcar líquido: controle e irradiadas em acelerador de elétrons e em fonte de cobalto-60.

\begin{tabular}{c|c|c}
\hline \multirow{2}{*}{ Dose (kGy) } & \multicolumn{2}{|c}{ HMF (mg/kg) } \\
\cline { 2 - 3 } & $\begin{array}{c}\text { Acelerador de } \\
\text { elétrons }\end{array}$ & Fonte ${ }^{60}$ Co \\
\hline Controle & $21 \pm 4^{\mathrm{a}}$ & $27 \pm 2^{\mathrm{a}}$ \\
\hline 5 & $7 \pm 1^{\mathrm{b}, \mathrm{c}}$ & $14 \pm 4^{\mathrm{b}}$ \\
\hline 10 & $5 \pm 1^{\mathrm{c}}$ & $5 \pm 0^{\mathrm{c}}$ \\
\hline 20 & $3 \pm 1^{\mathrm{c}}$ & $10 \pm 1^{\mathrm{bc}}$ \\
\hline 30 & $12 \pm 0^{\mathrm{b}}$ & $8 \pm 2^{\mathrm{bc}}$ \\
\hline 50 & $27 \pm 4^{\mathrm{a}}$ & $12 \pm 3^{\mathrm{bc}}$ \\
\hline
\end{tabular}

Os valores acompanbados por letras diferentes numa mesma coluna sã̃o significativamente diferentes-teste Tukey.

*Análises realizadas em triplicata.

Segundo a análise de variância (ANOVA) existe diferença estatística entre as médias ao nível de $95 \%$ de confiança (Apêndice).

$\mathrm{Na}$ fabricação do açúcar líquido invertido, a sacarose sofre decomposição ácida para a liberação da glicose e frutose, dependendo das condições que essa reação é conduzida pode ocorrer a formação de HMF. Fatores que acentuam a formação de HMF são as temperaturas elevadas, o tempo prolongado de reação e o $\mathrm{pH}$ ácido (Tosi et al., 2002; Sanz et al., 2003; Xu et al., 2003; Fallico et al., 2004; Mendoza et al., 2004; Oh et $a l ., 2004)$. O HMF é um produto indesejado já que a sua degradação pode levar a formação de produtos poliméricos coloridos, afetando a cor do xarope (Hodge, 1953; Liggett et al., 1959). O conteúdo de HMF em méis após processamento e ou mistura não deve ser superior à $40 \mathrm{mg} / \mathrm{kg}$, com exceção de méis provenientes de regiões tropicais em que o conteúdo de HMF não deve ser superior a $80 \mathrm{mg} / \mathrm{kg}$ (Fallico et al., 2004). Para o açúcar líquido invertido não há legislação que limite o teor de HMF.

As amostras irradiadas à 5, 10, 20 e $30 \mathrm{kGy}$ apresentaram os valores médios de HMF inferiores ao controle. Possivelmente, a irradiação provocou a quebra do HMF, uma vez que o HMF sendo sensível à radiação ultravioleta, é provável que o seja à radiação por feixe de elétrons e gama (Wunderlin et al., 1998), contradizendo os dados obtidos por Oh et al., 2004 que observaram aumento na absorbância no comprimento de onda típico do HMF em soluções de sacarose, glicose e frutose (1M) irradiadas à 10,20 e $30 \mathrm{kGy}$. $\mathrm{O}$ aumento na absorbância foi proporcional ao aumento da dose.

A amostra que foi irradiada com feixe de elétrons na dose de $50 \mathrm{kGy}$ aumentou substancialmente o teor de HMF. Para receber a doses de 30 e $50 \mathrm{kGy}$ a amostra passou pelo feixe de elétrons 6 e 10 vezes, respectivamente, a cada passagem a dose recebida foi 
de $5 \mathrm{kGy}$ e nestas passagens a temperatura em média era de $40,5^{\circ} \mathrm{C}$. A elevação de temperatura associada ao $\mathrm{pH}$ ácido da solução pode ter contribuído para a formação de novas moléculas de HMF, outro fato citado na literatura que pode ter contribuído para o valor elevado de HMF é a presença da frutose, que está em maior quantidade nas amostras irradiadas, decorrente da degradação da sacarose; este açúcar pode contribuir para a proteção do HMF em solução evitando a sua degradação (Wunderlin et al., 1998).

\subsubsection{Varredura na reglão do ultravioleta}

A varredura do xarope invertido foi realizada na região do ultravioleta. As soluções apresentaram absorbâncias máximas em comprimentos de onda variando entre 273 e $284 \mathrm{~nm}$, como pode ser observado na TAB. 20.

TABELA 20 - Valores de comprimento de onda e absorbância para as amostras controle e irradiadas de açúcar líquido invertido em diferentes doses $\mathrm{em}$ acelerador de elétrons e fonte de cobalto-60.

\begin{tabular}{c|c|c|c|c}
\hline \multirow{2}{*}{ Dose (kGy) } & \multicolumn{2}{|c|}{ Acelerador de elétrons } & \multicolumn{2}{c}{ Fonte cobalto-60 } \\
\cline { 2 - 5 } & $\begin{array}{c}\text { Comprimento de } \\
\text { onda (nm) }\end{array}$ & Absorbância & $\begin{array}{c}\text { Comprimento de } \\
\text { onda (nm) }\end{array}$ & Absorbância \\
\hline Controle & 284 & 0,42 & 283 & 0,73 \\
\hline 5 & 276 & 0,49 & 283 & 0,48 \\
\hline 10 & 273 & 0,65 & 278 & 0,51 \\
\hline 20 & 274 & 1,05 & 274 & 0,57 \\
\hline 30 & 275 & 1,43 & 275 & 0,61 \\
\hline 50 & 278 & 1,92 & 274 & 0,92 \\
\hline
\end{tabular}

Para o ensaio no acelerador de elétrons, o espectro do ultravioleta da amostra controle mostrou a máxima absorção no comprimento de onda de $284 \mathrm{~nm}$, característico do hidroximetilfurfural (HMF) (Wunderlin et al.,1998). Vale a pena ressaltar, que o xarope que serviu de controle apresentou valor elevado de HMF: $21 \mathrm{mg} / \mathrm{kg}$ (TAB. 19).

As amostras irradiadas a 5, 10, 20 e $30 \mathrm{kGy}$ apresentaram comprimentos de onda variando entre 273 e $283 \mathrm{~nm}$. Esta pequena mudança no comprimento de onda pode ser decorrente da variação de $\mathrm{pH}$ que ocorreu entre as amostras (Liggett et al., 1959). Nas amostras irradiadas a $5,10,20$ e $30 \mathrm{kGy}$, o valor de $\mathrm{HMF}$ não teve contribuição importante, indicando que os produtos formados pela irradiação são os responsáveis pelo perfil de absorção apresentado, uma vez que a absorbância aumentou proporcionalmente com o aumento da dose recebida $\left(\mathrm{R}^{2}=0,9891\right)$. 
A concentração elevada de HMF na amostra de $50 \mathrm{kGy}$ não contribuiu para elevada absorção no espectro dessa solução a $284 \mathrm{~nm}$, uma vez que a máxima absorção ocorreu a $278 \mathrm{~nm}$, indicando que os produtos resultantes da irradiação tiveram maior contribuição.

As soluções de carboidratos irradiadas apresentam a absorção máxima entre 260-290 nm (Phillips, 1961). Nas soluções de carboidratos irradiadas ocorre a formação de redutonas que absorvem na faixa de UV descrita (Bothner-By \& Balazs, 1957; Liggett et al., 1959). Compostos contendo esses grupamentos são intermediários na formação do pigmento caramelo, que resultará no aumento da intensidade da cor da solução. Este pigmento possui em sua estrutura grupos carbonilas e enólicos (Hodge, 1953; Shallenberger \& Birch, 1975; Bobbio e Bobbio, 2001). Vale a pena ressaltar que a quebra da molécula de sacarose, devido a irradiação, resulta na formação de compostos com os grupamentos: aldeído, cetona e carboxílico, como foi mostrado no esquema apresentado na FIG. 24. Todos esses grupamentos absorvem na faixa entre 250-360 nm (Pavia et al., 1996). Portanto, é possível que os comprimentos de onda nos quais ocorreram as máximas absorbâncias, nas amostras de açúcar invertido irradiado, sejam formados por um conjunto de compostos decorrente da degradação do açúcar ou a formação de compostos poliméricos coloridos.

\subsubsection{Viscosidade}

As médias de viscosidade para o xarope invertido estão representadas na TAB.

21 .

TABELA 21 - Valores médios de viscosidade para as amostras controle e irradiadas de açúcar líquido invertido em diferentes doses em acelerador de elétrons e fonte de cobalto-60.

\begin{tabular}{c|c|c}
\hline \multirow{2}{*}{ Dose $(\mathrm{kGy})$} & \multicolumn{2}{|c}{ Viscosidade (cP) } \\
\cline { 2 - 3 } Controle & Acelerador de elétrons & Fonte de cobalto-60 \\
\hline 5 & $2799 \pm 15^{\mathrm{a}}$ & $2371 \pm 75^{\mathrm{a}}$ \\
\hline 10 & $2507 \pm 13^{\mathrm{b}}$ & $2541 \pm 86^{\mathrm{b}}$ \\
\hline 20 & $2542 \pm 18^{\mathrm{c}}$ & $2535 \pm 60^{\mathrm{b}}$ \\
\hline 30 & $2717 \pm 12^{\mathrm{d}}$ & $2557 \pm 119^{\mathrm{b}}$ \\
\hline 50 & $2715 \pm 11^{\mathrm{d}}$ & $2566 \pm 154^{\mathrm{b}}$ \\
\hline
\end{tabular}

Os valores acompanhados por letras diferentes numa mesma coluna são significativamente diferentes-teste Tukey.

"Análises realizadas em triplicata. $\mathrm{cP}=$ centipoise. 
A análise de variância (ANOVA-Apêndice) indicou que ocorreu diferença estatística entre as médias ao nível de $95 \%$ de confiança.

Pode-se observar que os valores de viscosidade das amostras controle do lote usado para a irradiação com feixe de elétrons e do lote de cobalto-60 apresentaram variação maior que as amostras que passaram pelo processo de irradiação. A irradiação gerou alterações na viscosidade da amostra menores que as ocorridas nas amsotras controle de lotes diferentes. A irradiação do xarope invertido nas doses estudadas não compromete o processamento do açúcar invertido, já que a viscosidade é um fator fundamental na escolha de válvulas, bombas e equipamentos.

$\mathrm{O}$ número de reações que podem ocorrer entre os radicais formados pela irradiação e as moléculas de açúcar são inúmeras. As reações mais significativas que podem ocorrer após a irradiação são: a quebra da ligação glicosídica da molécula de sacarose, liberando a glicose e a frutose, o que resultaria em uma diminuição da viscosidade da solução; e a dimerização através de uma reação radical-radical. Neste último caso, a viscosidade tenderia a aumentar. Vale ressaltar, que as reações podem ocorrer simultaneamente (Phillips, 1961).

As amostras que receberam as doses de 5 e $10 \mathrm{kGy}$, no acelerador de elétrons apresentaram viscosidades bastante próximas, porém estatisticamente diferentes e menores que a amostra controle, indicando que nestas amostras prevaleceu a quebra dos açúcares. A irradiação pode levar a quebra das moléculas de sacarose com a formação dos açúcares redutores que são moléculas menores e a quebra desses monossacarídeos também pode resultar, ainda, na formação de compostos com cadeias menores que seis carbonos.

As amostras de 20 e $30 \mathrm{kGy}$ apresentaram viscosidade de $2716 \mathrm{cP}$, este valor está próximo ao controle, porém nota-se um aumento da viscosidade em relação aos xaropes que receberam as doses de 5 e $10 \mathrm{kGy}$, nestas amostras deve estar ocorrendo reação de quebra e polimerização à mesma velocidade.

O maior valor de viscosidade média foi observado no xarope irradiado a 50 kGy. As maiores doses de irradiação são responsáveis pela formação de um número maior de radicais levando a provocar quebras em maior número de moléculas de açúcar, assim como em mais pontos da mesma molécula. A maior quantidade de compostos com cadeia pequena interagindo em solução, pode levar a reação entre eles e dessa maneira formar compostos com cadeia com maior número de carbonos, contribuindo para a elevação da viscosidade (Snell, 1965; Aliste et. al., 2000). 
Vale a pena ressaltar, que na dose de $50 \mathrm{kGy}$ ocorreu a maior formação de cor como já discutido, os compostos responsáveis pela cor são compostos de cadeia longa e por essa razão podem ter contribuído para o aumento da viscosidade.

Os resultados experimentais comprovaram que o xarope invertido apresenta comportamento reológico newtoniano nas amostras controle e irradiadas, na temperatura estudada $\left(24,6 \pm 0,1^{\circ} \mathrm{C}\right)$. Os reogramas para cada uma das doses foram construídos e estão mostrados na FIG. 27. Os coeficientes de correlação obtidos foram superiores à 0,9983 , como pode ser observado na TAB. 22.

Em relação às amostras utilizadas no ensaio com cobalto- 60 , os valores das viscosidades médias das amostras irradiadas foram maiores que os valores obtidos com a amostra controle. Os valores de viscosidade média não apresentaram diferença estatística entres as amostras que foram irradiadas, portanto se está ocorrendo a formação de dímeros eles não são influência direta da dose de radiação recebida pela amostra.

O estudo reológico comprovou o comportamento newtoniano do açúcar líquido invertido das amostras controle e irradiadas com radiação gama, como pode ser observado na FIG. 28.

Para as amostras que receberam a radiação gama, o gráfico da FIG. 28 resume as medidas realizadas no terceiro dia de ensaio. $\mathrm{O}$ coeficiente de correlação para todas as doses estudadas inclusive no controle foi de 1 . Nos dois primeiros dias de análise os coeficientes de correlação variaram entre 0,9965 e 1 . As equações das retas para o terceiro dia de ensaio está resumido na TAB. 23.

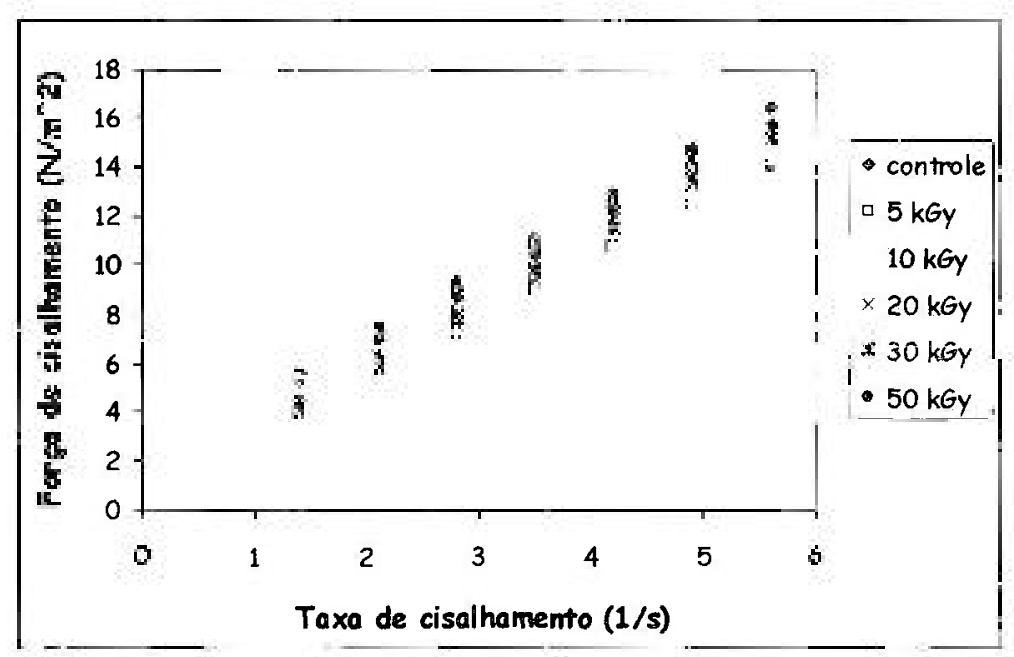

FIGURA 27 - Reogramas do açúcar líquido invertido à $24,6 \pm 0,1^{\circ} \mathrm{C}$ para a amostra controle e para as amostras irradiadas em acelerador de elétron nas doses de $5,10,20,30$ e $50 \mathrm{kGy}$. 
TABELA 22 - Equação da reta e coeficientes de correlação para as diferentes doses recebidas pelo aruicur biquido invertido irradiado com feize de elétrons.

\begin{tabular}{c|c|c}
\hline Dose $(\mathrm{kGy})$ & Equação da reta & Coeficiente de correlação \\
\hline 0 & $2,4606 \mathrm{x}+1,9962$ & 0,9986 \\
\hline 5 & $2,4153 \mathrm{x}+0,6164$ & 0,9991 \\
\hline 10 & $2,5785 \mathrm{x}-0,0292$ & 0,9983 \\
\hline 20 & $2,6622 \mathrm{x}+0,5003$ & 0,9998 \\
\hline 30 & $2,5791 \mathrm{x}+0,7921$ & 0,9993 \\
\hline 50 & $2,6179 \mathrm{x}+1,793$ & 0,9988 \\
\hline
\end{tabular}

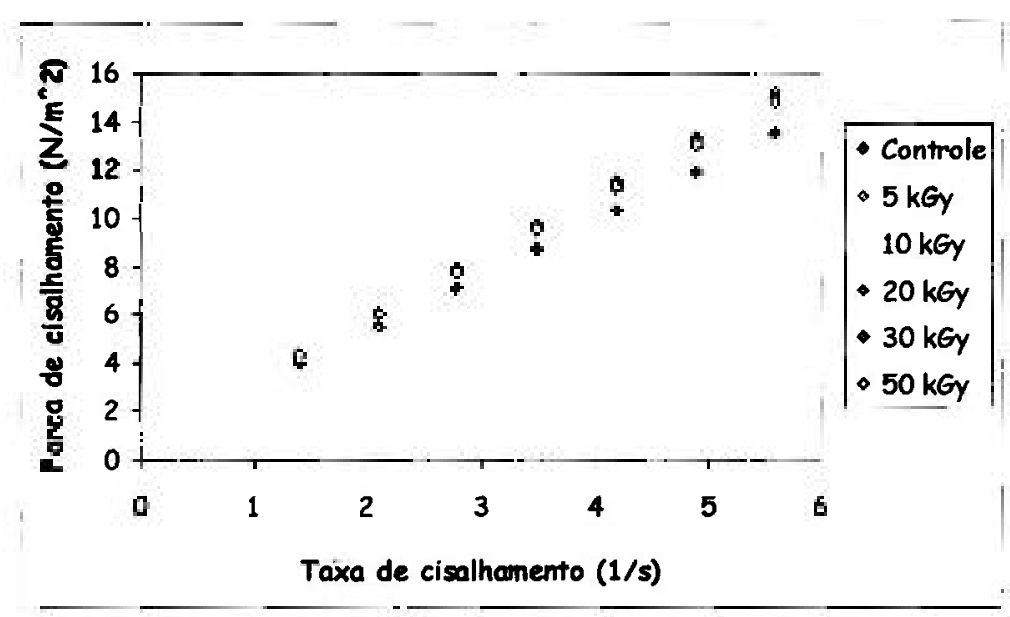

FIGURA 28 - Reogramas do açúcar líquido invertido à $24,6 \pm 0,2{ }^{\circ} \mathrm{C}$ para a amostra controle $\mathrm{e}$ para as amostras irradiadas em fonte de cobalto-60 nas doses de 5, 10, 20, 30 e 50 kGy.

TABELA 23 - Equação da reta e coeficientes de correlação para as diferentes doses recebidas pelo acúcar líquido invertido irradiado com fonte de cobalto-60.

\begin{tabular}{c|c}
\hline Dose (kGy) & Equação da reta \\
\hline 0 & $2,2838 x+0,7456$ \\
\hline 5 & $2,4878 x+0,7156$ \\
\hline 10 & $2,4535 x+0,7492$ \\
\hline 20 & $2,5829 x+0,7234$ \\
\hline 30 & $2,5495 x+0,6917$ \\
\hline 50 & $2,5126 x+0,7222$ \\
\hline
\end{tabular}

\subsection{Análise Microbiológica}

$\mathrm{Na}$ TAB. 24 estão os valores médios de contagem de bolores e leveduras obtidos através da análise microbiológica nas amostras de açúcar invertido que receberam as doses de 0 (controle), 5, 10,20,30 e $50 \mathrm{kGy}$, em fonte de raios gama. A análise microbiológica foi conduzida durante a vida de prateleira do produto que era de 6 meses. Após esse período, a contagem de bolores e leveduras continuou por mais três meses com 
o intervalo de 15 dias entre as análises. Em função dos resultados obtidos com os raios gama, não foi realizado o ensaio microbiológico com o feixe de elétrons.

TABELA 24 - Resultados da contagem de bolores e leveduras para 0 açúcar líquido invertido, controle e irradiado com raios gama, durante o período de 9,5 meses. UFC: Unidades formadoras de colônia.

\begin{tabular}{|c|c|c|c|c|c|c|}
\hline Armazenamento & \multicolumn{6}{|c|}{$\operatorname{DOSE}(k G y)$} \\
\hline 1 mês & 0 & 5 & 10 & 20 & 30 & 50 \\
\hline Bolores (UFC/mL) & $<10$ & $<10$ & $<10$ & $<10$ & $<10$ & $<10$ \\
\hline $\begin{array}{l}\text { Leveduras } \\
\text { (UFC/mL) }\end{array}$ & $<10$ & $<10$ & $<10$ & $<10$ & $<10$ & $<10$ \\
\hline 2 meses & 0 & 5 & 10 & 20 & 30 & 50 \\
\hline Bolores (UFC/mL) & $<10$ & $<10$ & $<10$ & $<10$ & $<10$ & $<10$ \\
\hline $\begin{array}{l}\text { Leveduras } \\
\text { (UFC/mL) }\end{array}$ & $<10$ & $<10$ & $<10$ & $<10$ & 50 & $<10$ \\
\hline 5 meses & 0 & 5 & 10 & 20 & 30 & 50 \\
\hline Bolores (UFC/mL) & $<10$ & $<10$ & $<10$ & $<10$ & $<10$ & $<10$ \\
\hline $\begin{array}{l}\text { Leveduras } \\
\text { (UFC/mL) }\end{array}$ & $<10$ & $<10$ & $<10$ & $<10$ & $<10$ & $<10$ \\
\hline 6 meses & 0 & 5 & 10 & 20 & 30 & 50 \\
\hline Bolores (UFC/mL) & $<10$ & $<10$ & $<10$ & $<10$ & $<10$ & $<10$ \\
\hline $\begin{array}{l}\text { Leveduras } \\
\text { (UFC/mL) }\end{array}$ & $<10$ & $<10$ & $<10$ & $<10$ & $<10$ & $<10$ \\
\hline 7 meses & 0 & 5 & 10 & 20 & 30 & 50 \\
\hline Bolores (UFC/mL) & 10 & 10 & 10 & $<10$ & $<10$ & 10 \\
\hline $\begin{array}{l}\text { Leveduras } \\
\text { (UFC/mL) }\end{array}$ & $<10$ & $<10$ & $<10$ & $<10$ & $<10$ & $<10$ \\
\hline 7,5 meses & 0 & 5 & 10 & 20 & 30 & 50 \\
\hline Bolores (UFC/mL) & $<10$ & $<10$ & $<10$ & $<10$ & $<10$ & $<10$ \\
\hline $\begin{array}{l}\text { Leveduras } \\
\text { (UFC/mL) }\end{array}$ & $<10$ & $<10$ & $<10$ & $<10$ & $<10$ & $<10$ \\
\hline 8 meses & 0 & 5 & 10 & 20 & 30 & 50 \\
\hline Bolores (UFC/mL) & $<10$ & $<10$ & $<10$ & $<10$ & $<10$ & $<10$ \\
\hline $\begin{array}{l}\text { Leveduras } \\
\text { (UFC/mL) }\end{array}$ & $<10$ & $<10$ & $<10$ & $<10$ & $<10$ & $<10$ \\
\hline 8,5 meses & 0 & 5 & 10 & 20 & 30 & 50 \\
\hline Bolores (UFC/mL) & $\leq 10$ & $<10$ & $<10$ & $<10$ & $<10$ & $<10$ \\
\hline $\begin{array}{l}\text { Leveduras } \\
\text { (UFC/mL) }\end{array}$ & $<10$ & $<10$ & $<10$ & $<10$ & $<10$ & $<10$ \\
\hline 9 meses & 0 & 5 & 10 & 20 & 30 & 50 \\
\hline Bolores (UFC/mL) & $<10$ & $<10$ & $\leq 10$ & $<10$ & $<10$ & $<10$ \\
\hline $\begin{array}{l}\text { Leveduras } \\
\text { (UFC/mL) }\end{array}$ & $<10$ & $<10$ & $<10$ & $<10$ & $<10$ & $<10$ \\
\hline 9,5 meses & 0 & 5 & 10 & 20 & 30 & 50 \\
\hline Bolores (UFC/mL) & $<10$ & $<10$ & $<10$ & $<10$ & $<10$ & $<10$ \\
\hline $\begin{array}{l}\text { Leveduras } \\
\text { (UFC/mL) }\end{array}$ & $<10$ & $<10$ & $<10$ & $<10$ & $<10$ & $<10$ \\
\hline
\end{tabular}


As análises realizadas 1 e 2 meses após a produção do açúcar foram feitas nas diluições de $10^{-1}, 10^{-2}$ e $10^{-3}$, nestas diluições não foram encontradas colônias de bolores ou leveduras, com exceção da amostra que recebeu a dose de $30 \mathrm{kGy}$, a qual apresentou 50 $\mathrm{UFC} / \mathrm{mL}$. Até completar o tempo de vida de prateleira do açúcar todas as análises resultaram em menos que $10 \mathrm{UFC} / \mathrm{mL}$. As amostras que ficaram armazenadas durante 7 meses, apresentaram $10 \mathrm{UFC} / \mathrm{mL}$ no controle e nas amostras que receberam as doses de 5 , 10 e $50 \mathrm{kGy}$. E as amostras que ficaram armazenadas de 7,5 á 9,5 meses novamente resultaram em $<10 \mathrm{UFC} / \mathrm{mL}$.

Não foi possível observar o benefício da radiação sobre o crescimento de bolores e leveduras durante o período de 9,5 meses de acompanhamento. $O$ açúcar invertido tem alto teor de sólidos solúveis, portanto o crescimento de microrganismos neste produto é dificil, porém durante o processo de produção deste ingrediente existem pontos que podem gerar a contaminação. No armazenamento, o contato com ar que não foi esterilizado, ou a diluição da superficie com a redução da pressão osmótica do açúcar podem contribuir para o desenvolvimento de microrganismos, que estavam na forma de esporos. Assim, no controle de qualidade do açúcar inclui-se a análise microbiológica.

\subsection{Análise sensorial}

A análise sensorial foi realizada com as amostras controle e irradiadas em feixe de elétrons e radiação gama. $\mathrm{Na}$ análise sensorial foi escolhida a menor dose deste estudo, $5 \mathrm{kGy}$, uma vez que essa dose é utilizada em alimentos e pode ser aplicada em escala comercial de forma economicamente viável.

\subsubsection{Irradiação com feixe de elétrons}

A análise sensorial foi conduzida através de um teste triangular com as amostras de açúcar invertido controle e irradiado com a dose de $5 \mathrm{kGy}$ em feixe de elétrons. $O$ teste foi aplicado a 30 provadores: 14 homens, 14 mulheres e 2 pessoas que não se identificaram. Dezesseis julgadores acertaram a amostra diferente dentre as três amostras apresentadas.

Através do número total de julgadores e de respostas corretas, utilizou-se a tabela apresentada em O'Mahony, 1986 e concluiu-se que ocorreu diferença significativa 
entre a amostra irradiada com $5 \mathrm{kGy}$ em feixe de elétrons e a amostra não irradiada (controle), ao nível de 5\% de significância.

Entre os provadores, $17 \%$ concluíram que as amostras eram muito parecidas no sabor. Dentre os que acertaram a resposta ocorreram observações contraditórias, 19\% comentaram que a amostra irradiada era mais doce, enquanto $31,3 \%$ concluíram que a amostra irradiada era menos doce. Apesar dos ensaios físico-químicos indicarem que o teor de açúcares redutores é $2 \%$ maior na amostra irradiada e, portanto tenderia a ser mais doce. Vale a pena acrescentar, que a doçura é difícil de ser medida e muitas vezes subjetiva. Dois provadores fizeram a observação que as amostra irradiada tinham o sabor de mel. E um provador acrescentou que a viscosidade e cor das amostras eram idênticas.

As alterações físico-químicas geradas na amostra que recebeu a dose de $5 \mathrm{kGy}$ no acelerador de elétrons é bastante sutil quando comparado ao controle, apesar da análise sensorial indicar a diferença entre a amostras irradiada e controle os comentários escritos pelos julgadores mostraram a dificuldade em notar essa diferença, bem como o discernimento entre a amostra mais doce e menos doce.

\subsubsection{Irradiação com cobalto-60}

A análise sensorial foi realizada com a amostra controle e irradiada com a dose de $5 \mathrm{kGy}$ em fonte de cobalto-60. $\mathrm{O}$ teste triangular foi aplicado a 30 provadores: 10 mulheres, 17 homens e 3 pessoas que não se identificaram. Dezessete provadores acertaram a amostra diferente dentre as três apresentadas.

Através do número total de julgadores e de respostas corretas, utilizou-se a tabela apresentada em O'Mahony, 1986 e concluiu-se que ocorreu diferença significativa entre as amostras irradiadas com radiação gama $(5 \mathrm{kGy})$ das amostras não irradiada (controle), ao nível de 5\% de significância.

Entre todos os participantes, $13 \%$ consideraram as amostras muito parecidas e, portanto dificil apontar a amostra com sabor diferente. Entre os provadores que apontaram a amostra diferente corretamente, $29 \%$ indicaram o controle como mais doce que a amostra irradiada, enquanto que $12 \%$ consideraram a amostra irradiada mais doce. Um provador considerou o controle com sabor diferente, sem especificar. Dois participantes consideraram a amostra parecida com mel.

A amostra que recebeu a dose de $5 \mathrm{kGy}$ em fonte de ${ }^{60} \mathrm{Co}$ não apresentou alterações significativas nas propriedades físico-químicas em relação ao controle. $O$ teor de 
açucares redutores da amostra irradiada foi de $2 \%$ a mais que a amostra controle, esperava-se, portanto que o seu sabor fosse mais doce, porém na análise sensorial, 5 provadores concluíram que a amostra controle era a mais doce. $O$ mesmo resultado foi repetido no ensaio com a amostra irradiada em acelerado de elétrons. A análise sensorial indicou a diferença significativa entre as amostras, porém os provadores observaram a dificuldade que tiveram em indicar a amostra diferente. 


\section{CONCLUSÕES}

- O valor médio da densidade para as amostras controle e irradiadas permaneceram próximo a $1,4 \mathrm{~g} / \mathrm{mL}$. Este comportamento foi observado para a radiação gama $\mathrm{e}$ para o feixe de elétrons.

- O teor de sólidos solúveis apresentou aumento em função da dose recebida para as amostras irradiadas em acelerador de elétrons. Nas amostras irradiadas com cobalto-60 ocorreu aumento do valor de ${ }^{0}$ Brix da amostra controle até a amostra de $20 \mathrm{kGy}$. As amostras de 30 e $50 \mathrm{kGy}$ mantiveram valor constante.

- Os valores de $\mathrm{pH}$ apresentaram redução com o aumento da dose de radiação, para as duas técnicas de radiação utilizadas neste trabalho, indicando que ocorreu a degradação dos açúcares com a formação de compostos ácidos.

- Os valores de umidade média medidos pelo método de Karl Fischer nas amostras irradiadas com feixe elétrons não apresentaram diferença estatística em função da dose. Com a radiação gama, as amostras que receberam as doses de 20, 30 e 50 kGy apresentaram aumento da umidade.

- Os valores de umidade média medido pelo método de refratometria apresentaram valores próximos ao método de Karl Fischer, indicando ser um método alternativo para a determinação da umidade do açúcar invertido.

- Os teores de sacarose, na irradiação com acelerador de elétrons e com cobalto-60, apresentaram decréscimo nas amostras irradiadas, enquanto que os valores de açúcares redutores aumentaram, indicando que a radiação provoca a quebra da ligação glicosídica da sacarose com a formação de glicose e frutose.

- As amostras que receberam as dose de 30 e $50 \mathrm{kGy}$ apresentaram a cor mais intensa, provavelmente decorrente da formação de pigmentos coloridos. Estes pigmentos contêm em sua estrutura grupamentos carbonilas e carboxilas que apresentam a máxima absorção em comprimentos de onda variando entre 250-360 nm. 
- Os valores de hidroximetilfurfural foram altos para as amostras controle. $\mathrm{Na}$ amostra que recebeu a dose de $50 \mathrm{kGy}$, o valor de $\mathrm{HMF}$ voltou a aumentar. $\mathrm{O}$ aumento pode ter decorrido da maior presença de frutose nessa amostra que protegeu o a molécula de HMF, ou as condições mais ácida da amostra propiciaram a formação de novas moléculas de HMF.

- O acompanhamento microbiológico para bolores e leveduras durante o período de 9,5 meses não permitiu concluir se a radiação gama foi eficiente na redução microbiana.

- A análise sensorial, através do teste triangular, indicou que ocorreu diferença significativa, ao nível de 5\%, no sabor do açúcar invertido irradiado com 5 kGy pelas duas técnicas de preservação, em relação ao controle.

A radiação gama e por feixe de elétrons propiciaram mudanças nas propriedades físico-químicas das amostras, porém não foram suficientes para gerar efeitos negativos no ingrediente, principalmente na dose de $5 \mathrm{kGy}$. $\mathrm{Na}$ análise sensorial, os provadores identificaram diferença entre a amostra controle e irradiada apesar de não apontarem nenhuma observação negativa em relação ao sabor, como a literatura relata que ocorre com a radiação ultravioleta.

Em relação à técnica de processamento, o acelerador de elétrons se aplicaria melhor as necessidades da indústria, especialmente em função da quantidade de açúcar que é processada diariamente.

Trabalhos futuros poderiam incluir uma comparação entre a radiação ultravioleta e por feixe de elétrons. Além da inoculação de amostras e posterior radiação para verificar o efeito da irradiação por feixe de elétrons na redução microbiana. 


\section{APÊNDICE-TRATAMENTO ESTATÍSTICO DO AÇÚCAR INVERTIDO}

Abaixo seguem as análises de variância ANOVA aplicadas nas análises físicoquímicas realizadas nas amostras irradiadas em acelerador e elétrons e fonte de cobalto- 60 .

TABELA 25 - Análise de variância (ANOVA) para os valores de densidade do açúcar líquido invertido controle e irradiado em diferentes doses em acelerador de elétrons.

\begin{tabular}{c|c|c|c|c}
\hline & $\begin{array}{c}\text { Graus de } \\
\text { liberdade }\end{array}$ & SQ & QM & F \\
\hline Doses & 5 & 0,000235 & 0,000047 & 40057,46 \\
\hline Resíduos & 12 & 0,000000 & 0,000000 & - \\
\hline Total & 17 & 0,000235 & - & - \\
\hline
\end{tabular}

$\mathrm{F}_{\mathrm{c}}(5,12, \alpha=5 \%)=3,11 ; \mathrm{SQ}=$ soma dos quadrados; $\mathrm{QM}=$ quadrado médio.

TABELA 26 - Análise de variância (ANOVA) para os valores de densidade do açúcar líquido invertido controle e irradiado em diferentes doses em fonte de cobalto- 60 .

\begin{tabular}{c|c|c|c|c}
\hline & $\begin{array}{c}\text { Graus de } \\
\text { liberdade }\end{array}$ & SQ & QM & F \\
\hline Doses & 5 & 0,000041 & 0,000008 & 204109,0 \\
\hline Resíduos & 12 & 0,000000 & 0,000000 & - \\
\hline Total & 17 & 0,000041 & - & - \\
\hline
\end{tabular}

$\mathrm{F}_{\mathrm{c}}(5,12, \alpha=5 \%)=3,11 ; \mathrm{SQ}=$ soma dos quadrados; $\mathrm{QM}=$ quadrado médio.

TABELA 27 - Análise de variância (ANOVA) para os valores de sólidos solúveis ( $\left.{ }^{0} B r i x\right)$ do açúcar líquido invertido controle e irradiado em diferentes doses em acelerador de elétrons.

\begin{tabular}{c|c|c|c|c}
\hline & $\begin{array}{c}\text { Graus de } \\
\text { liberdade }\end{array}$ & SQ & QM & F \\
\hline Doses & 5 & 0,137631 & 0,027526 & 3,479769 \\
\hline Resíduos & 12 & 0,094924 & 0,007910 & - \\
\hline Total & 17 & 0,232555 & - & - \\
\hline
\end{tabular}

$\mathrm{F}_{\mathrm{c}}(5,12, \alpha=5 \%)=3,11 ; \mathrm{SQ}=$ soma dos quadrados; $\mathrm{QM}=$ Quadrado médio.

TABELA 28 - Análise de variância (ANOVA) para os valores de sólidos solúveis ( ${ }^{0}$ Brix) do açúcar liquido invertido controle e icradiado cm diferentes doses em fonte de sobaltu-60.

\begin{tabular}{c|c|c|c|c}
\hline & $\begin{array}{c}\text { Graus de } \\
\text { liberdade }\end{array}$ & SQ & QM & F \\
\hline Doses & 5 & 0,763095 & 0,152619 & 22,21333 \\
\hline Resíduos & 12 & 0,082447 & 0,006871 & - \\
\hline Total & 17 & 0,845542 & - & - \\
\hline
\end{tabular}

$\mathrm{F}_{\mathrm{c}}(5,12, \alpha=5 \%)=3,11 ; \mathrm{SQ}=$ soma dos quadrados; $\mathrm{QM}=$ quadrado médio.

TABELA 29 - Análise de variância (ANOVA) para os valores de pH do açúcar líquido invertido controle e irradiado em diferentes doses em acelerador de elétrons.

\begin{tabular}{c|c|c|c|c}
\hline \multicolumn{5}{c}{ controle irradiado em diferentes doses em acelerador de eletrons. } \\
\hline & $\begin{array}{c}\text { Graus de } \\
\text { liberdade }\end{array}$ & SQ & QM & F \\
\hline Doses & 5 & 4,807294 & 0,961459 & 320,4863 \\
\hline Residuos & 12 & 0,036 & 0,003000 & \\
\hline Total & 17 & 4,843294 & & \\
\hline
\end{tabular}

$\mathrm{F}_{\mathrm{c}}(5,12, \alpha=5 \%)=3,11 ; \mathrm{SQ}=$ soma dos quadrados; $\mathrm{QM}=\mathrm{Quadrado}$ médio. 
TABELA 30 - Análise de variância (ANOVA) para os valores de pH do açúcar líquido invertido controle e irradiado em diferentes doses em fonte de cobalto- 60 .

\begin{tabular}{c|c|c|c|c}
\hline & $\begin{array}{c}\text { Graus de } \\
\text { liberdade }\end{array}$ & SQ & QM & F \\
\hline Doses & 5 & 4,304183 & 0,860837 & 209,6761 \\
\hline Resíduos & 12 & 0,049267 & 0,004106 & - \\
\hline Total & 17 & 4,35345 & - & - \\
\hline
\end{tabular}

$\mathrm{F}_{\mathrm{c}}(5,12, \alpha=5 \%)=3,11 ; \mathrm{SQ}=$ soma dos quadrados; $\mathrm{QM}=$ quadrado médio.

TABELA 31 - Análise de variância (ANOVA) para os valores de umidade pelo método de Kart Fischer do açúcar líquido invertido controle e irradiado em diferentes doses em acelerador de elétrons.

\begin{tabular}{c|c|c|c|c}
\hline & $\begin{array}{c}\text { Graus de } \\
\text { liberdade }\end{array}$ & SQ & QM & F \\
\hline Doses & 5 & 0,464273 & 0,092855 & 1,274526 \\
\hline Resíduos & 12 & 0,874251 & 0,72854 & - \\
\hline Total & 17 & 1,338524 & - & - \\
\hline
\end{tabular}

$\mathrm{F}_{\mathrm{c}}(5,12, \alpha=5 \%)=3,11 ; \mathrm{SQ}=$ soma dos quadrados; $\mathrm{QM}=$ Quadrado médio.

TABELA 32 - Análise de variância (ANOVA) para os valores de umidade, pelo método de Karl Fischer, do açúcar líquido invertido, controle e irradiado, em diferentes doses em fonte de cobalto-60.

\begin{tabular}{c|c|c|c|c}
\hline & $\begin{array}{c}\text { Graus de } \\
\text { liberdade }\end{array}$ & SQ & QM & F \\
\hline Doses & 5 & 3,268817 & 0,653763 & 9,190639 \\
\hline Resíduos & 12 & 0,853603 & 0,071134 & - \\
\hline Total & 17 & 4,12242 & - & - \\
\hline
\end{tabular}

$\mathrm{F}_{\mathrm{c}}(5,12, \alpha=5 \%)=3,11 ; \mathrm{SQ}=$ soma dos quadrados; $\mathrm{QM}=$ quadrado médio

TABELA 33 - Análise de variância (ANOVA) para os valores de umidade pelo método do índice de refração do açúcar líquido invertido controle e irradiado em diferentes doses em acelerador de elétrons.

\begin{tabular}{c|c|c|c|c}
\hline & $\begin{array}{c}\text { Graus de } \\
\text { liberdade }\end{array}$ & SQ & QM & F \\
\hline Doses & 5 & 0,210740 & 0,042148 & 10,89097 \\
\hline Resíduos & 12 & 0,046440 & 0,003870 & - \\
\hline Total & 17 & 0,25718 & - & - \\
\hline
\end{tabular}

$\mathrm{F}_{\mathrm{c}}(5,12, \alpha=5 \%)=3,11 ; \mathrm{SQ}=$ soma dos quadrados; $\mathrm{QM}=$ Quadrado médio.

TABELA 34 - Análise de variância (ANOVA) para os valores de umidade pelo método do índice de refração do açúcar líquido invertido, controle e irradiado, em diferentes doses em fonte de cobalto-60.

\begin{tabular}{c|c|c|c|c}
\hline & $\begin{array}{c}\text { Graus de } \\
\text { liberdade }\end{array}$ & SQ & QM & F \\
\hline \hline Doses & 5 & 0,444421 & 0,088884 & 24,27452 \\
\hline Resíduos & 12 & 0,043940 & 0,003662 & - \\
\hline Total & 17 & 0,488361 & - & - \\
\hline
\end{tabular}

$\mathrm{F}_{\mathrm{c}}(5,12, \alpha=5 \%)=3,11 ; \mathrm{SQ}=$ soma dos quadrados; $\mathrm{QM}=$ quadrado médio. 
TABELA 35 - Análise de variância (ANOVA) para os valores de sacarose do açúcar líquido invertido controle e irradiado em diferentes doses em acelerador de clétrons.

\begin{tabular}{c|c|c|c|c}
\hline & $\begin{array}{c}\text { Graus de } \\
\text { liberdade }\end{array}$ & SQ & QM & F \\
\hline Doses & 5 & 77,03194 & 15,40639 & 17,05322 \\
\hline Residuos & 12 & 10,84116 & 0,90343 & - \\
\hline Total & 17 & 87,8731 & - & - \\
\hline
\end{tabular}

$F_{c}(5,12, \alpha=5 \%)=3,11 ; \mathrm{SQ}=$ soma dos quadrados; $\mathrm{QM}=$ Quadrado médio.

TABELA 36 - Análise de variância (ANOVA) para os valores de açúcares redutores do açúcar líquido invertido controle e irradiado em diferentes doses em acelerador de elétrons.

\begin{tabular}{c|c|c|c|c}
\hline & $\begin{array}{c}\text { Graus de } \\
\text { liberdade }\end{array}$ & SQ & QM & F \\
\hline Doses & 5 & 53,44591 & 10,68918 & 19,53222 \\
\hline Resíduos & 12 & 6,56711 & 0,54726 & \\
\hline Total & 17 & 60,01302 & & \\
\hline
\end{tabular}

$\mathrm{F}_{\mathrm{c}}(5,12, \alpha=5 \%)=3,11 ; \mathrm{SQ}=$ soma dos quadrados; $\mathrm{QM}=$ Quadrado médio.

TABELA 37 - Análise de variância (ANOVA) para os valores de sacarose do acúcar líquido invertido controle e irradiado em diferentes doses em fonte de cobalto 60 .

\begin{tabular}{c|c|c|c|c}
\hline & $\begin{array}{c}\text { Graus de } \\
\text { liberdade }\end{array}$ & SQ & QM & F \\
\hline Doses & 5 & 29,2438 & 5,848769 & 14,76342 \\
\hline Resíduos & 12 & 4,75399 & 0,396166 & - \\
\hline Total & 17 & 33,99779 & - & - \\
\hline
\end{tabular}

$\mathrm{F}_{\mathrm{c}}(5,12, \alpha=5 \%)=3,11 ; \mathrm{SQ}=$ soma dos quadrados; $\mathrm{QM}=$ quadrado médio.

TABELA 38 - Análise de variância (ANOVA) para os valores de cor do açúcar líquido invertido controle e irradiado em diferentes doses em acelerador de elétrons.

\begin{tabular}{c|c|c|c|c}
\hline & $\begin{array}{c}\text { Graus de } \\
\text { liberdade }\end{array}$ & SQ & QM & F \\
\hline Doses & 5 & 7476,678 & 1495,336 & 189,6526 \\
\hline Resíduos & 12 & 94,615 & 7,885 & - \\
\hline Total & 17 & 7571,293 & - & - \\
\hline
\end{tabular}

$\mathrm{F}_{\mathrm{c}}(5,12, \alpha=5 \%)=3,11 ; \mathrm{SQ}=$ soma dos quadrados; $\mathrm{QM}=$ Quadrado médio.

TABELA 39 - Análise de variância (ANOVA) para os valores de cor do açúcar líquido invertido controle e irradiado em diferentes doses em fonte de cobalto- 60 .

\begin{tabular}{c|c|c|c|c}
\hline & $\begin{array}{c}\text { Graus de } \\
\text { liberdade }\end{array}$ & SQ & QM & F \\
\hline Doses & 5 & 2478,474 & 495,6948 & 2680,029 \\
\hline Resíduos & 12 & 2,22 & 0,1850 & - \\
\hline Total & 17 & 2480,694 & - & - \\
\hline
\end{tabular}

$\mathrm{F}_{\mathrm{c}}(5,12, \alpha=5 \%)=3,11 ; \mathrm{SQ}=$ soma dos quadrados; $\mathrm{QM}=$ Quadrado médio. 
TABELA 40 - Análise de variância (ANOVA) para os valores de hidroximetilfurfural do açúcar líquido invertido controle e irradiado em diferentes doses em acelerador de elétrons.

\begin{tabular}{c|c|c|c|c}
\hline & $\begin{array}{c}\text { Graus de } \\
\text { liberdade }\end{array}$ & $\begin{array}{c}\text { Soma dos } \\
\text { quadrados }\end{array}$ & $\begin{array}{c}\text { Quadrado } \\
\text { médio }\end{array}$ & $F$ \\
\hline Doses & 5 & 1398,300 & 279,6600 & 50,66422 \\
\hline Resíduos & 12 & 66,238 & 5,5199 & - \\
\hline Total & 17 & 1464,538 & - & - \\
\hline
\end{tabular}

$F_{c}(5,12, \alpha=5 \%)=3,11 ; S Q=$ soma dos quadrados; $Q M=$ Quadrado médio.

TABELA 41 - Análise de variância (ANOVA) para os valores de hidroximetilfurfural do açúcar líquido invertido controle e irradiado em diferentes doses em fonte de cobalto-60.

\begin{tabular}{c|c|c|c|c}
\hline & $\begin{array}{c}\text { Graus de } \\
\text { liberdade }\end{array}$ & SQ & QM & F \\
\hline Doses & 5 & 848,2646 & 169,6529 & 27,47745 \\
\hline Resíduos & 12 & 74,0911 & 6,1743 & - \\
\hline Total & 17 & & - & - \\
\hline
\end{tabular}

$\mathrm{F}_{\mathrm{c}}(5,12, \alpha=5 \%)=3,11 ; \mathrm{SQ}=$ soma dos quadrados; $\mathrm{QM}=$ quadrado médio.

TABELA 42 - Análise de variância (ANOVA) para os valores de viscosidade do açúcar líquido invertido controle e irradiado em diferentes doses em acelerador de elétrons.

\begin{tabular}{c|c|c|c|c}
\hline & $\begin{array}{c}\text { Graus de } \\
\text { liberdade }\end{array}$ & $\begin{array}{c}\text { Soma dos } \\
\text { quadrados }\end{array}$ & $\begin{array}{c}\text { Quadrado } \\
\text { médio }\end{array}$ & F \\
\hline Doses & 5 & 600911,1 & 120182,2 & 599,9705 \\
\hline Resíduos & 24 & 4807,5 & 200,3 & - \\
\hline Total & 29 & 605718,6 & - & - \\
\hline
\end{tabular}

$\mathrm{F}_{\mathrm{c}}(5,24, \alpha=5 \%)=2,62 ; \mathrm{SQ}=$ soma dos quadrados; $\mathrm{QM}=$ Quadrado médio.

TABELA 43 - Análise de variância (ANOVA) para os valores de viscosidade do açúcar líquido invertida. controle e irrudiado en diferenfex dases em fonte the cobullo-60.

\begin{tabular}{c|c|c|c|c}
\hline & $\begin{array}{c}\text { Graus de } \\
\text { liberdade }\end{array}$ & SQ & QM & F \\
\hline Doses & 5 & 392944,4 & 78588,8 & 7,258424 \\
\hline Resíduos & 84 & 909490,3 & 10827,26 & - \\
\hline Total & 89 & 1302434,7 & - & - \\
\hline
\end{tabular}

$\mathrm{SQ}=$ soma dos quadrados; $\mathrm{QM}=\mathrm{Quadrado}$ médio. 


\section{REFERÊNCIAS BIBLIOGRÁFICAS}

ADAM, S. Recent developments in radiation chemistry of carbohydrates. In: ELIAS, P.S.; COHEN, A.J., eds. Recent advances in food irradiation. Amsterdam, New York: Elsevier Biomedical Press, 1983. p. 149-170.

ALISTE, A.J.; VIEIRA, F.F.; DEL MASTRO, N.L. Radiation effects on agar, alginates and carrageenan to be used as food additives. Radiation Physics and Chemistry, v.57, p. 305-308, 2000

ALISTE, A.J.; DEL MASTRO, N.L. Ascorbic acid as radiation protector on polysaccharides used in food industry. Colloids and Surfaces, A: Physicochemical and Engineering. Aspects, v.249, p. 131-133, 2004.

AQUINO, S. Efeitos da radiação gama no crescimento de Aspergillus flavus produtor de aflatoxinas e no emprego da técnica da Reação em Cadeia da Polimerase (PCR) em amostras de grãos de milho inoculadas artificialmente. São Paulo, 2003. 85p. Dissertação de Mestrado - Instituto de Pesquisas Energéticas e Nucleares.

ASSOCIAÇÃO BRASILIERIA DE NORMAS TÉCNICAS. Apresentação de citação em documentos: procedimento. Rio de Janeiro: ABNT, 1993. (NBR 12995).

ASSOCIATION OF OFFICIAL ANALYTICAL CHEMISTS. Official methods of analysis of AOAC International. Gaithersburg: AOAC International, 2000. 44.1.04C.

AZIZ, N.H.; MOUSSA, A.A. Influence of gamma-radiation on mycotoxin producing moulds and mycotoxins in fruits. Food Control, v.13, p.281-288, 2002.

BARA, D. Effect of gamma radiation on D-glucose present in aplle juice. Journal of Food Science, v.38, p.108-111, 1973.

BARKER, S.A.; GRANT, P.M.; STACEY, M.; WARD, R.B. Efects of $\gamma$-radiation. I. Polymer formation from sugars, hydroxy acids, and amino-acids. Journal of the Chemical Society, p.2648-2654, jun.-oct., 1959.

BERRY, R.J.; HILLS, P.R.; TRILLWOOD, W. Demonstration of a cytotoxic agent in gamma-irradiated carbohydrate solutions. International Journal of Radiation Biology, v.9, n.6, p.559-572, 1965.

BOBBIO, P.A.; BOBBIO, F.O. Química do processamento de alimentos. São Paulo, S.P.: 3.ed.Livraria Varela, 2001. 
BOTHNER-BY, C.T.; BALAZS, E.A. Effect of ionizing radiations on glucose solutions. Radiation Research, v.6, p.302-317, 1957.

BRASIL. Ministério da Saúde. Agência Nacional de Vigilância Sanitária. Legislação. VisaLegis. Decreto n.72718, de 29 de agosto de 1973. Dispõe sobre normas gerais para a irradiação de alimentos. Disponivel em: http.ilelegis.anvisa.gov br/leisref/public/showAct.php?id=25\&word=. Acesso em: 03 jun. 2006.

BRASIL. Ministério da Saúde. Secretaria Nacional de Vigilância Sanitária. Divisão Nacional de Vigilância Sanitária de Alimentos. Portaria n.9, de 08 de março de 1985. Diário Oficial da União, Brasília, 13 de março de 1985. Seção 1.

BRASIL. Divisão Nacional de Vigilância Sanitária de Alimentos, da Secretaria Nacional de Vigilância Sanitária do Ministério da Saúde. Portaria n.30, de 25 de setembro de 1989. Diário Oficial da União, Brasília, 28 de setembro de 1989. Seção 1.

BRASIL. Ministério da Saúde. Agência Nacional de Vigilância Sanitária. Legislação. VisaLegis. Resolução RDC n.21, de 26 de janeiro de 2001. Disponível em: http://elegis.anvisa gov.br/leisref/public/showAct.php?id=161\&word=. Acesso em: 03 jan. 2006.

BRASIL. Ministério da Saúde. Agência Nacional de Vigilância Sanitária. Legislação. VisaLegis. Resolução RDC n.271, de 22 de setembro de 2005. Disponível em: http.//elegis.bvs.br/leisref/public/showAct.php?id=18830\&word=. Acesso em: $10 \mathrm{mar}$. 2007.

BRUDER, F.; MOROZ, R.D. Production of liquid sugar from raw sugar. Sugar y Azucar, v.76, n.3, p.34-40, 1981.

BYRNE, M. Irradiation update. Food Engineering International, v.21, n.6, p.37-41, 1996.

BYUN, M.W., KANG, I.J.; MORI, T. Effect of $\gamma$-irradiation on the water soluble components of soybeans. Radiation Physics and Chemistry, v.47, n.1, p.155-160, 1996.

CAMARGO, R.J. Estudo do tratamento combinado de radiação ionizante e cobertura de quitosana em mamão Papaia (Carica papaya L.). São Paulo, 2004. 130p. Dissertação de Mestrado - Instituto de Pesquisas Energéticas e Nucleares.

CHEMELLO, E. A química na cozinha apresenta: o açúcar. 2005. Disponível em: http:/www ciadaescola com br/zoom/materia asp?materia $=291$ \&pagina=6. Acesso em: 25. nov. 2006.

CRAWFORD, L.M.; RUFF, E.H. A review of the safety of cold pasteurization through irradiation. Food Control, v.7, n.2, p.87-97, 1996. 
DAVIS, P.R.; PRINCE, R.N. Liquid sugar in the food industry: use of sugars and other carbohydrates in the food industry. Washington: American Chemical Society, 1955. p.35-42. (Advances in chemistry series).

DEEBLE, D.J.; PHILLIPS, G.O.; BOTHE, E.; SCHUCHMANN, H.P.; SONNTAG, V.C. The radiation-induced degradation of hyaluronic acid. Radiation Physics and Chemistry, v.37, n.1, p.115-118, 1991.

DEELEY, C.M. A basic interpretation of the technical language of radiation processing. Radiation Physics and Chemistry, v.71, p.503-507, 2004.

DEL MASTRO, N.L. Development of food irradiation in Brazil. Progress in Nuclear Energy, v.35, n.3/4, p.229-248, 1999.

DELINCÉÉ, H. Detection of food treated with ionizing radiation. Trends in Food Science \& Technology, v.9, p.73-82, 1998.

DEMIATE, I.M.; WOSIACKI,G.; CZELUSNIAK,C.; NOGUEIRA, A. Determinação de açúcares redutores e totais em alimentos. Comparação entre método colorimétrico e titulométrico. Ciências Exatas e da Terra, Ciências Agrárias e Engenharia, v. 8, n.1, p. $65-78,2002$.

DESROSIER, N.W.; ROSENSTOCK, H.M. Radiation technology in food, agriculture and biology. Westprot: AVI Publishing, 1960. 401p.

DIEHL, J.F.; ADAM, S.; DELINCÉE, H.; JAKUBICK, V. Radiolysis of carbohydrates and of carbohydrate-containing foodstuffs. Journal of Agricultural and Food Chemistry, v.26, n.1, p.15-20, 1978.

DIEHL, J.F. Food irradiation-past, present, and future. Radiation Physics and Chemistry, v.63, p.211-215, 2002.

DITTMAR, J.H. Hygroscopicity of sugars and sugar mixtures. Journal of Industrial and Engineering Chemistry, v.27, n.3, p.333-335, 1935.

DRIJVER, L.D.; HOLZAPFEL, C.W. Separation and quantitative determination of the radiolysis products of D-fructose as their O-Benzyloximes. Journal of Chromatography, v.363, p.345-352, 1986.

EHLERMANN, D.A.E. Food irradiation. In: SPIESS, W.E.L.; SCHUBERT, H., eds. Engineering and Food: preservation process and related techniques. London: Elsevier Applied Science, 1990. v.2, p.25-40. (Proceedings of the fifth International Congress on Engineering and Food held 1989, Cologne, Germany). 
FALLICO, B.; ZAPPALÁ, M.; VERZERA, A.A. Effects of conditioning on HMF content in unifloral honeys. Food Chemistry, v.85, p.305-313, 2004.

FARKAS, J. Irradiations for better foods. Trends in Food Science \& Technology, v.17, p. 148-152, 2006.

FERREIRA, V.L.P.; ALMEIDA, T.C.A.; PETTINELLI, M.L.C.V.; SILVA, M.A.A.P.; CHAVES, J.B.P.; BARBOSA, E.M.M. Análise Sensorial Testes Discriminativos e Afetivos. SBCTA, 2000.

FOOD AND AGRICULTURAL ORGANIZATION OF THE UNITED NATIONS. FAOSTAT. Production. Disponível em: http://fáostat fao org/site/567/DesktopDefault aspx?PageID=567. Acesso em: 7.dez.2006.

GONZALES, A.P.; BURIN, L.; BUERA, M.P. Color changes during storage of honeys in relation to their composition and initial color. Food Research International, v.32, n.3, p.185-191, 1999.

GRANT, P.M; WARD, R.B. Effects of $\gamma$-radiation Part IV The degradation of D-glucose in aqueous solution by $\gamma$-irradiation in vacuo. Journal of the Chemical Society, p.28712876, sept.-oct. 1959.

GRATÃO, A.C.A.; BERTO, M.I.; SILVEIRA Jr., V. Reologia do açúcar líquido invertido: influência da temperatura na visçosidade. Ciência e Tecnologia de Alimentos, v.24, n.4, p.652-656, 2004.

GRAY, J,; MOWER, H.F. The role of simple carbohydrates in the suppression of hydroxyl free radical in $\gamma$-irradiated papaya juice. Food Chemistry, v.41, n.3, p.293-301, 1991.

GROVES, R. Inversion, invert sugar and invertase. Candy Industry, v.163, pt.10, p.18, 1998.

GRÜNEWALD, T. Electron irradiation of dry food products. Radiation Physics and Chemistry, v.22, n.3/5, p.733-741, 1983.

HACKWOOD, S. An introduction of the irradiation processing of foods. In: THORNE, S., ed. Food irradiation. New York: Elsevier Science Publishers LTD, 1991. p.54-65.

HENON, Y.M. Food irradiation in perspective. Radiation Physics and Chemistry, v.46, n.4/6, p.647-651, 1995. (Proceedings of the $9^{\text {th }}$ International Meeting on Radiation Processing, 1994, pt.1).

HFCS FACTS. Disponível em: http://wwwhfesfacts.com/. Acesso em: 07 jun. 06. 
HODGE, J.E. Chemistry of browning reactions in model systems. Agricultural and Food Chemistry, v.1, n.15, p.928-943, 1953.

HOWARD, D.W. A look at viscosity. Food Technology, v.48, n.7, p.82-84, 1991.

INSTITUTO ADOLFO LUTZ. Normas analíticas do Instituto Adolfo Lutz: metódos físico-químicos para análise de alimentos. Brasília: ANVISA, 2005. v.1, 1018p.

INTERNATIONAL CONSULTIVE GROUP ON FOOD IRRADIATION. Training manual on operation of food irradiation facilities. Vienna: ICGFI, 1992. (Documento, n.14).

JOSEPHSON, E.S.; PETERSON, M.S. Preservation of food by ionizing radiation. Boca Raton: CRC Press, 1983. v.2, 343p.

JUNK, W.R.; NELSON, O.M.; SHERRILL, M.H. Liquid sugar in food products. Food Technology, v.1, p.506-518, 1947.

KATAYAMA, T; NAKAUMA, M; TODORIKI, S.; PHILLIPS, G.O.; TADA, M. Radiation-induced polymerization of gum arabic (Acacia senegal) in aqueous solution. Food Hydrocolloids, v.20, n.7, p.983-989, 2006.

KILCAST, D. Food Irradiation: current problems and future potential. International Biodeterioration and Biodegradation, v.36, n.3/4, p.279-296, oct.-dez., 1995.

LAGUNAS-SOLAR, M.C.; MATTHEWS, S.M. Radionuclide and electric accelerator sources for food irradiation. Radiation Physics and Chemistry, v.25, n.4/6, p.691-702, 1985.

LEAL, A.S.; KRAMBROCK, K.; GUEDES, K.; RODRIGUES, R.R. Ressonância paramagnética eletrônica-RPE aplicada à análise de especiarias irradiadas (com radiação gama). Ciência e Tecnologia de Alimentos, v.24, n.3, p.427-430, 2004.

LEPKI, L.F.S.F. Efeito da radiação ionizante na viscosidade do ovo industrializado. São Paulo, 1998. 70p. Dissertação de Mestrado - Instituto de Pesquisas Energéticas e Nucleares.

LIGGETT, R.W.; DEITS, V.R. Color and turbidity of sugar products. Advances in Carbohydrate Chemistry, v.9, p.247-284, 1954.

LIGGETT, R.W.; FEAZEL, C.E.; ELEENBERG, J.Y. Browning reaction initiated by gamma irradiation. Journal of Agricultural and Food Chemistry, v.7, n.4, p.277-280, 1959. 
LOAHARANU, P. Status of food irradiation worldwide. Preharambeno-Technol. Biotechnol., v.30, n.4, p.131-134, 1992.

LOAHARANU, P. Cost/benefit aspects of food irradiation. Food Technology, v.48, n.1, p.104-108, 1994.

MARIGNETTI, M.; MANTOVANI, G. Liquid sugar. Sugar Technology Reviews, v.7, p.3-47, 1979/80.

MENDOZA, M.R.; SANZ, M.L.; OLANO, A.; VILLAMICL, M. Formation of hydroxymethylfurfural and furosine during the storage of jams and fruit-based infant foods. Food Chemistry, v.85, p.605-609, 2004.

MOROZ, R.D.; SULLIVA, J.P.; TROY, J.P.; BROEG, C.B. Levulose and invert sugars. Sugar y Azucar, v.68, n.8, p.46-52, 1973.

MOY, J.H. Low dose irradiation of foods-prospects and problems. In: LE MAGUER, M.; JELEN, P., eds. Food engineering and process applications: transport phenomena. New York: Elsevier Applied Science, 1986. v.1, p.4-16. (Proceedings of the fourth International Congress on Engineering and Food, held between $7^{\text {th }}$ and $10^{\text {th }}$ July 1985 at Edmonton, Alberta, Canada).

MOY, J.H. Irradiation processing of fruits and vegetables, status and prospects. In: JEN, J.J., ed. Quality factors of fruits and vegetables: chemistry and technology. Washington: American Chemical Society, 1989. (ACI Symposium Series, 97).

MUÑOZ, R.B.; SANCHEZ, M.V.; UZCATEGUI, E.A.; VACA, C.F. Preservación de alimentos por irradiación. Quito: Escuela Politécnica Nacional, 1985. 350p.

N. RAICA, J.; SCOTT, J; Nielsen, W. The nutricional quality of irradiated foods. Radiation Research Review, v. 3, p. 447-457, 1972.

OH, S.H.; LEE, Y.S.; LEE, J.W.; KIM, M.R.; YOOK, H.S.; BYUN, M.W. The effect of $\gamma-$ irradiation on the non-enzymatic browning reaction in aqueous model solutions. Food Chemistry, v.92, n.2, p.357-363, 2004.

OH, S.H; LEE, Y.S; KIM, J.H.; KIM, J.H.; LEE,J.W.; KIM, M.R.; YOOK, H.S.; BYUN, M.W. Effects of $\mathrm{pH}$ on non-enzymatic browning reaction during $\gamma$-irradiation processing using sugar and sugar-glycine solution. Food Chemistry, v.94, p.420-427, 2006.

OLIVEIRA, I.B.; SABATO, S.F. Dissemination of the food irradiation process on different opportunities in Brazil. Radiation Physics and Chemistry, v.71, p.493-497, 2004 
O'MAHONY, M., Sensory Evaluation of food-Statistical Methods and Procedures, Marcel Dekker, inc. New York, 1986.

PASCHOALIM, S.A.C. Contribuição ao estudo da hidrólise enzimática da sacarose por células de Saccharomyces cerevisae (levedura de panificação). São Paulo, 1990. 67p. Dissertação de Mestrado - Escola Politécnica - Universidade de São Paulo.

PAVIA, D.L; LAMPMAN, G.M.; KRIZ, G.S. Introduction to spectroscopy: a guide for students of organic chemistry. 2.ed. Forth Worth: Harcourt Brace College, 1996. $511 \mathrm{p}$.

PHILLIPS, G.O. Radiation chemistry of carbohydrate systems. Advances in Carbohydrate Chemistry, v.16, p.13-58, 1961.

PHILLIPS, G.O. Effects of ionizing radiations on carbohydrate systems. Radiation Research Reviews, v.3, p.335-351, 1972.

RANKEN, M.D.; KLLL, R.C.; BAKER, C. Food industries manual. 23.ed. London: Chapman \& Hall, 1993. 650p.

RODRIGUES, M.V.N.; RODRIGUES, R.A.F.; SERRA, G.E; ANDRIETTA, S.R; FRANCO, T.T. Produção de xarope de açúcar invertido obtido por hidrólise heterogênea, através de planejamento experimental. Ciência e Tecnologia dé Alimentos, v.20, n.1 p. $103-109,2000$.

SABATO, S.F.; LACROIX, M. Radiation effects on viscosimetry of protein based solutions. Radiation Physics and Chemistry, v.63, p.357-359, 2002.

SANTOS, W.M. Aplicação de viscosimetria na deteç̧ão de especiarias irradiadas. São Paulo: 2004. 72p. Dissertação de Mestrado - Instituto de Pesquisas Energéticas e Nucleares.

SANZ, M.L.; CASTILLO, M.D.; CORZO, N.; OLANO, A. 2-furoylmethyl amino acids and hydroxymethylfurfural as indicators of honey quality. Journal of Agricultural and Food Chemistry, v.51, p.4271-4283, 2003.

SCHERZ, H. Formation of deoxycompounds and malondialdehyde in irradiated aqueous solutions of carbohydrates and related compounds. Radiation Resarch, v.43, p.12-24, 1970.

SCHWARZ, H.A. Free radicals generated by radiolysis of aqueous solution. Journal of Chemical Education, v.58, n.2, p.101-105, 1981.

SHALLENBERGER, R.S.; BIRCH, G.G. Sugar Chemistry. Westport, Connecticut: The Avi Publishing Company, INC, 1975. 
SLLVA, N.; JUNQUEIRA, V.C.A.; SILVEIRA, N.F.A. Manual de métodos de análise microbiológica de alimentos. 2. ed. São Paulo: Varela, 2001. p.21-29.

SNELL, J.B. Polymer production from aqueous solutions of D-glucose by high energy radiation. Journal of Polymer Science, Part A: General Papers, v.3, n.7, p.2591-2607, 1965.

SONNTAG, C.V. Free-radical reactions of carbohydrates as studied by radiation techniques. Advances in Carbohydrate Chemistry and Biochemistry, v.3, p.7-74, 1980.

SOUZA, M.D.C.A. Efeito da radiação gama sobre a aguardente de cana-de-açúcar. São Paulo, 2000. 104p. Dissertação de mestrado - Instituto de Pesquisas Energéticas e Nucleares.

STEVENSON, M.H; STEWART, E.M. Identification of irradiated food: the current ststus. Radiation Physics and Chemistry, v.46, n.4/6, p.653-658, 1995.

STOTHER, B. UV disinfection in liquid sugar manufacture. International Sugar Journal, v.101, n. 1207, p.361-363, 1999.

Sweet but not so innocent? Disponivel em: http://www washingtonpost.com/ac2/wp= dyn/A8003-2003 Mar102language=printer. Acesso em: 07 jun. 06.

THAKUR, B.R., SINGH, R.K. Combination processes in food irradiation. Trends in Food Science \& Technology, v.6, n.1, p.7-11, 1995.

TOSI, E.; CIAPPINI, M.; RÉ, E; LUCERO, H. Honey therma treatments effects on hydroxymethylfurfural content. Food Chemsitry, v.77, p.71-74, 2002.

ULANSKI, P.; ROSIAK, J. Preliminary studies on radiation-induced changes in chitosan. Radiation Physics and Chemistry, v.39, n.1, p.53-57, 1992.

VIEIRA, F.F.; DEL MASTRO, N.L Comparison of $\gamma$-radiation and electron beam irradiation effects on gelatin. Radiation Physics and Chemistry, v.63, p.331-332, 2002.

VILLAVICENCIO, A.L.C.H. Avaliação dos efétês da radiação ionizante de ${ }^{60} \mathrm{Co}$ em propriedades físicas, químicas e nutricionais dos feijões Phaseolus vulgaris L. e Vigna unguiculata (Lo) Walp. São Paulo, 1998. 138p. Tese de Doutorado - Faculdade de Ciências Farmacêuticas - Universidade de São Paulo.

WAISIKIEWICZ; J.M; YOSHII, F.; NAGASAWA, N.; WACH, R.A.; MITOMO, H. Degradation of chitosan and sodium alginate by gamma radiation, sonochemical and ultraviolet methods. Radiation Physics and Chemistry, v.73, n.5, p.287-295, 2005. 
WORLD HEALTH ORGANIZATION; WORLD ORGANIZATION EXPERT COMMITTEE. La comestibilidade de los alimentos irradiados: report of a joint Food and Agriculture Organization; International Atomic Energy. Geneva: World Health Organization, 1977. (Technical report series, 604).

WORLD HEALTH ORGANIZATION; FOOD AND AGRICULTURE ORGANIZATION OF THE UNITED NATIONS; INTERNATIONAL ATOMIC ENERGY AGENCY. Wholesomeness of irradiated food: report of a joint FAO/IAEA,WHO Expert Committee. Geneva: World Health Organization, 1981. 34p. (Technical report series, 659).

WUNDERLIN, D.A.; PESCE, S.F; AMÉ, M.V.; FAYE, P.F. Decomposition of hidroxymethylfurfural in solution and protective effect of fructose. Journal of Agricultural and Food Chemistry, v.46, p. 1855-1863, 1998.

Xu, H.; TEMPLETON, A.C.; REED, R.A. Quantification of 5-HMF and dextrose in commercial aqueous dextrose solutions. Journal of Pharmaceutical and Biomedical Analysis, v.32, p.451-459, 2003.

YU, H.; SABATO, S.F.; D'APRANO, G.; LACROIX, M. Effect of the addition of CMC on the aggregation behaviour of proteins. Radiation Physics and Chemistry, v.71, p.129$133,2004$. 